\title{
LEGAL MATERIALS
}


B.S. Chimni - 9789047408253

Downloaded from Brill.com04/26/2023 12:04:14PM via free access 


\section{STATE PRACTICE OF ASIAN COUNTRIES IN THE FIELD OF INTERNATIONAL LAW*}

\section{BANGLADESH ${ }^{1}$}

Bangladesh has recently enacted the Arbitration Act 2001 (the Act). It came into force on 10 April 2001, ${ }^{2}$ repealing the Arbitration (Protocol and Convention) Act 1937 and the Arbitration Act $1940,{ }^{3}$ legacies of the British Raj in India. Such a legislative step was urgent in the face of increasing foreign investment in Bangladesh in various sectors, especially in natural gas and power, and the ever-growing export trade with the rest of the world. The Act, principally based on the UNCITRAL Model Law, ${ }^{4}$ consolidates the law relating to both domestic and international commercial arbitration. It thus creates a single and unified legal regime for arbitration in Bangladesh. This modernization gives Bangladesh a facelift as an attractive place for dispute resolution in the field of international trade, commerce and investment.

The Act has 59 sections organized into 14 chapters. Chapter I (s1) deals with introductory matters; Chapter II (ss2-8), general provisions; Chapter III (ss9-10), the arbitration agreement; Chapter IV (ss11-16), composition of the tribunal; Chapter V (ss17-22), jurisdiction of arbitral tribunals; Chapter VI (ss23-35), conduct of proceedings; Chapter VII (ss36-41), the making of the award and termination of proceedings; Chapter VIII (ss42-43), recourse against an award; Chapter IX (s44), enforcement of awards; Chapter X (ss45-47), recognition and enforcement of certain foreign awards; Chapter IX (s48), appeals; Chapter XII (ss49-56), miscellaneous (deposit of costs, dispute as to arbitrator's remuneration or costs, bankruptcy, limitations, etc.); Chapter XIII (ss57-58), supplementary provisions (power of the Govern-

\footnotetext{
* Edited by B.S. Chimni. However, the responsibility for the veracity of the materials included is that of the individual contributors alone.

${ }^{1}$ Contributed by A.F.M. Maniruzzaman, Professor of International and Business Law, University of Portsmouth, United Kingdom.

2 The official authentic English text has not yet been published.

3 By s 59(1).

4 Available at http://www.uncitral.org/en-index.htm.
}

Asian Yearbook of International Law, Volume 10 (B.S. Chimni et al., eds.)

(C) 2005 Koninklijke Brill NV. Printed in The Netherlands, pp. 167-264. 
ment or of the Supreme Court to make rules), and Chapter XIV (s59), repeals and savings.

The salient features of the Act are:

a) The preamble specifically mentions that it is "[a]n Act to enact the law relating to international commercial arbitration, recognition and enforcement of foreign arbitral awards and other arbitrations." However, the Act is also applicable to domestic arbitration.

b) In an international commercial dispute one of the parties to the dispute must be either a firm registered abroad or a foreign national.

c) The dispute in question must arise out of a legal relationship, whether contractual or not, but considered as a commercial dispute under the law in force in Bangladesh.

d) The parties are free to determine the number of arbitrators. If they fail to do so, the tribunal is to consist of three.

e) The parties may choose arbitrators of any nationality and the chairman of the tribunal may be of any nationality if that factor is accepted by the parties.

f) The courts (i.e., the District Judge's Court in respect of domestic commercial arbitration and the High Court Division of the Supreme Court of Bangladesh in respect of international commercial arbitration) can intervene in regard to appointments of the arbitrators on behalf of the parties as well as of the chairman of the arbitral tribunal within sixty days from the receipt of a party's application, to facilitate the arbitral process.

g) The court shall respect the parties' agreement to arbitrate and refer any party to such agreement to arbitration and stay any legal proceedings that may have been commenced against the other party.

h) The parties are free to agree on the venue, failing which the tribunal shall determine it, having regard to the circumstances of the case, including the convenience of the parties.

i) In the absence of the parties' agreement as to the language of the proceedings, the tribunal can use any language it deems appropriate.

j) The Act preserves the doctrines of severability of the arbitration agreement and competence-compétence, so that the tribunal can rule on its own jurisdiction.

k) The tribunal is not bound to follow the Code of Civil Procedure 1908 or the Evidence Act 1872 . Subject to the parties' agreement, it may adopt any procedure for conducting the proceedings.

1) With respect to the substance of a dispute, the parties are free to choose the rules of law or legal system of any country. In the context of the substantive law chosen by the parties, the Act expressly discards renvoi, unless the parties agree to the contrary.

m) If the parties do not choose the applicable substantive law, the Act authorizes the tribunal to apply the rules of law - anything short of a legal system, such as transnational commercial rules or the rules of lex mercatoria - which the tribunal deems most appropriate in the circumstances.

n) If all the parties agree, the tribunal may use mediation, conciliation or any other procedure at any time during the arbitral proceedings to encourage settlement. 
o) Although the Act makes provision for the tribunal to make interim orders in respect of the subject-matter of the dispute, a similar provision has not been made for the court, whose intervention may still be needed in an emergency even before the tribunal is constituted.

p) No appeal lies against the tribunal's order of interim measure of protection.

q) The tribunal can summon any persons to appear before it, albeit through the competent court, to give evidence or to submit materials if they do not do so of their own accord.

r) The tribunal has no power to act in respect of consolidation of arbitral proceedings and concurrent hearings, unless it is given by the parties on agreed terms. The parties are free to agree on these matters.

s) The tribunal must deal with any dispute submitted to it as quickly as possible and act fairly and impartially by giving each party 'reasonable opportunity' to participate in the proceedings, and in deciding its procedure and evidence and in exercising other powers conferred upon it.

t) Subject to the parties' agreement, the tribunal may appoint experts, legal advisers or assessors to assist it on specific issues.

u) The tribunal may continue the proceedings in the absence of a party and make an award on the basis of the evidence before it.

v) The tribunal must make its award without undue delay and the award will have the same force of law as if it were a decree of a court.

w) An award shall be made by the majority of the arbitrators and shall be in writing and signed at least by the majority where the tribunal consists of more than one arbitrator.

x) An award can be challenged in the court only on specified grounds.

y) The Act makes provision for appeal against an order of the court setting aside or refusing to set aside an award, or refusing to recognize or enforce any foreign arbitral award. All these appeals go to the Appellate Division of the Supreme Court of Bangladesh. 


\title{
INDIA $^{5}$
}

\section{JUDICIAL DECISIONS}

\section{Maritime Liens and Maritime Claims under Indian Law vis-à-vis various related International Conventions - the extent of adaptations of these conventions into Indian law}

\author{
M.V. AL. QUAMAR v. TSAVLIRIS SALVAGE (INTERNATIONAL) LTD. AND \\ OTHERS
}

\section{Supreme Court of India, 17 August 2000 AIR 2000 Supreme Court 2826}

Facts

The Petitioner was the owner of the ship M.V. Al. Quamar. Respondent No. 1 company M/s Tsavliris Salvage (International) Ltd. had obtained a decree from the Admiralty Court in England against this ship pursuant to a contract of salvage entered into by it with Respondent No. 2 who was the owner of the ship at that point of time (the ship was named M.V. Al Tabish). Respondent No.1 Company had, pursuant to a Salvage Contract with Respondent No. 2, mobilized its tug for salvaging and towing the aforesaid vessel which had met rough weather in the high seas. The English Admiralty Court had passed the decree holding Respondent No. 2 liable. The money decree passed by the English Court was a decree in personam against Respondent No. 2. The ship in question was found located in the territorial waters of the state of Andhra Pradesh, India and consequently within the Admiralty Court of Andhra Pradesh, being the High Court of Andhra Pradesh, as a successor to the Chartered High Court of Madras. ${ }^{6}$ Respondent No. 1, decree-holder, having come to know about the anchoring of the said ship at Visakhapatnam (in the state of Andhra Pradesh in India) filed an execution petition invoking section 44A of the Indian Civil Procedure Code for the arrest and detention of the ship and for recovering the decretal amount from Respondent No. 2. ${ }^{7}$ The master of the ship (Petitioner, who is the

\footnotetext{
${ }^{5}$ Contributed by V.G. Hegde, Associate Professor, School of International Studies, Jawaharlal Nehru University, New Delhi.

${ }^{6}$ The Admiralty jurisdiction was a British legacy. The Court, while tracing the historical antecedents of this development noted, albeit briefly, “...This special admiralty jurisdiction was saved by the Government of India Act, 1915 as also that of 1935 and subsequently protected in terms of Article 225 of the Constitution". The Court further noted "...these three Presidency towns (Calcutta, Madras and Bombay) were conferred with the same jurisdiction as was vested in the High Court of England...". Article 225 of the Indian Constitution seeks to save the jurisdiction of the existing High Courts. It, inter alia, provides that “...shall be the same as immediately before the commencement of this Constitution".

7 Section 44A of the Indian Civil Procedure Code provides for the execution of decrees passed by courts in reciprocating territories which included the United Kingdom.
} 
present owner of the ship) challenged these execution proceedings before the Supreme Court. $^{8}$

State Practice and Implementation:

The Court, while referring to the concept and scope of application of maritime lien and claim, noted that India had not adapted into its legal system the Brussels Convention relating to the Arrest of Seagoing Ships, 1952. While on this issue, the Court repeated its general observations in the case of MV Elisabeth in 1993:

Indian legislation has not [...] progressed, notwithstanding the Brussels Protocol of 1968 adopting the Visby Rules or the United Nations Convention on the Carriage of Goods by Sea, 1978 adopting the Hamburg Rules. The Hamburg Rules prescribe the minimum liabilities of the carrier far more justly and equitably than the Hague Rules so as to correct the tilt in the latter in favour of the carriers. The Hamburg Rules are acclaimed to be a great improvement on the Hague Rules and far more beneficial from the point of view of the cargo owners. India has also not adopted the International Convention relating to the Arrest of Seagoing Ships, Brussels, 1952. Nor has India adopted the Brussels Convention 1952 on civil and penal jurisdiction in matters of collision; nor the Brussels Conventions of 1926 and 1967 relating to maritime liens and mortgages. India seems to be lagging behind many other countries in ratifying and adopting the beneficial provisions of various conventions intended to facilitate international trade. Although these conventions have not been adopted by legislation, the principles incorporated in the conventions are themselves derived from common law of nations embodying the felt necessities of international trade and are as such part of common law of India and applicable for the enforcement of maritime claims against foreign ships.

Displacement and rehabilitation of tribals and other persons - applicability of ILO Convention 107 to which India is a signatory - Resolution of the United Nations Water Conference 1977

\section{NARMADA BACHAO ANDOLAN v. UNION OF INDIA AND OTHERS}

\section{Supreme Court of India, 18 October 2000 AIR 2000 Supreme Court 3751}

\footnotetext{
8 The Court, inter alia, held that "Both the English Admiralty Court, which is, admittedly, a Court of competent jurisdiction, as well as the Andhra Pradesh High Court being a corresponding Court of Competent admiralty jurisdiction, could not only entertain such a suit in the first instance but could equally be competent to execute such a decree of Admiralty Court.

${ }^{9}$ M.V. Elisabeth v. Harwan Investment and Trading Pvt. Ltd., AIR 1993 Supreme Court 1014
} 
Facts

The case related to construction of various hydropower and irrigation projects and the consequent displacement of a large population on the river Narmada, one of the largest rivers flowing in Central India. The issue also involved, inter alia, the decision on the height of one of the dams known as the Saradar Sarovar Project. These projects on the river had been taken up for basin-wise development of the river with flood control, irrigation, power and extension of the navigation. This resulted in the large-scale displacement of people, particularly the tribal population located in different village clusters. The Petitioner, a non-governmental organization working for the rehabilitation of the tribal villages in the Narmada Valley, had put forward three strands of arguments relating to (a) the environment; (b) relief and rehabilitation; and (c) the necessity for reviewing the whole project. ${ }^{10}$

State Practice and Implementation:

The Court, while on the issue of relief and rehabilitation of the tribals, noted:

While accepting the legal proposition that International Treaties and Covenant can be read into domestic laws of the country the submission of the respondents was that Article 12 of the ILO Convention No. 107 stipulates that "the populations concerned shall not be removed without their free consent from their habitual territories except in accordance with national laws and regulations relating to national security, or in the interest of national economic development or of the health of the said populations". ${ }^{11}$ The said Article clearly suggested that when the removal of the tribal population is necessary as exceptional measure, they shall be provided with land of quality at least equal to that of the land previously occupied by them and they shall be fully compensated for any resulting loss or injury. ${ }^{12}$

10 The Court did not agree to the review of the whole project.

11 With regard to the aspects of relief and rehabilitation (R\&R), the Court elaborated further

"...Displacement of people living on the proposed project sites and the areas to be submerged is an important issue. Most of the hydrology projects are located in remote and inaccessible areas, where local population is, like in the present case, either illiterate or having marginal means of employment and the per capita income of the families is low. It is a fact that people are displaced by projects from their ancestral homes. Displacement of these people would undoubtedly disconnect them from their past, culture, custom and traditions, but then it becomes necessary to harvest a river for larger good. A natural river is not only meant for the people close by but it should be for the benefit of those who can make use of it, being away from it or nearby. Realising the fact that displacement of these people would disconnect them from their past, culture, custom and traditions, the moment any village is earmarked for take over for dam or any other development activity, the project implementing authorities have to implement R\&R programmes".

12 The Court also refers to various internal mechanisms such as Rehabilitation Committees, monitoring of rehabilitation programmes by concerned Government Agencies, and various forms of Grievance Redressal Mechanisms for the assistance of the project affected population. 
Referring to 'water availability' as a basic need and a human right, the Court observed:

Water is the basic need for the survival of human beings and is part of right of life and human rights as enshrined in Article 21 of the Constitution of India ${ }^{13}$ and can be served only by providing a source of water where there is none. The Resolution of the UNO in 1977 to which India is a signatory, during the United Nations Water Conference resolved unanimously inter alia as under:

"All people, whatever their stage of development and their social and economic conditions, have the right to have access to drinking water in quantum and of a quality equal to their basic needs"

Extradition - Extradited person can be tried only for offences mentioned in the extradition decree and for no other offences - Doctrine of Speciality under International Law - Evolution of extradition conventions and practices

\section{DAYA SINGH LAHORIA v. UNION OF INDIA AND OTHERS}

\section{Supreme Court of India, 17 April 2001 AIR 2001 Supreme Court 1716}

Facts

The Petitioner contended that the criminal courts in the country had no jurisdiction to try in respect of offences that did not form a part of the extradition judgment by virtue of which the petitioner was brought to this country, and he could be tried only for the offences mentioned in the extradition decree. Therefore, he could not be tried for offences other than the offences mentioned in the extradition order issued pursuant to an extradition treaty between India and USA.

The Petitioner also referred to Section 21 of the Extradition Act of India, $1962^{14}$ (as amended in 1993) which provided:

Whenever any person accused or convicted of an offence, which, if committed in India would be an extradition offence, is surrendered or returned by a foreign State, such person shall not, until he has been restored or has had an opportunity of returning to that State, be tried in India for an offence other than (a) the extradition offence in relation to which he was surrendered or returned; or (b) any lesser offence disclosed by the facts proved for the purposes of securing his surrender or return other than an offence in relation to which an order for his surrender or return could not be

\footnotetext{
13 Article 21 provides "No person shall be deprived of his life or personal liberty except according to procedure established by law".

14 The original Extradition Act, 1962 was amended in 1993 by Act 66 of 1993.
} 
lawfully made; or (c) the offence in respect of which the foreign State has given its consent.

Reference was also made to Article 7 of the Extradition Treaty between India and $\mathrm{USA}^{15}$ according to which:

A person surrendered can in no case be kept in custody or be brought to trial in the territories of the High Contracting Party to whom the surrender has been made for any other crime or offence, or on account of any other matters, than those for which the extradition shall have taken place, until he has been restored, or has had an opportunity of returning, to the territories of the High Contracting Party by whom he has been surrendered. The stipulation does not apply to crimes or offences committed after the extradition.

State Practice and Implementation:

While noting that Section 21 of the Extradition Act was in consonance with Article 7 of the Extradition Treaty, the Court observed:

...Extradition is a great step towards international cooperation in the suppression of crime. It is for this reason the Congress of Comparative Law held at [The] Hague in 1932, resolved that States should treat extradition as an obligation "resulting from the international solidarity in the fight against crime". In Oppenheim, International Law, the expression is defined as "Extradition is a delivery of an accused or a convicted individual to the State on whose territory he is alleged to have committed or to have been convicted of a crime, by the State on whose territory the alleged criminal happens for the time to be". There is no rule of international law which imposes any duty on a State to surrender a fugitive in the absence of an extradition treaty. The law of extradition, therefore, is a dual law. It is ostensibly a municipal law; yet it is a part of international law also, inasmuch as it governs the relations between two sovereign States over the question whether or not a given person should be handed over by one sovereign State to another sovereign State. This question is decided by national Courts on the basis of international commitments as well as on the rules of international law relating to the subject. A number of attempts have been made to conclude a convention governing extradition requests among nations. The Pan American Conference of 1902 produced a treaty of extradition signed by twelve States, but it was not ratified. In 1933 the Seventh Pan American Conference concluded an Extradition Convention, which was ratified by number of States, including

15 This was a treaty between the USA and the UK made applicable to India pursuant to section 2 (d) of the Extradition Act of India, 1962 according to which 'extradition treaty' means "a treaty (agreement or arrangement) made by India with a foreign State relating to the extradition of fugitive criminals and includes any treaty relating to the extradition of fugitive criminals made before the $15^{\text {th }}$ day of August 1947 which extends to and is binding on India". The present Extradition Treaty between India and USA came into force on 21 July 1999. 
United States of America, but the League Codification Committee had doubted the feasibility of the general convention on extradition. In 1935, the Harvard Law School brought out a draft convention on the subject. The International Law Association has also considered legal problems relating to extradition in the conference held at Warsaw. In 1928 the draft convention on extradition was approved but nothing has materialized in concluding a universal convention on extradition, notwithstanding the fact that most States earnestly believe in the efficacy and usefulness of extradition proceedings which each State has to resort to at one time or the other. The AsianAfrican Legal Consultative Body also prepared a draft convention on extradition at its meeting in Colombo in 1960. In September 1965, the Commonwealth Conference of Law Ministers and Chief Justices expressed the desire for a Commonwealth Convention on Extradition. In March 1966, the Commonwealth Law Ministers reached an agreement in London for the speedy extradition of fugitive between Commonwealth Counties. But, in the absence of any extradition convention, nations have resorted to bilateral extradition treaties by which they have agreed between themselves to surrender the accused or convict to the requesting State in case such person comes under the purview of the given treaty. Bilateral treaties at the international level are supplemented by national laws or legislation at the municipal level. Extradition treaties between nations, draft conventions and national laws and practices have revealed that some customary rules of international law have developed in the process. The doctrine of Speciality is yet another established rule of international law relating to extradition. Thus, when a person is extradited for a particular crime, he can be tried for only that crime. If the requesting State deems it desirable to try the extradited fugitive for some other crime committed before his extradition, the fugitive has to be brought to the status quo ante, in the sense that he has to be returned first to the State which granted the extradition and a fresh extradition has to be requested for the latter crime. The Indian Extradition Act makes a specific provision to that effect.

...The doctrine of speciality is in fact a corollary to the principles of double criminality, and the aforesaid doctrine is premised on the assumption that whenever a State uses its formal process to surrender a person to another State for a specific charge, the requesting State shall carry out its intended purpose prosecuting or punishing the offender for the offence charged in its request for extradition and none other.

Interpretation of Article II (2) of the New York Convention on Recognition and Enforcement of Foreign Arbitral Awards, 1958 - Scope of application of 'agreement in writing' in the context of an arbitration agreement - the contours of 'public policy' in the context of Indian law

SMITA CONDUCTORS v. EURO ALLOYS LTD

Supreme Court of India, 31 August 2001

AIR 2001 Supreme Court 3730 
Facts

This case raised issues relating to the interpretation of Article II (2) of the New York Convention on the Recognition and Enforcement of Foreign Arbitral Awards, 1958 (hereinafter 'The New York Convention'). Article II of the Convention referred to "agreement in writing" and as to what constituted "agreement in writing".

In this case, a contract to supply certain items was proposed by the respondent to the appellant with an accompanying letter to complete the formalities of signing and returning a copy for the sake of good order. The Appellant neither signed nor returned the contract format. Reminders were also sent to which there was no response from the Appellant. Even the second contract was not signed. Shipments were, however, made by the Appellant on the basis of certain irrevocable letters of credit. In March 1991, the Reserve Bank of India (RBI) placed certain restrictions on the import of goods. In another notification, RBI modified the margins for opening letters of credit. The Appellant sent a telex to the Respondent to the effect that severe restrictions had been imposed by the RBI due to an unprecedented foreign exchange crisis. Accordingly, the Appellant further noted, RBI had not cleared his application for a letter of credit. Accordingly, the Appellant invoked the force majeure clause cancelling shipment for both the contracts.

The Respondent initiated arbitration proceedings with respect to both the contracts before the London Metal Exchange. While the arbitration proceedings continued before the London Metal Exchange, the Appellant had pursued litigation in India seeking revocation of the arbitration proceedings. Indian courts refused to intervene. Meanwhile, the arbitration proceedings before the London Metal Exchange were concluded and an award was issued against the Appellant. The Respondent filed a suit before the Mumbai High Court seeking enforcement of the said award. The Appellant filed this case seeking a declaration that there was no valid agreement between the parties as there was no 'agreement in writing' (in terms of Article II (2) of the New York Convention) and that the arbitration before the London Metal Exchange was void.

State Practice and Implementation:

The Appellant's contention was that a foreign award could be enforced if it was in pursuance of an agreement in writing for arbitration vide the New York Convention. ${ }^{16}$ The arbitration award in the present case was not pursuant to an agreement in terms of Article II of the New York Convention. The expression 'agreement in

16 India became a party to the New York Convention for the Enforcement of Foreign Arbitral Awards, 1958 on 13 July 1960. The New York Convention had been given effect by a separate legislation in India, namely the Foreign Arbitral Awards (Recognition and Enforcement) Act, 1961. This Act has been repealed in the new Arbitration and Conciliation Act, 1996 which is based on the United Nations Commission on International Trade Law (UNCITRAL) Model Law on International Commercial Arbitration, 1985. The New York Convention now forms part of the new 1996 Act and appears in the first schedule of the Act. 
writing', according to Article II (2) of the New York Convention, would include an arbitral clause in a contract or an arbitration clause signed by the parties or contained in the exchange of letters or telegrams. ${ }^{17}$

The Respondent, on the other hand, argued that the correspondence between the parties and the conduct of the Appellant clearly established that there existed an arbitration clause between the parties and, therefore, there was full compliance with Article II of the New York Convention. The Court noted the submission of the Respondent in the following way:

...the definition of what constitutes a written arbitration agreement given in Article II (2) can be deemed to be an internationally uniform rule which prevails over any provisions of Municipal law regarding the form of the arbitration agreement in those cases where the Convention is applicable. The Courts in the contracting States have generally affirmed the uniform rule character of Article II (2). ${ }^{18}$

The Appellant contended that the award was contrary to public policy of India and RBI had issued certain circulars imposing restrictions on imports and, therefore, attracted the force majeure clause. The Court noted:

The question of what is the 'public policy' has been considered by this Court in Renusagar's case by interpreting the words in section 7 (1) (b) (ii) of the Act to mean 'public policy of India and not of the country whose law governs the contract or of the country of place of arbitration'. In doing so, this Court took note of the fact that under Arbitration (Protocol and Convention) Act, 1937 the expression 'public policy of India' had been used, whereas the expression 'public policy' is used in the Act; that after the decision of this Court in V.O. Tractoroexport, Moscow v. Tarapore \& Co. (1970) 3 SCR 53, S.3 was substituted to bring it in accord with the provisions of New York Convention on Arbitration, 1958 which seeks to remedy the defects in the Geneva Convention of 1927 that hampered the speedy settlement of disputes through arbitration; that to achieve this objective by dispensing with the requirement

17 The Appellant in support of his argument cited several decisions of different Courts reported in the Year Book of International Commercial Arbitration, with particular reference to the interpretation of Article II of the New York Convention on 'agreement in writing'. Notable among them were: a case decided by the US District Court between Sen Mar Inc (US) v. Tiger Petroleum Corporation N.V. (1993) in which the Respondent's responsive telexes were held to be devoid of arbitration language; Italian Court of Appeal in Finagrain Compagnie Commerciale Agricole et Financiere S.A. v. Patano Snc (Italy) (1996) in which case there were three contracts and the Court upheld the validity of two contracts for the purpose of enforcement as per Article II of the New York Convention and found the third contract short of that requirement; Decision of the Swiss Court in Gaetano Butera (Italy) v. Pietro e Romano Pagnan (Italy) (1979) wherein arbitral clause was held to be void as it was signed by one of the parties.

18 Reference has also been made to an earlier decision of the Indian Supreme Court in the case of Renusagar Power Co. Ltd. v. General Electric Company (1994) AIR 1994 Supreme Court 860. In this case the Supreme Court of India held that the New York Convention controlled the proceedings in arbitration. 
of the leave to enforce the award by the Courts where the award is made and thereby avoid the problem of double exequatur; that the scope of enquiry is restricted before the Court enforcing the award by eliminating the requirement that the award should not be contrary to the principles of the law of the country in which it is sought to be relied upon; that enlarging the field of enquiry to include public policy of the country whose law governs the contract or of the country of place of arbitration would run contrary to the expressed intent of the legislation. Therefore, it was held that the words 'public policy' [are] intended to broaden the scope of enquiry so as to cover the policy of other countries, that is, the country whose law governs the contract or the country of the place of arbitration. In the absence of a definition of the expression 'public policy', it is construed to mean the doctrine of public policy as applied by the Courts in which the foreign award is sought to be enforced and this Court referred to a large catena of cases in this regard. Therefore, we will proceed on the basis that the expression 'public policy' means public policy of India, and the recognition and enforcement of foreign award cannot be questioned on the ground that it is contrary to the foreign country pubic policy and this expression has been used in a narrow sense must necessarily be construed as applied in private international law which means that a foreign award cannot be recognized or enforced if it is contrary to (1) fundamental policy of Indian law; or (2) the interests of India; or (3) justice or morality.

The Court rejected the contentions of the Appellant and decided not to interfere or modify the award made by the arbitrators.

Appointment of Arbitrators by the Court - Article 11 of the UNCITRAL Model Law on International Commercial Arbitration vis-à-vis section 11 of the Indian Arbitration and Conciliation Act, 1996 - Issues of compatibility

M/S KONKAN RAILWAY CORPORATION LTD v. M/S RANI CONSTRUCTION PVT LTD.

\section{Supreme Court of India, 30 January 2002 AIR 2002 Supreme Court 778}

Facts

The issue before the Constitution Bench of the Supreme Court was whether an order under Section 11 of the Arbitration and Conciliation Act, $1996^{19}$ to appoint (or refuse to appoint) an arbitrator by the Chief Justice or any person designated by

19 Section 11 deals with the appointment of arbitrators. If the parties fail to agree on the appointment of arbitrators, the Chief Justice or any other person designated by him could be requested to make the appointment. This provision is based on the UNCITRAL Model Law on International Commercial Arbitration. 
him to take the necessary measure in this regard was an administrative order or a judicial order, and whether it was amenable to the jurisdiction of the Supreme Court under Article 136 of the Constitution. ${ }^{20}$

State Practice and Implementation:

The Section 11 of the Indian Arbitration and Conciliation Act, 1996 with regard to the appointment of arbitrators was based on Article 11 of the UNCITRAL Model Law. The Court noted:

...The Statement of Objects and Reasons of the Act states, "Though the said UNCITRAL Model Law and Rule are intended to deal with international commercial arbitration and conciliation, they could, with appropriate modifications, serve as a model for legislation on domestic arbitration and conciliation. The present Bill seeks to consolidate and amend the law relating to domestic arbitration, international commercial arbitration, enforcement of foreign arbitral awards and to define the law relating to conciliation, taking into account the said UNCITRAL Model Law and Rules". That the Model Law was only taken into account in the drafting of the said Act is, therefore, patent. The Act and the Model Law are not identically drafted. Under Section 11 the appointment of an arbitrator, in the event of a party to the arbitration agreement failing to carry out his obligation to appoint an arbitrator, is to be made by "the Chief Justice or any person or institution designated by him", under clause 11 of the Model Law it is to be made by a Court. Section 34 of the Act is altogether different from clause 34 of the Model Law. The Model Law and judgments and literature thereon are, therefore, not a guide to the interpretation of the Act and, especially of Section 11 thereof.

The Court, in conclusion, held that "...the order of the Chief Justice or his designate under section 11 nominating an arbitrator is not an adjudicatory order and the Chief Justice or his designate is not a tribunal".

\footnotetext{
20 Article 136 of the Indian Constitution empowers the Supreme Court to grant special leave to appeal from any judgment, decree, sentence or order in any cause or matter passed or made by any Court or tribunal in the territory of India.
} 


\section{INDONESIA $^{21}$}

\section{JUDICIAL DECISIONS}

Crimes against humanity; universal jurisdiction

Injunction Decision No. 01/Pid HAM Ad Hoc/2002/PN JAKPUS dated 4 April 2002

\section{PROSECUTOR OFFICE OF THE REPUBLIC OF INDONESIA v. ABILIO JOSE OSARIO SOARES}

In this case Abilio Jose Osario Soares was accused of crimes against humanity under Law No. 26 of 2000. One of the arguments put forward by Soares in his defence was that the ad hoc Human Rights Court of the Central Jakarta Court did not have the competence to examine his case since the alleged crime was not considered as an act of crime when it happened and, thus, this was against the principle of nullum crimen sine lege.

The Court rejected Soares's argument, stating that crimes against humanity constitute an international crime. As an international crime the principle of universal jurisdiction applies. As a consequence, the principle Nullum Crimen Sine Lege can be put aside.

\section{Injunction Decision No. 02/AD HOC/2002 dated 28 March 2002}

PROSECUTOR OFFICE OF THE REPUBLIC OF INDONESIA v. TIMBUL SILAEN

In this case Timbul Silaen was accused of crimes against humanity under Law No. 26 of 2000. One of the arguments put forward by Silaen on the issue of jurisdiction was that the ad hoc Human Rights Court of the Central Jakarta Court did not have the jurisdiction to examine his case since the alleged crime occurred in East Timor, which was not in Jakarta.

The Court rejected Silaen's argument since crimes against humanity constitute an international crime. As an international crime the principle of universal jurisdiction applies. Under this principle any court may exercise jurisdiction to examine any alleged international crime.

${ }^{21}$ Contributed by Hikmahanto Juwana, Professor of International Law, University of Indonesia. 


\section{NATIONAL LAWS ON INTERNATIONAL LAW MATTERS}

\section{Anti-Terrorism Law}

\section{Republic of Indonesia, Government Regulation in Lieu of Law No. 1 of 2002 - "Combating Criminal Acts of Terrorism",22}

On October 18, 2002 the President issued Government Regulation in Lieu of Law (hereinafter referred to as GRL) No. 1 of 2002 concerning the Eradication of Criminal Acts of Terrorism. This was a response to the Bali Bombing on 12 October 2002 which killed almost 200 holidaymakers, mostly foreigners.

The GRL provides several reasons for its promulgation. First, terrorism had claimed human lives intolerably and raised widespread fear among the community. It had also caused loss of freedom and damage to property. Therefore, measures need to be taken to eliminate the act of terrorism. In addition, the government acknowledged that terrorism has maintained extensive networks, such that it poses a threat to national and international peace and security. In order to meet national and international commitments to combat terrorism it was important to pass a national legislation with reference to international conventions relating to terrorism. Lastly, the GRL was a matter of urgency since there was as yet no legislation in Indonesia dealing comprehensively or adequately with combating criminal acts of terrorism.

The GRL applies to any person who commits or intends to commit a criminal act of terrorism in the territory of the Republic of Indonesia and/or another nation that has jurisdiction and expresses an intention to prosecute that person.

The GRL also applies to criminal acts of terrorism which are committed: (a) against the citizens of the Republic of Indonesia outside the territory of the Republic of Indonesia; (b) against the state facilities of the Republic of Indonesia overseas, including the premises of the diplomatic officials and consuls of the Republic of Indonesia; (c) with violence or threats of violence to force the Government of Indonesia to take or not to take an action; (d) to force any international organization in Indonesia to take or not take an action; (e) on board a vessel sailing under the flag of the Republic of Indonesia or an aircraft registered under the laws of the Republic of Indonesia at the time when the crime is committed; and (f) by any stateless person who resides in the territory of the Republic of Indonesia.

Under the GRL, the act of terrorism is divided into those who are committing the act of terrorism and those who have the intention to commit an act of terrorism.

There are various acts of terrorism defined under GRL. The most important is any person who intentionally uses violence or the threat of violence to create a widespread atmosphere of terror or fear in public or to create mass casualties, by forcibly taking the freedom, life or property of others or causes damage or destruction to vital strategic installations or the environment or public facilities or international facilities. Those who commit these kinds of acts of terrorism can be sentenced in

${ }^{22}$ The English translation is available at: http://www.law.unimelb.edu.au/alc/indonesia/gr_1.html (last visited 23 January, 2003) 
the form of death penalty, life imprisonment, or a minimum sentence of 4 years and a maximum of 20 years. Those who have the intention to commit act of terrorism can be sentenced to a maximum of life imprisonment.

Other acts of terrorism are: (a) destroying, rendering inoperational or damaging facilities associated with air traffic and aviation security or causes the operation of such facilities to fail; (b) causing the destruction, inoperability or damage to facilities associated with aviation security or causes the operation of such facilities to fail; (c) intentionally and illegally destroying, damaging, removing or moving signs or equipment associated with aviation security, or causing the operation of said signs or equipment to fail, or erecting incorrect signs or equipment; (d) due to his or her negligence aviation security signs or equipment are destroyed, damaged, removed or moved or incorrect aviation security signs or equipment are erected; (e) intentionally and illegally destroying or rendering inoperational any aircraft partly or wholly belonging to another party; (f) intentionally and illegally causing the crash, destruction, rendering inoperational or damage to an aircraft; $(\mathrm{g})$ through his or her negligence causes an aircraft to crash, be destroyed, in-operational or damaged; (h) for the purposes of self-enrichment or the enrichment of another person, illegally obtains insurance and then causes arson or explosion, crash, destruction, damage or renders inoperational an aircraft insured against danger or its contents or profit are insured against danger; (i) while aboard an aircraft uses illegal means to takeover, defend a takeover or otherwise control an aircraft in flight; (j) while aboard an aircraft uses violence or threats of violence or threats in any other form, takes over or defends a takeover or takes on control of an aircraft in flight; $(\mathrm{k})$ jointly engages in a criminal plot, with prior planning, to cause serious injuries to any person, resulting in damage to an aircraft that could endanger the flight, committed with the intention of takeover of the freedom or of infringing upon the freedom of any person; (l) intentionally and illegally committing violence against a person in an aircraft in flight, where the act could endanger the safety of the aircraft; $(\mathrm{m})$ intentionally and illegally damaging an aircraft on duty or causing damage to an aircraft that renders the aircraft incapable of flight or endangers the safety of the flight; (n) intentionally and illegally placing or causing to be placed aboard an aircraft on duty, by any means whatsoever, an object or substance capable of destroying an aircraft, rendering it incapable of flight or causing to the aircraft damage capable of endangering the flight; (o) jointly committing with two or more other persons as part of previously planned plot resulting in serious injuries to a person any act in point $(\mathrm{l}),(\mathrm{m})$ and $(\mathrm{n})$; (p) providing information known to be false and thereby endangering the safety of an aircraft in flight; (q) while aboard an aircraft committing an act capable of endangering the safety of the aircraft in flight; and (r) while aboard an aircraft committing an act capable of disturbing law and order on the aircraft in flight.

Those who are found guilty of the above acts of terrorism can be sentenced in the form of the death penalty, life imprisonment, or a minimum prison sentence of four years and a maximum of 20 years.

It should be noted that the GRL provides that the various acts of terrorism will not be applicable to politically criminal acts nor to criminal acts relating to political 
crimes nor to criminal acts with political motives nor to criminal acts with the political objective of obstructing an extradition process.

The GRL also provides that any person who unlawfully imports into Indonesia, makes, receives, attempts to acquire, delivers or attempts to deliver, controls, carries, has the stock of his own or has in his possession, stores, transports, hides, uses, or carries in or out of Indonesia any firearm, ammunition, explosive substance or other dangerous material with the intention to commit any act of terrorism is a criminal act. The sentence for those found guilty can be in the form of death penalty, life imprisonment, or a minimum prison sentence of three years and a maximum of 20 years.

In addition, a person will be criminally charged under the GRL if such person intentionally uses chemical or biological weapons, radiology, micro-organisms, radioactivity or its components to create an atmosphere of terror or fear in the general population, causes large number of casualties, causes danger to health, to cause chaos to life, security, and other people's rights, or to cause damage and destruction to vital strategic installations or the environment or public facilities, or international facilities. The sentence for those found guilty can be in the form of death penalty, life imprisonment, or a minimum prison sentence of four years and a maximum of 20 years.

Furthermore, those who intentionally provide or collects funds with the objective that they be used or there is a reasonable likelihood to be used partly or wholly for criminal acts of terrorism will bear criminal responsibility under the GRL. Those who are found guilty can be sentenced of a minimum of four years of imprisonment or a maximum of 15 years.

Moreover, a person can be qualified as committing an act of terrorism if such person intentionally provides or collects assets with the objective to be used or there is a reasonable likelihood to be used partly or wholly for: (a) committing any unlawful act of receiving, possessing, using, delivering, modifying or discarding nuclear materials, chemical weapons, biological weapons, radiology, micro-organism, radioactivity or its components that causes death or serious injuries or causes damage to assets; (b) stealing or seizing nuclear materials, chemical weapons, biological weapons, radiology, micro-organism, radioactivity or its components; (c) embezzling or acquiring illegally nuclear materials, chemical weapons, biological weapons, radiology, micro-organism, radioactivity or its components; (d) requesting nuclear materials, chemical weapons, biological weapons, radiology, micro-organism, radioactivity or its components; (e) threatening to: (1) use such nuclear materials, chemical or biological weapons, radiology, micro-organisms, radioactivity or its components to cause death or injuries or damage to properties; or (2) commit criminal acts as stipulated in (b) with the intention to force another person, an international organization, or another country to take or not to take an action; (f) attempting to commit any criminal act as stipulated in (a), (b) or (c); and (g) participating in committing any criminal act as stipulated in (a) to (f).

The sentence for those found guilty is imprisonment within a minimum prison sentence of three years and a maximum of 15 years. 
The GRL also provides that any person who intentionally provides assistance to any perpetrator of criminal acts of terrorism by: (a) providing or lending money or goods or other assets to any perpetrator of criminal acts of terrorism; (b) harbouring any perpetrator of any criminal act of terrorism; or (c) hiding any information on any criminal act of terrorism will be criminally charged. The sentence for those found guilty is imprisonment with a minimum sentence of three years and a maximum of 15 years.

Furthermore, any person who plans and/or incites other person to commit any criminal act of terrorism can be sentenced either to the death penalty or to life imprisonment.

Moreover, any person who conducts any plot, attempt, or assistance to commit any criminal act of terrorism will be sentenced the same as those who are committing any such act of terrorism.

One interesting point to note is the GRL can also be applied to those who provide any assistance, facilities, means or information for the committing of any criminal act of terrorism which are outside the territory of the Republic of Indonesia. The sentence is the same as the sentence for those committing the act of terrorism.

Another interesting point is the GRL provides for criminal responsibility of corporations involved in any act of terrorism. It is stipulated that in the event an act of terrorism is committed by or on behalf of a corporation, the prosecution and sentencing shall be carried out against such a corporation or its management. An act of terrorism shall be deemed to have been committed by a corporation if the criminal act is committed by persons who, based on their work relationship or other relationships, act in the environment of such corporation either individually or jointly. In the event the prosecution is brought against a corporation, then its management shall represent the corporation.

The GRL also stipulates other criminal offences related to acts of terrorism. To take an example, any person who uses violence or the threat of violence or who intimidates detectives, investigators, public prosecutors, solicitors and/or judges who are handling any criminal act of terrorism, so as to hamper the judicial process, will be criminally charged. The sentence is a minimum imprisonment of three years to a maximum of 15 years. Another example is a person who provides false testimonies, submits false material evidence, and unlawfully influences witnesses during a court session or attacks the witnesses, including the court officials in the trial of a criminal act of terrorism, can also be criminally charged. The sentence is imprisonment of a minimum of three years and a maximum of 15 years.

The GRL introduces a novel procedure from ordinary criminal procedure, that is, an investigator may use any intelligence report as preliminary evidence. However, the GRL provides that the adequacy of the preliminary evidence obtained must be determined through an inquiry process by the Head or its Deputy of the District Court. The inquiry process is conducted in closed session within a maximum period of 3 (three) working days.

The GRL provides various extraordinary powers to investigators, public prosecutors and judges. 
Investigators may detain any person strongly suspected of committing a criminal act of terrorism based on adequate preliminary evidences for a maximum period of seven times twenty-four hours.

Investigators, public prosecutors or judges are authorized to order banks and other financial institutions to freeze the assets of any individual whose assets are known or reasonably suspected to be the proceeds of any criminal act connected to terrorism.

In addition the GRL provides that for the purpose of investigation, the investigators, public prosecutors or judges are authorized to request information from banks and other financial institutions regarding the assets of any person who is known or strongly suspected of having committed a criminal act of terrorism.

Furthermore, investigators are authorized (a) to open, examine and confiscate mail and packages by post or other means of delivery; and (b) to intercept any conversation by telephone or other means of communication suspected of being used to prepare, plan and commit a criminal act of terrorism. However, investigators may intercept only when based on an order of the Head of the District Court for a maximum period of one year.

The GRL stipulates protection for those involved in the criminal process of terrorism case. Witnesses, investigators and judges and their families are entitled to protection by the State from any possible threat endangering themselves, their lives and/or properties including before, during or after the investigation process.

The Court may examine and render a decision even if the defendant is not present (in absentia). This occurs if the defendant has been officially and appropriately summoned but without valid reason does not appear before the court.

The GRL also imposes an obligation on the state to pay compensation and restitution to victims of terrorist acts. It provides that any victim and the family of victims of a wrong act of terrorism shall be eligible for compensation and/or restitution. In addition, any individual shall be entitled to rehabilitation if he/she is discharged of all legal charges by the court with permanent legal power.

The GRL obligates Indonesia to conduct international cooperation with other nations in the areas of intelligence, the police department and other technical cooperation connected with anti-terrorism measures in accordance with the applicable legislative provisions.

The GRL stipulates that provisions of the GRL may be applied retroactively to acts of terrorism that occurred prior to the promulgation of this GRL, provided that such application is determined by legislation in the form of an Act of a GRL.

\section{Republic of Indonesia, Government Regulation in Lieu of Law No. 2 of 2002 - "The Enactment of Government Regulation in Lieu of Legislation Number 1, 2002 on Combating Criminal Acts of Terrorism, in relation to the Bombing in Bali on 12 October 2002,"23}

\footnotetext{
${ }^{23}$ The English translation is available at: http://www.law.unimelb.edu.au/alc/indonesia/gr_2.html (last visited 23 January 2003).
} 
On the same day the Government issued GRL 1 of 2002, another GRL was issued known as GRL No. 2 of 2002. The GRL is issued by taking into account the retroactive provision provided under GRL 1 of 2002. GRL 2 of 2002 is issued to give legal basis for the perpetrator of the Bali bombing to be prosecuted based on GRL 1 of 2002.

GRL 2 of 2002 contains only two articles. Article 1 provides that the provisions of GRL 1 of 2002 are deemed to take effect in relation to the bombing incident which occurred in Bali on 12 October 2002. Article 2 provides that the GRL take effect on the date it was enacted.

The reason for applying GRL 1 of 2002 retroactively is found in the elucidation of GRL 2 of 2002. It is stated that terrorism is considered as a crime against humanity and civilization.

\section{AIR LAW}

Republic of Indonesia, Government Regulation No. 3 of 2001 - “Aviation Security and Safety"

On February 5, 2001 Indonesia issued Government Regulation (hereinafter abbreviated as "GR") No. 3 of 2001 concerning Aviation Security and Safety as implementing regulation of provisions under Law 15 of 1992 concerning Aviation.

The GR provides detailed rules on aviation security and safety. The Minister in charge of civil aviation has the responsibility to assure aviation security and safety. The GR gives the Minister the power to regulate, control and supervise a range of activities from designing, manufacturing, operating and maintenance of aircraft to navigation service and airport operation, as well as determining the requirement for aviation personnel.

To take an example, the Minister has the responsibility to determine the requirements for aircraft reliability and, thus, provides guidelines in the design, manufacturing, operation and maintenance of aircraft.

Furthermore, the GR stipulates in detail provisions on the use and operation of an aircraft. It provides that the commercial operation of the aircraft for air transport purposes can be carried out only by aircraft operators holding a certificate issued by the Minister.

The GR also regulates Indonesia's air space and traffic, and contains provisions on search and rescue in the event of an aircraft accident, as well as protection regarding pollution of the air.

\section{SPACE LAW}

Republic of Indonesia, Law No. 16 of 2002 - "The Ratification of Treaty on Principles Governing the Activities of States in the Exploration and Use of Outer Space, Including the Moon and Other Celestial Bodies, 1967" 
On April 17, 2002, Indonesia finally ratified the Treaty on Principles Governing the Activities of States in the Exploration and Use of Outer Space, Including the Moon and Other Celestial Bodies (Space Treaty 1967). The main reason for Indonesia's not acceding earlier to the Space Treaty of 1967 was due to Indonesia's claim over the Geo-stationery Orbit (hereinafter abbreviated as "GSO").

For many years Indonesia along with other equatorial countries has been struggling for their claim of the GSO. In December 3, 1977 in Bogotá, the equatorial countries issued a declaration known as the Bogotá Declaration to claim the GSO above their territories.

The ratification of the Space Treaty of 1967 has put an end to the long struggle by Indonesia over the GSO.

\section{LAW OF THE SEA}

Republic of Indonesia, Government Regulation No. 37 of 2002 - "The Rights and Obligations of Foreign Ships and Aircraft when Exercising the Right of Archipelagic Sea Lanes Passage through Established Archipelagic Sea Lanes",24

On June 28, 2002 the Government issued GR No. 37 of 2002. The GR is intended to serve as implementing regulation of Law 6 of 1996 concerning Indonesian Waters. Under Law 6 of 1996 it is provided that the government has the authority to determine the sea lanes, including flight routes above the sea lanes. In addition, it has the responsibility to regulate the rights and obligations of foreign ships and aircraft when exercising the right of sea lanes passage in the archipelagic waters.

Under GR 37 of 2002, foreign ships and aircraft may exercise the right of archipelagic sea lanes passage in order to sail or fly from one part of the high seas or an exclusive economic zone to another part of the high seas or an exclusive economic zone through or over the Indonesian territorial sea and its archipelagic waters.

The archipelagic sea lane that may be used for exercising the right of archipelagic sea lanes passage for sailing from the South China Sea to the Indian Ocean or vice versa through the Natuna Sea, the Karimata Strait, the Java Sea and the Sunda Strait is Archipelagic Sea Lane I.

The archipelagic sea lane that may be used for exercising the right of archipelagic sea lanes passage for sailing from the Sulawesi Sea to the Indian Ocean or vice versa through the Makassar Strait, the Flores Sea and the Lombok Strait is Archipelagic Sea Lane II.

The archipelagic sea lane that may be used for exercising the right of archipelagic sea lanes passage for sailing from the Pacific Ocean to the Indian Ocean or vice versa through the Maluku Sea, the Seram Sea, the Banda Sea, the Ombai Strait and the Sawu Sea is Archipelagic Sea Lane IIIA.

\footnotetext{
${ }^{24}$ The English translation is available at http://www.law.unimelb.edu.au/alc/assets/ships_aircraft.doc (last visited 23 January 2003).
} 
The Archipelagic Sea Lane IIIA, includes (a) Archipelagic Sea Lane Branch IIIB, which joins Archipelagic Sea Lane IIIA at point IIIA-8, for sailing from the Pacific Ocean to the Indian Ocean or vice versa through the Maluku Sea, the Seram Sea, the Banda Sea and the Leti Strait, of which the axis is the line that joins connecting points IIIA-8, IIIB-1 and IIIB-2; Archipelagic Sea Lane Branch IIIC, which joins Archipelagic Sea Lane Branch IIIB at point IIIB-1, for sailing from the Pacific Ocean to the Arafura Sea or vice versa through the Maluku Sea, the Seram Sea and the Banda Sea, of which the axis is the line that joins connecting points IIIB-1, IIIC-1 and IIIC-2; Archipelagic Sea Lane Branch IIID, which joins Archipelagic Sea Lane IIIA at point IIIA-11, for sailing from the Pacific Ocean to the Indian Ocean or vice versa through the Maluku Sea, the Seram Sea, the Banda Sea, the Ombai Strait and the Sawu Sea, of which the axis is the line that joins connecting points IIIA-11 and IIID-1; Archipelagic Sea Lane Branch IIIE, which joins Archipelagic Sea Lane IIIA at point IIIA-2, for sailing from the Indian Ocean to the Sulawesi Sea or vice versa through the Sawu Sea, the Ombai Strait, the Banda Sea, the Seram Sea and the Maluku Sea, or for sailing from the Timor Sea to the Sulawesi Sea or vice versa through the Leti Strait, the Banda Sea, the Seram Sea and the Maluku Sea, or for sailing from the Arafura Sea to the Sulawesi Sea or vice versa through the Banda Sea, the Seram Sea and the Maluku Sea, of which the axis is the line that joins connecting points IIIA-2, IIIE-1 and IIIE-2.

It should be noted that a provision under the GR stated that the list could be amended and adjusted. The government will renew it routinely to improve and complete the shortcomings of the geographical coordinates of outer points drawing the archipelago baselines. In addition if there are new data or there are changes to the baselines, the list will be amended and adjusted accordingly.

\section{HUMAN RIGHTS}

\section{Republic of Indonesia, Government Regulation No. 2 of 2002 - "Procedures on Protection of Victims and Witnesses for Gross Violations of Human Rights"}

The GR provides that victims and witnesses of gross violations of human rights have the right to obtain protection from the law enforcer and security apparatus. The protection is rendered at the beginning of investigation process, prosecution and examination before the court.

The forms of protection include safeguarding personal safety, concealing identities, and the provision of court testimony without being seen by the accused.

Protection of victims and witnesses is rendered based on the discretion of the law enforcer and security apparatus, or request by the victims and witnesses. If a request is made, such request has to be addressed to the National Commission on Human Rights in the investigation phase; to the Attorney General Office at the prosecution phase; and to the Court at the examination phase. The request will be passed through the security apparatus by those institutions. Law enforcement and 
security apparatus upon receiving a request will verify the ground for such request and identify the form of protection necessary.

Protection will be terminated if the victims or witnesses submit a request for termination, the victims of witnesses die or, based on the decision of the law enforcer or security apparatus, the protection is no longer necessary .

The GR provides that victims or witnesses shall not be charged any fees for the protection rendered. The cost of protections is borne by the law enforcers or security apparatus.

\section{Republic of Indonesia, Government Regulation No. 3 of 2002 - "Compensation, Restitution and Rehabilitation for Victim of Gross Violations of Human Rights”,}

The GR provides for compensation, restitution and rehabilitation for victims of gross violations of human rights. ${ }^{25}$ Compensation is defined as money paid by the state if the perpetrator found guilty by the Court could not afford to pay compensation to the victims. The Court defines restitution as money paid by the perpetrator found guilty. Rehabilitation is defined as to rehabilitate a victim to his or her position, such as dignity, good name, position and other rights.

In the event the victim of gross violation of human rights has died, the heirs and successors are entitled to receive the restitution or compensation.

The state is required to provide compensation in the event the person responsible is unable to provide for the remuneration set by the court. The execution of payment will become the responsibility of the Ministry of Finance.

\section{JAPAN $^{26}$}

\section{JUDICIAL DECISIONS}

Detention of a Korean fishing boat engaging in the fisheries activities within the maritime area newly incorporated into the Japanese territorial sea following the adoption of straight baselines; Effect on the prior fisheries agreement of the new straight baselines for the delimitation of the territorial sea

\footnotetext{
25 Under Law 26 of 1999 the term "gross violation of human rights" consisted of crimes against humanity and genocide. The two are commonly referred to as "international crimes".

26 Contributed by Yakushiji Kimio, Ritsumeikan Asia Pacific University, member of the Study Group on Decisions of Japanese Courts Relating to International Law.
} 
X v. STATE OF JAPAN

\section{Supreme Court, 30 November $1999^{27}$ \\ Keishu [Supreme Court Reports: Criminal Cases] Vol.53 No.8 (1999) 1045; Hanrei Jiho [Law Cases Reports] No.1694 (1999)155; Hanrei Times [Law Times Reports] No.1017 (1999) 114}

Since the Hiroshima High Court, Matsue Branch reversed the original judgment and remanded the case to the Matsue District Court, X made a jokoku appeal to the Supreme Court, arguing that the decision of the Hiroshima High Court erred in its judgment with regard to the legality of the drawing of the straight baseline in question in this case as well as in the interpretation of the Korean-Japanese Fisheries Agreement [1965] and, therefore, the decision of the Hiroshima High Court violated article 98 (2) of the Japanese Constitution, which provides that the treaties concluded by Japan shall be faithfully observed. The Supreme Court dismissed the appeal on the ground that the object of the appeal was to argue a mere violation of laws and regulations even if the Appellant invoked the Constitution, and consequently that the argument did not constitute the statutory ground for jokoku appeal. ${ }^{28}$ However, the Supreme Court held as follows:

The original judgment (of the Hiroshima High Court) is to be duly approved, which held that the exercise of Japan's adjudicatory jurisdiction over an illegal act committed in the area concerned ${ }^{29}$ was not to be restricted by the Japanese-Korean Fisheries Agreement [1965] (the one before its nullification on 22 January 1999) ${ }^{30}$ since the maritime area in question where the accused was held to have engaged in fishing activities on 9 June 1997 in violation of article 3, paragraph 1, of the Law for Regulation of Fishing Operations by Foreign Nationals had been newly incorporated into the Japanese territorial sea since 1 January 1997, in accordance with articles 1 and 2 of the Law on the Territorial Sea and the Contiguous Zone [1996] and article 2, paragraph 2, of its Enforcement Order (Cabinet Order).

\section{Disqualification of a child born out of lawful wedlock but acknowledged by the father as his own in respect of child support allowance; Discrimination against a child born out of wedlock}

\footnotetext{
27 Through appeal from Hiroshima High Court, Matsue Branch, 11 September 1998, 8 AsYIL 154. See also the 15 August 1997 Decision of the Matsue District Court, Hamada Branch, 7 AsYIL 287.

${ }_{28}$ Article 405 of the Law of Criminal Procedure limits the compulsory grounds for jokoku appeal to the Supreme Court to a violation of the Constitution; a violation of a treaty has been deemed as a violation of an ordinary law enacted by the Diet.

29 The point where the fishing boat was seized was approximately 18.9 miles north-west of Hamada, Shimane Prefecture and had been outside the Japanese territorial sea until Japan adopted straight baselines for the delimitation of its territorial sea.

30 The Japanese-Korean Fisheries Agreement of 1965 was replaced by the new Japanese-Korean Fisheries Agreement, which was signed on 28 November 1998 and entered into force on 22 January 1999.
} 


\section{THE GOVERNOR OF KYOTO PREFECTURE v. X}

\section{Osaka High Court, 16 May 2000 \\ Shomugeppo [Monthly Bulletin on Law Suits] Vol.47 No.4 (2001) 917}

The Appellee (the plaintiff of the first instance) gave birth to a child out of lawful wedlock and was provided with a child support allowance by Kyoto Prefecture in 1987. However, the Appellant (the defendant of the first instance) decided to disqualify her for the child support allowance in September, 1995 for the reason that the child had been recognized by his father in January, 1994. Though she lodged an objection against this decision, the Appellant dismissed her claim. Then she brought her case before the Kyoto District Court for the annulment of the said decision.

Article 1 of the Child Support Allowance Law provides that the purpose of the Law is to promote children's welfare by providing children unsupported by their fathers with a child support allowance. For this purpose article 4, paragraph 1, of the Law obligates the local governor to provide any mother taking care of a child whose parents have dissolved their marriage or whose father is dead. Any mother taking care of children placed under a similar situation and defined as such by a cabinet order is also included in the beneficiaries of the child support allowance (article 4, paragraph 1, item 5). The Order for Enforcement of the Child Support Allowance Law defined the category of children qualified for child support allowance pursuant to the delegation of authority prescribed in article 4, paragraph 1, item 5, of the Child Support Allowance Law. According to article 1-2, item 3, of the said Order for Enforcement (before it was amended in accordance with the Cabinet Order No. 224 of $1998^{31}$ ) "any child who was conceived by the mother out of lawful wedlock (or under circumstances similar to de facto marriage although marriage is not registered)" qualifies for child support allowance "(except any child acknowledged by the father as his own)".

The Kyoto District Court held that the exception in parentheses that excludes "any child acknowledged by the father as his own" from any child who was conceived by the mother out of lawful wedlock was illegal and thus invalid, on the ground that the exception deviated from the scope of delegation of authority set forth under the Child Support Allowance Law, article 1 of which designated any child unsupported by his or her father as a beneficiary of the child support allowance.

Contrary to this, the Osaka High Court held that the said exception did not violate article 14 of the Constitution ${ }^{32}$ or did not manifestly deviate from or abuse the discretionary powers given to the government under the Child Support Allowance Law, given that the government was empowered under the Law to decide by its

\footnotetext{
31 The Cabinet Order No. 224 of 1998 deleted the words "(except any child acknowledged by the father as his own)" in article 1-2, item 3, of the Order for Enforcement of the Child Support Allowance Law.

32 Article 14 of the Constitution provides: "All of the people are equal under the law and there shall be no discrimination in political, economic or social relations because of race, creed, sex, social status or family origin."
} 
discretion the range of beneficiaries of the child support allowance among the children unsupported by their father or under a similar situation and that the living conditions of those children who were recognized by their father could be considered improved in the eyes of the law. In this litigation the Appellee (plaintiff) argued that the exception in question violated articles 2, 24 and 26 of the International Covenant on Civil and Political Rights (hereinafter referred to as the ICCPR), and article 2, paragraph 1, and article 26 of the Convention on the Rights of Child (hereinafter referred to as the CRC), as well as the Convention on the Elimination of Discrimination against Women. The Osaka High Court dismissed these arguments, holding as follows (in summary):

Since Japan has not ratified the Optional Protocol to the ICCPR and has not declared under article 41 of the ICCPR that it recognizes the competence of the Human Rights Committee (hereinafter referred to as the HRC) to receive and consider communications from other States Parties, its obligation under the ICCPR is limited to submitting reports set forth in article 40. The general comments [especially on articles 2 and $26^{33}$ in this case] have no binding force upon the States Parties and are expected to be referred to only as a guideline when they interpret and implement the ICCPR. In addition, the right to child support allowance in question is a social right and thus falls under the International Covenant on Economic, Social and Cultural Rights (hereinafter referred to as the ICESCR). Article 9 of the ICESCR does not require that States Parties recognize the right to social security as a concrete right to be realized immediately. Certainly, article 2, paragraph 2, requires a social right to be equally implemented. However, whether or not a specific social security system shall be established should be judged and decided, taking into account the economic and social conditions of the time as well as the general living conditions of citizens. Furthermore, in materializing a specific legislation on social security allowance, one cannot disregard the financial conditions of the State and such legislation needs complex and highly technical considerations for various issues to be solved. Therefore, choice and decision of particular legislation is left to a wide discretion of the Diet. The ICESCR declares that States Parties have political responsibility to positively promote their social security policy in order to realize the rights enumerated in the Covenant, and does not lay down that individuals be provided immediately with specific rights. Since the government did not manifestly deviate from or abuse its discretionary powers under the Child Support Allowance Law in this case, there is no violation of the ICCPR.

Though article 2, paragraph 1, of the CRC stipulates that States Parties shall respect and ensure the rights set forth in the Convention without discrimination of any kind, its article 26 [paragraph $2^{34}$ ] provides that the benefits should, where appropriate, be granted, taking into account the resources and circumstances of the child and persons responsible for the support of the child, as well as any other consideration relevant to an application for benefits made by or on behalf of the child. Thus the Convention does not require States Parties to provide all fatherless families

33 Added by the author.

34 Added by the author. 
uniformly with the right to the benefits of the child support allowance. The concluding observations of the Committee on the Rights of the Child concerning Japan's first report is of a nature of "suggestions and general recommendations" based on article 45 of the Convention and therefore has no legally binding force on the Japanese domestic jurisdiction. Furthermore, the said concluding observations say nothing about whether or not article 1-2, item 3, of the Order for Enforcement of the Child Support Allowance Law contravenes the Convention. Thus it cannot be held that this provision violates the CRC.

Since the child support allowance is not provided for female children in a discriminatory way, no problem arises in respect of the Convention on the Elimination of Discrimination against Women. ${ }^{35}$

\section{Sovereign Immunity of the Republic of Nauru and the Republic of Nauru Finance Corporation from the civil law jurisdiction of Japanese Courts; Waiver of the immunity made in the bond documents}

\section{KLESCH \& COMPANY LIMITED v. THE REPUBLIC OF NAURU FINANCE CORPORATION ET AL}

\section{Tokyo District Court, 30 November 2000 Hanrei Jiho[Law Times Reports] No.1740 (2001) 54}

The defendant, the Republic of Nauru Finance Corporation (hereinafter referred to as "RONFIN"), was created under the Republic of Nauru Finance Corporation Act in 1972. The plaintiff, Klesch \& Company Limited (hereinafter referred to as "Klesch"), is a privately owned British company created in 1990. On 27 July 1989, RONFIN issued bearer bonds called RONFIN Japanese Yen Bonds Series C (hereinafter referred to as Series C Bonds), having an aggregate face value of five billion yen. Another defendant, the Republic of Nauru, unconditionally secured the repayment of the principal of the Series $\mathrm{C}$ Bonds and its interest. Although the RONFIN Series C Bonds were originally due for repayment on 27 July 1994, by agreement of the original bondholders the maturity date was postponed stage by stage to 27 April 1995. However, RONFIN made no payment of the bond debt from 27 July 1994 and the bond became defaulted on 27 April 1995. Klesch purchased certain Series C Yen Bonds with a face value of one billion yen before the bonds were to have matured and registered its ownership of the Series C Bonds in Japan on 18 May 1995. Klesch filed suit against RONFIN and the Republic of Nauru for repayment of the bond debt on 1 June 1995. While RONFIN and the Republic initially refused

\footnotetext{
35 The Appellee made a jokoku appeal against this decision to the Supreme Court. The Supreme Court held on 31 January 2002 that the exception of article 1-2, item 3, of the Order for Enforcement of the Child Support Allowance Law was illegal and invalid on the ground that the stipulation deviated from the scope of delegation of authority set forth under the said Law. The decision says nothing about whether the said exception violates the ICCPR and CRC.
} 
to accept the service of a summons sent through diplomatic channels on the ground that RONFIN and the Republic were immune from Japanese courts' jurisdiction, RONFIN and the Republic asserted sovereign immunity under international customary law before the Tokyo District Court through their counsel.

Series C Bonds include commitments that any lawsuit against RONFIN may be filed with Tokyo District Court and other higher courts competent to accept appeals from Tokyo District Court to the jurisdiction of which RONFIN is to be unconditionally and irrevocably subject and that RONFIN unconditionally and irrevocably waives immunities it has and would have from the proceedings arising out of Series $\mathrm{C}$ Bonds debt and filed against it, including service, adjudgment, attachment and execution, to the extent that the applicable law permits. The Republic of Nauru made the same commitments in connection with its security of RONFIN's bond in the same Series C Bonds.

Tokyo District Court held that neither the Republic of Nauru nor RONFIN enjoys sovereign immunity from the jurisdiction of the court for the following reasons:

Both the Republic and RONFIN expressed explicitly their intention to submit to the jurisdiction of the Tokyo District Court in the proceedings relating to Series $\mathrm{C}$ Bonds as well as the intention to waive immunity from the proceedings in Japan including judgments on merits. The cause of this lawsuit relates to economic activities extensively and widely performed in the international society in these days. Furthermore, the intention to choose courts other than the Republic of Nauru's courts as competent courts to deal with disputes arising out of the Series C Bonds, as well as to waive immunity from the jurisdiction of such courts, is explicitly expressed in the clauses of commitments written in the said bonds. In these circumstances, the court cannot affirm that to give the foreign State and its organ immunity from the jurisdiction of domestic courts is required by customary rules of international law, which Japan shall observe as "established laws of nations" under article 98, paragraph 2, of the Constitution.

Having traced the historical development of the theory on immunity from the so-called doctrine of absolute immunity to that of restrictive immunity, as well as the recent tendency of national legislation and the European Convention of 1972 to adopt restrictive immunity, the Tokyo District Court concluded as follows:

Based on the economic nature of the cause of this claim, that is, the flotation of bonds secured by the government as well as the explicit waiver made in the commitment written in the bonds, the Court cannot accept the argument that the Defendants shall be immune from the jurisdiction of Japanese courts in the proceedings of this case according to customary international law on sovereign immunity. Therefore, the court need not consider whether or not RONFIN is a genuine State organ, the purpose of the flotation of the Series C Bonds and the other issues posed by the Defendants. 


\section{KOREA $^{36}$}

\section{JUDICIAL DECISIONS*}

\section{Recognition of Refugee Status and Its Legitimacy \\ Seoul Administrative Court, 16 August 2001 99Gu1990 Judgment}

\section{A.M.A.M. v. MINISTER OF DEPARTMENT OF JUSTICE}

1. The plaintiff was a foreigner holding an Iraqi passport. He entered Korea on 14 May 1995 after getting a tourist visa at the Korean embassy in Jordan. He worked at the city of Incheon before finally applying for refugee status to the Ministry of Department of Justice in accordance with Article 76, para. 2 of the Immigration Control Law of Korea.

The application for refugee status was however rejected by the Minister of Department of Justice on 30 December 1998 because the plaintiff could not prove the condition of a 'well-founded fear of being persecuted' as laid down at Article 1 of the 1951 Convention relating to the Status of Refugees (hereinafter, The 1951 Convention).

The Plaintiff then instituted a lawsuit against the Minister of Department of Justice for revoking the decision of not granting refugee status.

2. Decision on 'Well-Founded Fear of Being Persecuted'

The 1951 Convention defines a 'refugee' as a person who 'owing to a wellfounded fear of being persecuted for reasons of race, religion, nationality, membership of a particular social group or political opinion, is outside the country of his nationality and is unable or, owing to such fear, is unwilling to avail himself of the protection of that country; or who, not having a nationality and being outside the country of his former habitual residence as a result of such events, is unable or owing to such fear, is unwilling to return to it'. ${ }^{37}$ In this case whether the plaintiff had a 'wellfounded fear of being persecuted' in his country was the most controversial question.

Since Saddam Hussein took office on 16 July 1979, the domestic and human rights situation in Iraq had been serious; many people were illegally arrested, tortured and confined under his dictatorial rule.

The Plaintiff contended that he had carried out anti-government activities including the distribution of printed matters and criticizing the Hussein regime as a member of a secret student organization of Baghdad University which was a sub-organ of

\footnotetext{
36 Contributed by Eric Yong-Joong Lee, Assistant Professor, Seoul National University College of Law, Korea.

* Contributed by Eric Yong-Joong Lee, Dongguk University College of Law, Korea

37 Art. 1(A) of the 1951 Convention. This definition was slightly expanded at the meeting of the Organization of African Unity in 1969, but its substance still revolves around the concept of political defection. For details, see P. Kourula, Broadening the Edges: Refugee Definition and International Protection Revisited (The Hague: Kluwer Law International, 1997), pp. 49-62.
} 
the Kurd Democratic Party. He also asserted that he participated in an anti-Hussein demonstration around March 1991. If the insistence of the Plaintiff was true, he should have been arrested and punished by the Iraqi government. If the Plaintiff was a member of anti-government organization involved in anti-Hussein activities he would have been watched by the secret police of Iraq. However, the Plaintiff completed military service between September 1988 and May 1991 and obtained a passport for emigration without any difficulties.

The Plaintiff also contended that he was severely discriminated against by the Iraqi government because he is a Kurd. He maintained that he was arrested at a park by the police while dating his girl friend when he was a senior college student. At the police station, he was tortured and threatened just because he was a Kurd. Although Kurds were actually not in a good position in Iraq, they were not severely discriminated against if they did not directly participate in the liberation movement.

3. The Plaintiff did not go back to Iraq even after the term of validity of the passport had expired. He then altered the term on the passport illegally. However, despite his insistence, there is no clear evidence that would prove that the Plaintiff was involved in the liberation movement of the Kurds and took part in anti-Hussein regime activities. Considering that the Plaintiff graduated from Baghdad University and was granted a veterinarian license as well as serving in the military forces of Iraq, he was presumably not persecuted due to his ethnic origin.

4. The Plaintiff did not therefore have a 'well-founded fear of being persecuted' as laid down at Article 1 of the 1951 Convention. Therefore, the Plaintiff could not be regarded as a refugee under Article 2(2)(2) of the Immigration Control Law. Following this reasoning the Court turned down the Plaintiff's request for cancelling the original decision of the defendant regarding the non-granting of refugee status.

\section{Direct Application of Treaty}

\section{Supreme Court, 22 October 2002, 2002Da32523, 32530 Judgment}

\section{ARAH MARINE CO. v. MARINE JEWELRY}

1. The so-called contracting carrier who made the transportation contract with passengers, senders or their representatives according to the Warsaw Convention for the Unification of Certain Rules Relating to International Carriage by Air as amended at The Hague of 1955 (hereinafter, the Warsaw Convention), and who mandated its implementation to the actual carrier is a carrier under the Warsaw Convention.

Considering that the Plaintiff made the transportation contract with the Defendant to convey the freight from the Kimpo airport of Korea to Los Angeles airport, issued the transportation invoice and then made a separate air transportation contract with Asiana airlines co. for the transportation of goods, the transportation of freight in this case is the international air transportation under the revised Warsaw Convention and the Plaintiff is the transporter in the contract. Therefore, it is right 
that the revised Warsaw Convention is applied to the contract between the Plaintiff and the Defendant. The reason for appeal is unacceptable.

2. Pursuant to Article 19 of the revised Warsaw Convention, the transporter is responsible for the damage occasioned by delay in the carriage by air of passengers, luggage or goods. In this case, the damage occasioned by delay covers not only the damage in the course of air transportation as laid down in Article 18, para. 2 of the revised Warsaw Convention, but also the damage which occurred through delay caused by the late loading of baggage or freight. In addition, Article 26 of the revised Warsaw Convention states that "in the case of delay the complaint must be made at the latest within twenty-one days from the date on which the baggage or cargo have been placed at his disposal. Failing complaint within the times aforesaid, no action shall lie against the carrier, save in the case of fraud on his part."

The Supreme Court accepts that the original decision is right for the following reasons: Due to the accumulation of export freight, the transportation contract-making between the Plaintiff and the Asiana Airlines Co. was delayed. Accordingly, the freight was transported one day later than the date on the first document of carriage and five days later than the date on the second document of carriage of the Plaintiff. As a consequence, the responsibility of the damage compensation of the Plaintiff was extinct.

3. This court shall reject the appeal.

\section{Cancellation Conditions for Foreign Arbitration Decision}

\section{Supreme Court, 16 February 2003, 2001Da 77840 Judgment}

\section{YOU HOON-KEUN v. MAJESTIC WOODCHIPS INC.}

The following is the original decision. Donghae Pulp Co. and the Defendant Majestic Woodchips Inc., established under the state law of Louisiana of the United States, made a contract in 1994 that the Defendant would provide pieces of wood for making pulp, the raw material for paper. The two sides agreed to settle the disputes relating to the contract by Korean law and the Rules of Conciliation and Arbitration of the International Chamber of Commerce.

When a dispute arose between the Defendant and Donghae Pulp Co. regarding the implementation of the aforesaid contract, the Defendant and its domestic branch, TKT Co., called for arbitration. Following the request, the arbitration court appointed Neil Kaplan (living in Hong Kong) as the arbitrator on 4 August 1996 and decided Singapore as the arbitration region. The arbitrator filled out the Terms of Reference stating the arbitrator can change the arbitration region and that the arbitration will be processed by the national laws in force of the arbitration region and the Rules of Conciliation and Arbitration of the International Chamber of Commerce as amended on 1 January 1988. The parties concerned signed the Terms of Reference. Afterwards, the arbitrator changed the arbitration region to Hong Kong and conducted the arbitration proceedings there. On 14 July 1998 the arbitrator decided that Donghae 
Pulp Co. should compensate the damage of the Defendant as it had violated the contract.

According to the original judgment, this arbitration case is not a domestic award under the arbitration law because this is the judgment made in Hong Kong concerning a commercial dispute. Thus, the New York Convention on the Recognition and Enforcement of Foreign Arbitral Awards (hereinafter, New York Convention) in which Korea and United States have joined should be applied for the recognition and enforcement of this arbitral award.

Article 5, para. 1(e) of the New York Convention stipulates the cancellation of the award as a reason for refusing the recognition and the enforcement of the arbitration award. Following this regulation, the arbitration award shall be cancelled by the country in which that award was made or the competent authority of the country under the law of which that award was made. In this case, by the way, Donghae Pulp Co. and the Defendant agreed merely to resolve the disputes regarding the abovementioned contract by arbitration. However, they did not clearly agree on the standard law of the arbitration process, but agreed only to follow Korean law and the Rules of Conciliation and Arbitration of the International Chamber of Commerce. Pursuant to Article 11 of the Rules of Conciliation and Arbitration of the International Chamber of Commerce and in conformity of the parties concerned, the arbitrator decided the laws in force of the arbitration region and the Rules of Conciliation and Arbitration of the International Chamber of Commerce as the standard laws. Because Hong Kong laws in force and the Rules of Conciliation and Arbitration of the International Chamber of Commerce were mainly applied in the arbitration process, the Korean court is not a competent authority.

This court shall reject the appeal.

\section{Constitutionality of the Present Extradition Procedure Constitutional Court, 30 January 2003, 2001 HunBa95 Decision}

Claimant: KANG, X K.

\section{Re-appeal to the Supreme Court's Decision (2001MO272) regarding extradition permission}

The claimant was a Korean-American citizen who was indicted for rape and other crimes by the State Court of California and was found guilty by the verdict of juries in February 1999. He fled from the United States into Korea on 1 March 1999 just before the final adjudication of the State court and was finally sentenced to 271 years' servitude at the California court. On 4 June 2001, the US Department of Justice required the extradition of the claimant. Accordingly, the Seoul High Prosecutor Office referred the matter regarding the extradition of the claimant to the Seoul High Court, and that Court permitted the extradition on September 25, 2001. The claimant re-appealed to the Supreme Court against this decision, but the Supreme Court denied 
his appeal again. Then the claimant applied for the examination of the constitutionality of Article 3 of the Extradition Law ${ }^{38 *}$ to the Constitutional Court.

The following were the assertions of the claimant. The provision of this case regulates the single-trial system; this would pursue the public interests as does transnational cooperation, through obtaining the quick investigation and adjudication procedure for criminals. However, the single-trial system would give the claimant a heavy psychological burden as well as block the possibility of re-trying the decision from the beginning. Thus, this regulation will not be consistent with the principles of the Constitution regarding Dignity, Pursuit of Happiness (Article 10), Personal Liberty and Integrity and Due Process of Law (Article 12, paragraph 1), Right to Trial (Article 27, paragraph 1) and No Infringement of Essentials (Article 37, paragraph 2).

The Constitutional Court's decision was as follows. The Extradition Law applies the Criminal Procedural Law with appropriate modification; grants the claimant the right to ask for the aid of a lawyer; gives the accused a chance to express a personal opinion; and allows extradition to be denied when necessary. Although the Extradition Law regulates a single-trial system, it is undeniable this process has the rationality and legitimacy that the due process of law generally requires. Moreover, the extradition examination is a measure of international judicial cooperation. It is one of the procedures for deciding the extradition of a criminal following the request of a foreign country which has entered into an extradition treaty with Korea. The principle of reciprocity is strictly observed in this process.

The Extradition Law has several regulations which prevent unjust extradition or an extradition that involves human rights violation. Considering all the statements, the single-trial system as laid down in Article 3 of the Extradition Law does not imply a limitation on the dignity and fundamental freedom of citizens. Thus, the Constitutional Court decided that there was no violation of relevant Constitutional regulations.

Conclusively, Article 3 of the Extradition Law was not unconstitutional.

\footnotetext{
38 * It reads: "The Seoul High Court and the Seoul High Prosecutor Office shall have the executive jurisdiction over the case regarding the extradition examination and the request concerned."
} 


\section{MALAYSIA $^{39}$}

\section{JUDICIAL DECISIONS}

\section{Enforcement of Foreign Judgment}

[2002] 7 MLJ 703

BANQUE NATIONAL DE PARIS v. TING KAI HOON ${ }^{40}$

[2002] 2 MLJ 353

\section{COMMERZBANK (SOUTH EAST ASIA LTD) v. TOW KONG LIAN ${ }^{41}$}

The enforcement of foreign judgements in Malaysia can take place in two ways: either by using the principles of common law or through the Reciprocal Enforcements of Judgments Act $1958^{42}$ (REJA).

Both of these cases concern the statutory enforcement of foreign judgments. The REJA lays down the rules with which a party can enforce a foreign judgment here. This is done basically by registering the foreign judgment in Malaysia. The foreign judgment is then treated as if it is a Malaysian judgement and enforcement is done accordingly.

Naturally, there are defences to the enforcement of foreign judgments. ${ }^{43}$ The party against whom the judgment is being carried out can, for example, claim that the initial case heard in the foreign court was not valid as it did not have the original jurisdiction to hear the case in the first place; otherwise, the party can even argue that the enforcement of the foreign judgment would be contrary to Malaysian public policy. $^{44}$

In the cases of Banque National de Paris v Ting Kai Hoon and Commerzbank (South East Asia Ltd) v Tow Kong Lian the defendants were both Malaysians trying to stop a Singaporean judgment enforced against them in Malaysia. They both tried to use the provisions in the REJA to achieve this, but with different levels of success. $^{45}$

${ }^{39}$ Contributed by Azmi Sharom, Associate Professor, University of Malaya, Faculty of Law

40 [2002] 7 MLJ 703.

41 [2002] 2 MLJ 353.

42 Revised in 1972. Act 99.

43 In particular sections 5 and 6 of REJA.

${ }^{44}$ There are of course other justifications in REJA which can be used not to enforce a foreign judgment.

${ }^{45}$ In both cases there were several lines of argument to justify their application. However, for the purpose of this survey, only the points with greatest relevance to Conflict of Laws principles will be discussed. 
In Banque National de Paris the Defendant argued that the Singaporean judgment should not be enforced in Malaysia based primarily on two grounds: firstly because the Singaporean judgment was void for uncertainty, and secondly, because to enforce the judgment would be against Malaysian public policy.

Regarding the first line of argument, the judge held that when a foreign judgment is registered in Malaysia, it is treated as though it is a Malaysian judgment. It does not become a Malaysian judgment. Therefore any judgment on the actual merits of the case would have to be sought in the court where it was heard, in this case, the Singaporean court.

On the grounds of public policy, the Defendant had argued that the Plaintiffs, by offering credit facilities to the Defendant, acted unlawfully in that they had breached the rules of Exchange Control Act $1953^{46}$ and the Banking and Financial Institutions Act $1989 .{ }^{47}$ The judge found both arguments to be without merit. The Defendant's application was thus dismissed.

In the Commerzbank case the Defendant tried to get out of the foreign judgment by arguing that the Singaporean court had no original jurisdiction to hear the case and the enforcement of the foreign judgment would be against Malaysian public policy. With regard to the matter of jurisdiction, the Defendant relied on section 5(2)(a)(i) of REJA which states that for the foreign court to be deemed to have had jurisdiction to hear the case, then the Defendant must have submitted to its jurisdiction. This the Defendant did not do and the Singaporean judgment was given in default.

However, the judge was not convinced of this argument because the Defendant, in the guarantee to the loan being made, had agreed to the Singapore courts' being the proper forum to determine any problems that may arise. He had therefore contractually submitted to the Singapore Court's jurisdiction and his non-appearance made no difference to this. ${ }^{48}$

But the Defendant in Commerzbank was successful in his claim that to enforce the Singaporean judgment would be contrary to Malaysian public policy. This argument was accepted because the service of writ for the trial on the Defendant by the Singapore court was not carried out according to the procedure laid out by Malaysian law.

There are two ways to serve a writ in Malaysia in situations where the case is being heard in a foreign jurisdiction. A letter of request from the court or foreign tribunal requesting service upon a person in Malaysia must be received by the Minister who then sends it to the High Court with a request that this service take place. Alternatively, where there is a Civil Procedure Convention between the foreign

\footnotetext{
46 Revised 1969. Act 17.

47 Act 372.

48 It is strange that the Defendant tried this line of argument because in section 5(2)(a)(iii) of REJA it clearly states that a foreign court will be deemed to have jurisdiction "if the judgment debtor, being a defendant in the original court, had before the commencement of the proceedings agreed, in respect of the subject matter of the proceedings to submit to the jurisdiction of that court or of the courts of the country of that court".
} 
country and Malaysia, the request may be made directly to the registrar by way of a request from a consular or any other authority of that foreign country.

Neither of these procedures was followed; by serving its writ on the Defendant with no heed to the procedures of Malaysian law the Singapore Court had acted in a way that was contrary to the sovereignty of Malaysia and thus as a matter of public policy the case following the wrongful service of writ could be neither recognized nor enforced in Malaysia.

\section{SOVEREIGNTY OVER PULAU LIGITAN AND PULAU SIPADAN ${ }^{49}$}

On 17 December 2002 the International Court of Justice (ICJ) delivered its judgment in the case concerning Sovereignty over Pulau Ligitan and Pulau Sipadan (Indonesia) Malaysia). The facts of the case can be summarized as follows. Pulau Ligitan and Pulau Sipadan are two islands located in the Celebes Sea off the north-east coast of the island of Borneo. Ligitan is uninhabited whilst Sipadan has a scuba diving resort on it. Both Indonesia and Malaysia claimed sovereignty over the islands.

On 2 November 1998, the two countries notified the Registrar of the Court that a Special Agreement between the two States was signed on 31 May 1997 and came into force on 14 May 1998. According to this Agreement, Malaysia and Indonesia agreed to have their dispute settled by the ICJ. Hearings were held from 3 to 12 June 2002.Indonesia's claims were based on three grounds:

a. A Convention concluded between Great Britain and the Netherlands in 1891 (the 1891 Convention) had defined the boundaries for British and Dutch territories and the islands that fell within the Dutch area. Upon Independence from Holland, Indonesia would therefore inherit those islands.

b. In the alternative, they claim sovereignty over the islands as successors to the Sultan of Bulungan who possessed authority over the islands and who had contracted the islands to the Dutch.

c. A series of effectivites or activities which express an interest on the control of these islands have been conducted by the Dutch and Indonesian governments.

Malaysia's claims were based on two grounds:

a. Sovereignty over the islands were obtained through the transmission of title from the Sultan of Sulu, to Spain, to the United States of America, to Great Britain on behalf of the State of North Borneo, to the United Kingdom of Great Britain (when North Borneo became a colony) and then finally to Malaysia when North Borneo became part of Malaysia.

b. A series of effectivites or activities which express an interest on the control of these islands have been conducted by the British and Malaysian governments.

\footnotetext{
49 Judgment obtained from the International Court of Justice website, http://212.153.43.18/icjwww/ icj002.htm
} 
The decision of the ICJ, with 16 votes for Malaysia and one against is as follows: With regard to the 1891 Convention, the Court held that the Indonesian government was mistaken in its interpretation of the treaty, namely Article IV which reads:

From 4'10" north latitude on the east coast the boundary-line shall be continued eastward along that parallel, across the Island of Sebittik: that portion of the island situated to the north of that parallel shall belong unreservedly to the British North Borneo Company, and the portion south of that parallel to the Netherlands.

The Indonesians contended that the boundary line extended into the ocean and seeing as Sipadan and Ligitan were south of the parallel 4'10", it therefore belonged to Indonesia as an inheritance from the Netherlands.

Having examined the object and purpose of the 1891 Convention, the ICJ held that it was of the opinion that the Convention was about the delimitation of the boundaries between the parties' possession within the island of Borneo itself and it could not find anything to suggest that the parties intended to delimit the boundary between their possessions to the east of Borneo and the island of Sebatik or to determine the sovereignty of any other islands.

With regard to the alternative ground that Indonesia inherited the islands from the Dutch who had contractually acquired them from the Sultan of Bulungan, it was held that the contract referred to mentions the islands of Nanukan and Sebatik, and the islets belonging thereto. The Court was reluctant to include within the definition of "islets" Sipadan and Ligitan which are 40 nautical miles away.

The ICJ was equally dismissive of the Malaysian historical claims on the islands. The supposed succession of the islands depended on their belonging to the Sultan of Sulu in the first place. This was not proved to the Court's satisfaction and it held that in all relevant documents, reference was never made to the two islands by name. Instead the Sultanate of Sulu was described as "the Archipelago of Sulu and the dependencies thereof" or "the Island of Sooloo with all its dependencies".

In the Protocol with Spain $^{50}$ where the Sultan of Sulu transferred title of his lands, again there was no mention of the two islands and there is no evidence that Spain considered Ligitan and Sipadan to be part of the agreement. Going further down the chain of succession from Spain to the United States to Britain, the Court found that there could be no certainty that the islands were part of the agreements.

The ownership of the islands was therefore decided on the effectivites. ${ }^{51}$ The Court did not accept the Indonesian claims that their activities which included navy patrols (by the Dutch navy and Indonesian navy), along with the activities of

\footnotetext{
${ }^{50}$ Protocol between Spain and Sulu Confirming the Bases of Peace and Capitulation of 22 July 1878.

${ }^{51}$ The dissenting judge, Judge Franck, who was appointed by Indonesia, described making a decision based on the effectivites as akin to trying to guess the weight of a handful of grass and a handful of feathers. He decided in favour of Indonesia maintaining that the 1891 Convention, in delimiting the entire frontier between Britain and Holland, had established a line intended to ensure that future conflicts over territory do not occur. This would logically include islands in the area.
} 
Indonesian fishermen on the islands, were sufficient to establish sovereignty. The Court instead was impressed with the Malaysian effectivites which were, although modest in nature, diverse in character, including legislative, administrative and quasijudicial acts and covering a considerable period of time that shows a pattern which reveals an intention to exercise State functions with respect to the two islands. These activities included control over the taking of turtle eggs, allegedly the most important economic activity on Sipadan for many years, the establishment in 1933 of a bird sanctuary on Sipadan, and the construction and maintenance of lighthouses on both islands in the 1960s. Furthermore, when these activities were carried out, there was no protest from either the Dutch or subsequently the Indonesian governments. Ligitan and Sipadan were declared as falling within Malaysian sovereignty.

\section{NATIONAL LAWS ON INTERNATIONAL LAW MATTERS}

\section{Anti-Personnel Mines Convention Implementation Act 2000}

\section{Act 603}

This is an act to implement the Convention on the Prohibition of the Use, Stockpiling, Production and Transfer of Anti-Personnel Mines and on their Destruction 1997 (Mine Ban Treaty) which Malaysia acceded to on 22 April 1999 and which came into force for the nation on 1 October 1999.

The act basically bans the use of anti-personnel mines. ${ }^{52}$ This includes the placing of mines, the development and production of mines and the possession of mines. ${ }^{53}$ There are exceptions ${ }^{54}$ for the purpose of training or when possession is for the purpose of disarming the mines. Any mines in Malaysia which are stockpiled, laid or surrendered will be destroyed.

In the event there is an international fact finding mission sent to Malaysia (as authorized under Article 8 of the Mine Ban Treaty), a certificate shall be issued to each member of the fact-finding mission, stating their identity, status, immunities, privileges and any conditions applicable to the mission. ${ }^{55}$ The fact finding mission may be accompanied by the Malaysian police or the military ${ }^{56}$ when conducting

\footnotetext{
52 Which is defined in section 2 as "a mine that is designed to be exploded by the presence, proximity or contact of a person and that is capable of incapacitating, injuring or killing one or more persons; but a mine that is designed to be detonated by the presence, proximity or contact of a vehicle as opposed to a person, and that is equipped with anti handling devices, is not considered to be an anti-personnel mine as a result of being so equipped."

53 Section 3.

54 Section 4.

55 Section 10.

56 Section 13.
} 
their work which is fundamentally limited to inspection of premises which are relevant to determining compliance with the treaty. ${ }^{57}$

Search warrants can be issued by magistrates if there is reasonable cause to believe there are premises where activities in contravention of the treaty are being conducted, to enable a fact-finding mission to carry out its duties or if necessary information is believed to be available in the premises. ${ }^{58}$ However, if a police officer not below the rank of Inspector is convinced that evidence would be destroyed if the procedure for obtaining a warrant is followed, then the premises may be entered without one. ${ }^{59}$

If there is no specific provision for penalties, then the general penalty for committing an offence under this act is a fine not exceeding RM 20000 or a five-year prison sentence or both.

NEPAL $^{60}$

\section{JUDICIAL DECISIONS}

\section{Rights of the Child - Registration of an Association - UN Convention on Rights of the Child}

TILOTAM POUDYAL v. HMG MINISTRY OF HOME AND OTHERS

\section{Writ Petition No. 174 of 2000 decided by a Full Bench of the Supreme Court of Nepal on 19 July 2001}

The petitioner and other persons were minors while applying for registration of a Non-Governmental Organisation (NGO) named "Children Awakening Club Nepal" (Jagriti Bal Club Nepal) before the District Administration Office, the concerned authority to register NGOs. The petitioner master Tilotam Poudyal and his friends had applied before the Nawalparasi District Administrative Office for registration of the Children Awakening Club Nepal (hereinafter Club) in early 1997. The District Administration Office had asked for directions from the Ministry of Home regarding registration of an NGO where the applicants were minors. The Home Ministry decided in December 1997 that only citizens were eligible for registering an NGO under the

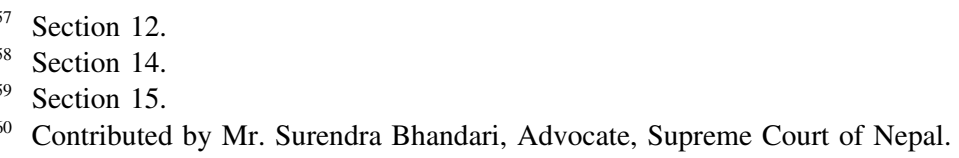


Association Registration Act, 1978..$^{61}$ The Home Ministry noted that the applicants were minor and had not attained the age for obtaining citizenship and therefore were not eligible to register an NGO in their name and directed the District Administration Office Nawalparasi to deny the registration of NGO to minors.

The petitioner applied to the Supreme Court of Nepal in early 1998 for issuance of writs of certiorari and mandamus to quash the decision of Ministry of Home and direct the District Administrative Office Nawalparasi to grant registration of the proposed NGO. The Division Bench of the Supreme Court of Nepal decided the case in November 2000. The judges of the Division Bench forwarded the matter to the Full Bench which unanimously decided it in July 2001.

There were the following legal questions to be decided by the court:

i. Whether minors are eligible to register an NGO

ii. Whether the Ministry of Home was free to give discriminatory decisions

iii. Whether the denial of registration of a NGO to minors showed disrespect to the UN Convention on the Rights of Child.

The Full Bench of the Supreme Court of Nepal ${ }^{62}$ decided that the minors are also citizens of Nepal capable of obtaining a citizenship certificate through a legal process and could not be discriminated against in exercising those rights conferred on citizens by any law only because they are minors. The domestic laws of Nepal, particularly the Association Registration Act, 1978, cannot restrict the right to association granted by the Constitution of the Kingdom of Nepal as a fundamental right. Moreover, Nepal was a party to the UN Convention on the Rights of the Child, 1989, which under Section 9 of the Treaty Act, 1990 of Nepal, prevails over conflicting domestic laws. Article 15 of the UN Convention on the Rights of Child ${ }^{63}$ requires Contracting Parties to provide the right of association to children without any discrimination. The Ministry of Home had also permitted minors to register an NGO in

\footnotetext{
${ }^{61}$ The Association Registration Act, 1978 and Association Registration Rules, 1979 do not prescribe that only the citizens are eligible for registration of an association but Article 12 (2) of the Constitution of the Kingdom of Nepal prescribes that all the citizens shall have rights including freedom to assemble peaceably and freedom to form unions and associations. Further the Association Registration Act does not discriminate between minor and the persons who have attained age. The Citizenship Act of Nepal, 1964 and Citizenship Rules 1992 do not impose any condition or limitation of age for citizenship. However, according to the Children Act, 1992 those are "children" who have not attained sixteen years of age.

${ }^{62}$ The Full Bench was composed of Justice Kedar Nath Upadhyaya, Justice Kedar Nath Acharya and Justice Rajendra Raj Nakhwa.

63 Article 15 of the UN Convention on the Rights of Child provides:

1. States Parties recognize the rights of the child to freedom of association and to freedom of peaceful assembly.

2. No restrictions may be placed on the exercise of these rights other than those imposed in conformity with the law and which are necessary in a democratic society in the interests of national security or public safety, public order (ordre public), the protection of public health or morals or the protection of the rights and freedoms of others.
} 
Kathmandu District Administration Office in 1995. The Ministry could not make discriminatory decisions for minor registration of an NGO inside and outside Kathmandu. Therefore, the decision of the Ministry was inconsistent with Article 11 (1) and $(2)^{64}$ of the Constitution of the Kingdom of Nepal, 1990 and Article 15 of the UN Convention on the Rights of the Child. On these grounds the Supreme Court invalidated the decision of the Ministry and directed it to register the proposed NGO.

\section{Right to Clean Drinking Water - Compliance with WHO Standards}

\section{ADVOCATE PRAKASH MANI SHARMA v. DRINKING WATER CORPORATION NEPAL AND OTHERS}

\section{Writ Petition No. 2237 of 2000 decided by Division Bench of the Supreme Court of Nepal in June 2001}

The petitioner had filed a public interest litigation before the Supreme Court of Nepal asking for the issuance of a Writ of Mandamus against the respondent Nepal Drinking Water Corporation ordering it to provide clean drinking water to the consumers. The petitioner claimed that the drinking water distributed by Nepal Drinking Water Corporation, which is responsible for distribution of clean drinking water under Drinking Water Corporation Act, 1989, was below the standards prescribed by the WHO. Due to the consumption of unhygienic water common people suffered from many types of diseases. The activities of the respondent had therefore seriously affected the right to live in a clean and healthy environment. The respondent Drinking Water Corporation denied the claim of the petitioner stating that it was distributing water to the consumers in compliance with WHO standards.

There were the following legal questions to be decided by the court:

I. Whether the Drinking Water Corporation was responsible to supply clean drinking water

II. Whether the court could exercise jurisdiction to examine evidences in Public Interest Litigation to verify the contentions between the parties to the case

III. Whether the WHO Standards would apply as mandatory rules.

The Division Bench ${ }^{65}$ of the Supreme Court of Nepal decided the case in June 2001. The Supreme Court of Nepal acknowledged that the petitioner and the defendant had made opposing statements regarding the quality of the drinking water and

${ }^{64}$ See Constitution of the Kingdom of Nepal, (1990). Article 11(1) of the Constitution provides, "All citizens shall be equal before the law. No person shall be denied the equal protection of the laws." Article 11 (2) provides, "No discrimination shall be made against any citizen in the application of general laws on grounds of religion, race, sex, caste, tribe or ideological conviction or any of these."

${ }^{65}$ The Bench was composed of Justice Kedar Nath Acharya and Justice Bhairab Prasad Lamsal. 
therefore there was a need to verify the contentions. However, the Court denied examination of any evidences while exercising extraordinary jurisdiction in a public interest litigation case; however, the court received the WHO Standards and the Report of Institute of Medicine, Tribhuvan University. The Court did not specifically speak about the legal validity of the WHO Standards but said that the Drinking Water Corporation was an autonomous body that was not required to act upon the direction of anyone. However, the Court directed to the Drinking Water Corporation to realize the objectives of a Welfare State and to be aware of the responsibility of the Corporation to provide clean drinking water to the consumers. The Court denied issuing the Writ Petition.

\title{
PAKISTAN $^{66}$
}

\section{JUDICIAL DECISIONS}

\section{Private International Law}

Execution and enforcement of decrees passed by foreign court within Pakistan.

\author{
MUNAWAR ALI KHAN (APPELLANT) v. MARFANI AND CO. LTD \\ (RESPONDENTS)
}

\section{High Courts of Appeal Nos. 76 to 79 of 1995. Case Heard on 20 August 2002}

In 1989, the Respondents filed a suit against the Appellants claiming that the Appellants had agreed to sell and the Respondents had agreed to purchase an immovable property in central London. A number of ancillary charges were to be provided by the Appellants as part of the sale. The Appellants failed to provide for these service charges, despite the sale of the property having been completed. The respondent company filed a suit in London, and the writs of summons were issued to the Appellants, all of whom were resident in Pakistan.

The Appellants did not submit to the jurisdiction of the trial court in London and the Respondents' suits were decreed upon. One of the Appellants responded to the summons seeking further time to prepare his arguments, but did not appear on the date of the hearing. A subsequent application by the Appellants for the setting aside of the order was dismissed on 6 July 1990. A subsequent appeal by the Appellants was also dismissed in July 1991. In a subsequent ruling in August 1995 a court ordered the execution of the aforementioned orders.

${ }^{66}$ Contributed by Javaid Rehman, Professor of International Law, University of Ulster, UK. 
In the present case before the High Court of Justice in Karachi, the Appellants were challenging the order of enforcement and execution of judgment as pronounced by the English court on the basis that:

(a) the foreign judgment was not pronounced by a Court of Competent jurisdiction as provided by S.13(a) of the Civil Procedure Code (V of 1908).

(b) notwithstanding the fact that one of the Appellants did respond to the summons served upon him, none of the Appellants submitted to the jurisdiction of the English court.

The counsel for the Appellants argued that the judgment of the United Kingdom court was unenforceable, when the aforementioned exception to S.13 is taken into account. The counsel argued fervently before the court that the mere fact that the cause of action according to the procedural law of the country arose within its territorial jurisdiction should be of little significance in determining whether such Court had jurisdiction to deal with the matter. The counsel also relied upon Cheshire and North on Private International Law (13th Edition) where the authors note at p. 420:

According to the decisions that have dealt with the matter up to the present, it is undoubted that the various circumstances considered above exhaust possible cases in which foreign Court possesses international competence. Thus it is not sufficient that the cause of action, as for instance a breach of contract or a commission of a tort accrued in foreign country.

The counsel for the Respondents argued that the once the courts in the United Kingdom had exercised jurisdiction, the decision of the court should be treated as conclusive and binding. It was not disputed that the cause of action of accrued within a foreign jurisdiction where the contract between the parties had been entered and payment had to be made by the Appellants. The Respondents further relied upon Order 11, Rule 1 of the Supreme Court Rules whereby the United Kingdom courts could exercise jurisdiction over non-resident foreigners in matters where the cause of action accrued within their jurisdiction. The instant case summons were served upon the Appellants one of them, having responded to the same, sought additional time, but in the end failed to appear on the date of the hearing.

After detailed examination of the case-law and the arguments from the learned counsels for the Appellants the Court made the following pronouncements:

(a) having regard to the existing legislation namely S.13(a) of the Civil Procedure Code ( $\mathrm{V}$ of 1908) an action on the basis of a foreign judgment could only be maintained if the defendant in the aforesaid judgment was a resident or at least physically present in the foreign country at the time of commencement of proceedings or had submitted to or had agreed to submit to the jurisdiction of such foreign Court. The mere fact that the cause of action had accrued within the jurisdiction would not confer competence upon such Court in an international sense so as to make its judgments recognisable and enforceable in Britain. 
(b) A distinction needs to be drawn in instances where the defendant has appeared before a foreign court only to protest against assumption of jurisdiction vis-à-vis those situations where he takes up defences on the merits of the case or applies to have a default judgment set aside and appeals to the merits of such claims. In view of the court, while the latter instances were examples of submission and acknowledgement of the court's jurisdiction, the former could not be so regarded. The present case fell in the former category, whereby there was a failure on the part of foreign court to successfully assume jurisdiction.

(c) The application of S.13(a) of the Civil Procedure Code (V of 1908) would prima facie lead to an anomalous situation in that a decree of a Court in United Kingdom which is directly executable as a decree of a District Court in Pakistan may become unexecutable merely because that Court was not considered to possess jurisdiction in an 'international' sense notwithstanding the fact that under its own system of laws it had full powers to pass such decree. The High Court of Karachi directed that a copy of the judgement highlighting the present anomalous situation be presented to the Secretary, Ministry of Law Government of Pakistan and Secretary Pakistan Law Commission to consider the desirability of amending the relevant provisions of the Civil Procedure Code (V of 1908) in the light of anomalies as highlighted by the Court.

In the light of the aforementioned considerations, the High Court of Karachi allowed this appeal. The Court did not make any order as regards costs. Copies of the judgment were sent out respectively to the Secretary, Ministry of Law Government of Pakistan and to the Secretary, Pakistan Law Commission for a review and amendment of the relevant provisions of the Civil Procedure Code (V of 1908).

\section{PHILIPPINES ${ }^{67}$}

\section{JUDICIAL DECISIONS}

\section{Extraditee's right to bail; when exceptions to no-bail rule apply}

GOVERNMENT OF THE UNITED STATES OF AMERICA, represented by the Philippines Department of Justice, petitioners, v. HON. GUILLERMO G. PURGANAN, Presiding Judge, Regional Trial Court of Manila, Branch 42, and MARK JIMENEZ a.k.a. MARIO BATACAN CRESPO, respondents

[G.R. No. 148571. 17 December 2002.]

${ }^{67}$ Contributed by Harry Roque Jr, Faculty Member, College of Law, University of Philippines, Diliman, Quezon City. 
The Supreme Court denied the respondent Manila Congressman Mark Jimenez's motion that the High Court reconsider its decision nullifying the lower court's grant of bail to him. In this case, Jimenez was subject of an extradition proceeding to the United States for election fraud.

The Supreme Court brushed aside the petitioner's plea that he deserves bail under the exception laid down in its earlier decision, namely, "(1) that, once granted bail, the applicant will not be a flight risk or a danger to the community; and (2) that there exists special, humanitarian and compelling circumstances including, as matter of reciprocity, those cited by the highest court in the requesting state when it grants provisional liberty in extradition cases therein."

It said that there has been no clear and convincing showing as to the absence of flight risk and the non-endangerment of the community, or as to the existence of special, humanitarian and compelling circumstances justifying grant of bail.

The Supreme Court said that the procedure adopted by the Extradition Court of first notifying and hearing a prospective extraditee before the actual issuance of the warrant for his arrest is tantamount to giving notice to flee and avoid extradition. "Whether a candidate for extradition does in fact go into hiding or not is beside the point. In the final analysis, the method adopted by the lower court was completely at loggerheads with the purpose, object and rationale of the law, and overlooked the evils to be remedied," observed the Supreme Court.

The Supreme Court said that contrary to Jimenez's claims, the Extradition Court did not negate the flight risk posed by him; neither did it make a finding on flight risk as it considered the issue irrelevant, having already determined bail to be a matter of right. Without making any finding on flight risk, it found the capacity to flee subservient to "the benefits that respondent may be able to deliver to his constituents" despite the absence from the records of evidence showing the existence of such benefits.

It said that arguments (1) that the Extradition Court exercised due discretion in its grant of bail and (2) that the High Court's "ruling that bail is not a matter of right in extradition cases is contrary to prevailing law and jurisprudence" are neither novel nor deserving of further rebuttal.

It also stressed that the contention that the High Court's decision violates his due process rights is false, because as discussed in an earlier decision, in its simplest concept, due process is merely the opportunity to be heard - which opportunity need not always be a prior one. "In point of fact, private respondent has been given more than enough opportunity to be heard in this Court as well as in the Extradition Court."

The Supreme Court reiterated an earlier suggestion that private respondent can avoid arrest and detention which are the consequences of the extradition proceeding simply by applying for bail before the courts trying the criminal cases against him in the USA. "He himself has repeatedly told us that the indictments against him in the United States are bailable. Furthermore, he is capable, financially and otherwise, of producing the necessary bail in the US. Why then has he not done so? Otherwise stated, Respondent Jimenez has the actual power to lift his arrest and detention arising from his extradition by simply and voluntarily going to and filing bail in the USA." 


\section{Constitutionality of joint RP-US war exercises under the Visiting Forces Agree- ment; interpretation of treaties; municipal v. international law}

ARTHUR D. LIM and PAULINO R. ERSANDO, Petitioners, v. HONORABLE EXECUTIVE SECRETARY as alter ego of HER EXCELLENCY GLORIA MACAPAGAL-ARROYO, and HONORABLE ANGELO REYES in his capacity as Secretary of National Defense, Respondents.

SANLAKAS and PARTIDO NG MANGGAGAWA, Petitioners-Intervenors, v. GLORIA MACAPAGAL-ARROYO, ALBERTO ROMULO, ANGELO REYES, Respondents.

\section{[G.R. No. 151445. April 11, 2002.]}

Beginning January 2002, personnel from the armed forces of the United States of America started arriving in Mindanao to take part, in conjunction with the Philippine military, in "Balikatan 02-1." These so-called "Balikatan" exercises are the largest combined training operations involving Filipino and American troops. In theory, they are a simulation of joint military manœuvres pursuant to the Mutual Defense Treaty, a bilateral defence agreement entered into by the Philippines and the United States in 1951.

The last "Balikatan" was held in 1995. This was due to the paucity of any formal agreement relative to the treatment of United States personnel visiting the Philippines. In the meantime, the respective governments of the two countries agreed to hold joint exercises on a reduced scale. The lack of consensus was eventually cured when the two nations concluded the Visiting Forces Agreement (VFA) in 1999.

The arrival of US troops was seen as part of the international anti-terrorism campaign declared by President George W. Bush in reaction to the tragic events that occurred on 11 September 2001. On that day, three commercial aircraft were hijacked, flown and smashed into the twin towers of the World Trade Center in New York City and the Pentagon building in Washington, D.C. by terrorists with alleged links to al-Qaeda ("the Base"), a Muslim extremist organization headed by the infamous Osama bin Laden. With no comparable historical parallels, these acts caused billions of dollars'-worth of destruction of property and the incalculable loss of hundreds of lives.

One group operating in the Philippines, the Abu Sayyaf terrorist organization, is suspected to have links with Bin Laden's organization. The RP-US exercises were set in Basilan, where the Abu Sayyaf has bases.

The Department of Foreign Affairs and its American counterpart drafted a Terms of Reference (TOR) ${ }^{68}$ document to provide guidelines for the conduct of the ex-

${ }^{68}$ The TOR provides:

1. POLICY LEVEL

1. The Exercise shall be consistent with the Philippine Constitution and all its activities shall be in consonance with the laws of the land and the provisions of the RP-US Visiting Forces Agreement (VFA). 
2. The conduct of this training Exercise is in accordance with pertinent United Nations resolutions against global terrorism as understood by the respective parties.

3. No permanent US basing and support facilities shall be established. Temporary structures such as those for troop billeting, classroom instruction and messing may be set up for use by RP and US Forces during the Exercise.

4. The Exercise shall be implemented jointly by RP and US Exercise Co-Directors under the authority of the Chief of Staff, AFP. In no instance will US Forces operate independently during field training exercises (FTX). AFP and US Unit Commanders will retain command over their respective forces under the overall authority of the Exercise Co-Directors. RP and US participants shall comply with operational instructions of the AFP during the FTX.

5. The exercise shall be conducted and completed within a period of not more than six months, with the projected participation of 660 US personnel and 3,800 RP Forces. The Chief of Staff, AFP shall direct the Exercise Co-Directors to wind up and terminate the Exercise and other activities within the six month Exercise period.

6. The Exercise is a mutual counter-terrorism advising, assisting and training Exercise relative to Philippine efforts against the ASG, and will be conducted on the Island of Basilan. Further advising, assisting and training exercises shall be conducted in Malagutay and the Zamboanga area. Related activities in Cebu will be for support of the Exercise.

7. Only 160 US Forces organized in 12-man Special Forces Teams shall be deployed with AFP field commanders. The US teams shall remain at the Battalion Headquarters and, when approved, Company Tactical headquarters where they can observe and assess the performance of the AFP Forces.

8. US exercise participants shall not engage in combat, without prejudice to their right of self-defense.

9. These terms of Reference are for purposes of this Exercise only and do not create additional legal obligations between the US Government and the Republic of the Philippines.

II. EXERCISE LEVEL

1. TRAINING

a. The Exercise shall involve the conduct of mutual military assisting, advising and training of RP and US Forces with the primary objective of enhancing the operational capabilities of both forces to combat terrorism.

b. At no time shall US Forces operate independently within RP territory.

c. Flight plans of all aircraft involved in the exercise will comply with the local air traffic regulations.

2. ADMINISTRATION \& LOGISTICS

a. RP and US participants shall be given a country and area briefing at the start of the Exercise. This briefing shall acquaint US Forces on the culture and sensitivities of the Filipinos and the provisions of the VFA. The briefing shall also promote the full cooperation on the part of the RP and US participants for the successful conduct of the Exercise.

b. RP and US participating forces may share, in accordance with their respective laws and regulations, in the use of their resources, equipment and other assets. They will use their respective logistics channels.

c. Medical evaluation shall be jointly planned and executed utilizing RP and US assets and resources.

d. Legal liaison officers from each respective party shall be appointed by the Exercise Directors.

3. PUBLIC AFFAIRS

a. Combined RP-US Information Bureaus shall be established at the Exercise Directorate in Zamboanga City and at GHQ, AFP in Camp Aguinaldo, Quezon City.

b. Local media relations will be the concern of the AFP and all public affairs guidelines shall be jointly developed by RP and US Forces.

c. Socio-Economic Assistance Projects shall be planned and executed jointly by RP and US Forces in accordance with their respective laws and regulations, and in consultation with community and 
ercises. On February 1, 2002, petitioners Arthur D. Lim and Paulino P. Ersando filed a petition for certiorari and prohibition, attacking the constitutionality of the joint exercise, arguing in addition that the exercises contravene even the spirit and intent of the VFA. They were joined subsequently by SANLAKAS and PARTIDO NG MANGGAGAWA, both party-list organizations, who filed a petition-in-intervention on February 11, 2002.

The Supreme Court disposed the issue of whether "Balikatan 02-1" is covered by the Visiting Forces Agreement by citing Section 3 of the Vienna Convention on the Law of Treaties, which contains provisions on the interpretation of international agreements. ${ }^{69}$ The Supreme Court noted that the VFA permits United States personnel to engage, on an impermanent basis, in "activities", in the Philippines during war exercises, "the exact meaning of which was left undefined. The High Court said the expression is ambiguous, permitting a wide scope of undertakings subject only to the approval of the Philippine government." But the Supreme Court said that based on the Vienna Convention, the cardinal rule of interpretation must involve an examination of the text, which is presumed to verbalize the parties' intentions. The Convention likewise dictates what may be used as aids, to deduce the meaning of

local government officials.

Contemporaneously, Assistant Secretary for American Affairs Minerva Jean A. Falcon and United States Chargé d'Affaires Robert Fitts signed the Agreed Minutes of the discussion between the Vice-President and Assistant Secretary Kelly.

${ }^{69}$ SECTION 3. - INTERPRETATION OF TREATIES

Article 31

General rule of interpretation

1. A treaty shall be interpreted in good faith in accordance with the ordinary meaning to be given to the terms of the treaty in their context and in the light of its object and purpose.

2. The context for the purpose of the interpretation of a treaty shall comprise, in addition to the text, including its preamble and annexes:

(a) any agreement relating to the treaty which was made between all the parties in connection with the conclusion of the treaty;

(b) any instrument which was made by one or more parties in connection with the conclusion of the treaty and accepted by the other parties as an instrument related to the party.

3. There shall be taken into account, together with the context:

(a) any subsequent agreement between the parties regarding the interpretation of the treaty or the application of its provisions;

(b) any subsequent practice in the application of the treaty which establishes the agreement of the parties regarding its interpretation;

(c) any relevant rules of international law applicable in the relations between the parties.

4. A special meaning shall be given to a term if it is established that the parties so intended.

Article 32

Supplementary means of interpretation

Recourse may be had to supplementary means of interpretation, including the preparatory work of the treaty and the circumstances of its conclusion, in order to confirm the meaning resulting from the application of article 31 , or to determine the meaning when the interpretation according to article 31:

(a) leaves the meaning ambiguous or obscure; or

(b) leads to a result which is manifestly absurd or unreasonable 
terms, to which it refers as the context of the treaty, as well as other elements, may be taken into account alongside the aforesaid context. Hence, a careful reading of the TOR would arrive at the conclusion that it rightly falls within the context of the VFA. It declared:

After studied reflection, it appeared farfetched that the ambiguity surrounding the meaning of the word 'activities' arose from accident. In our view, it was deliberately made that way to give both parties a certain leeway in negotiation ... In this manner, visiting US forces may sojourn in Philippine territory for purposes other than military. As conceived, the joint exercises may include training on new techniques of patrol and surveillance to protect the nation's marine resources, sea search-and-rescue operations to assist vessels in distress, disaster relief operations, civic action projects such as the building of school houses, medical and humanitarian missions, and the like.

It further held:

Under these auspices, the VFA gives legitimacy to the current Balikatan exercises. It is only logical to assume that "Balikatan 02-1," a "mutual antiterrorism advising, assisting and training exercise," falls under the umbrella of sanctioned or allowable activities in the context of the agreement. Both the history and intent of the Mutual Defense Treaty and the VFA support the conclusion that combat-related activities - as opposed to combat itself - such as the one subject of the instant petition, are indeed authorized.

But on the second issue of the constitutionality of allowing US troops on Philippine soil under the new arrangement, the Supreme Court demurred. First, it asked itself, granting that "Balikatan 02-1" is permitted under the terms of the VFA, what may US forces legitimately do in furtherance of their aim to provide advice, assistance and training in the global effort against terrorism?

"Differently phrased, may American troops actually engage in combat in Philippine territory?" "In our considered opinion," said the High Court, "neither the MDT nor the VFA allows foreign troops to engage in an offensive war on Philippine territory."

The Supreme Court observed that the Mutual Defense Treaty and the Visiting Forces Agreement, as in all other treaties and international agreements to which the Philippines is a party, must be read in the context of the 1987 Constitution. In particular, the Mutual Defense Treaty was concluded long before the present Charter, though it nevertheless remains in effect as a valid source of international obligation. It noted that the present Constitution contains key provisions useful in determining the extent to which foreign military troops are allowed in Philippine territory, par- 
ticularly in the Declaration of Principles and State Policies, ${ }^{70}$ and its provisions regulating the foreign relations powers of the Chief Executive when it provides that "[n]o treaty or international agreement shall be valid and effective unless concurred in by at least two-thirds of all the members of the Senate."71 "Even more pointedly," the Supreme Court noted that the Transitory Provisions of the 1987 Charter also state:

Sec. 25. - After the expiration in 1991 of the Agreement between the Republic of the Philippines and the United States of America concerning Military Bases, foreign military bases, troops or facilities shall not be allowed in the Philippines except under a treaty duly concurred in by the Senate and, when the Congress so requires, ratified by a majority of the votes cast by the people in a national referendum held for that purpose, and recognized as a treaty by the other contracting state.

The Philippine Constitution, the High Court had noted, "betrays a marked antipathy towards foreign military presence in the country, or of foreign influence in general. Hence, foreign troops are allowed entry into the Philippines only by way of direct exception. Conflict arises then between the fundamental law and our obligations arising from international agreements.'It had then discussed the relation of international law vis-à-vis municipal law in Philippine jurisprudence - that is, whether the High Court may invalidate a treaty on the ground of unconstitutionality - by citing the case of Philip Morris, Inc. v. Court of Appeals, where the Court held that:

... Withal, the fact that international law has been made part of the law of the land does not by any means imply the primacy of international law over national law in the municipal sphere. Under the doctrine of incorporation as applied in most countries, rules of international law are given a standing equal, not superior, to national legislation.

It also cited the case Ichong $v$. Hernandez, ${ }^{72}$ where the High Court ruled that the provisions of a treaty are always subject to qualification or amendment by a subsequent law, or that it is subject to the police power of the State, and the case of Gonzales v. Hechanova, ${ }^{73}$ where it made the declaration that:

\section{${ }^{70}$ Citing the following provisions in the 1987 Charter:}

SEC. 2. - The Philippines renounces war as an instrument of national policy, adopts the generally accepted principles of international law as part of the law of the land and adheres to the policy of peace, equality, justice, freedom, cooperation, and amity with all nations.

SEC. 7. - The State shall pursue an independent foreign policy. In its relations with other states the paramount consideration shall be national sovereignty, territorial integrity, national interest, and the right to self-determination.

SEC. 8. - The Philippines, consistent with the national interest, adopts and pursues a policy of freedom from nuclear weapons in the country.

71 Sec. 21, Art. VII.

72 G.R. No. L-7995, 101 PHIL 1155 (1957).

${ }^{73}$ G.R. No. L-21897, 9 SCRA 230 (1963). 
... As regards the question whether an international agreement may be invalidated by our courts, suffice it to say that the Constitution of the Philippines has clearly settled it in the affirmative, by providing, in Section 2 of Article VIII thereof, that the Supreme Court may not be deprived "of its jurisdiction to review, revise, reverse, modify, or affirm on appeal, certiorari, or writ of error as the law or the rules of court may provide, final judgments and decrees of inferior courts in -(1) All cases in which the constitutionality or validity of any treaty, law, ordinance, or executive order or regulation is in question." In other words, our Constitution authorizes the nullification of a treaty, not only when it conflicts with the fundamental law, but, also, when it runs counter to an act of Congress.

However, after discussing its own power to nullify treaties which run counter to the fundamental law, the Supreme Court refused to look into the issue of whether American troops are indeed actively engaged in combat alongside Filipino troops under the guise of a war exercises held under the auspices of the VFA and in contravention of the constitutional prohibition. It said such an issue is a question of fact which it is "understandably loath to do."

\section{OTHER RELEVANT STATE PRACTICES}

\section{Opinions of the Secretary of Justice (4 $^{74}$}

Opinion no. 041, s. 2001, 25 July 2001, “The Legal Status of the 1971 Technical Cooperation Agreement Between the Republic of the Philippines and the Federal Republic of Germany"

The National Economic Development Authority (NEDA) sought the opinion of the Department of Justice (DOJ) on the "legal status" of the 1971 Technical Cooperation Agreement between the Republic of the Philippines and the Federal Republic of Germany as to whether it is an executive agreement or a treaty.

For over 30 years now, the Agreement has been invoked by Project Arrangements as a basis for tax exemptions and other privileges for materials and services imported or purchased for German government-assisted projects. Its legal status was questioned when the German government proposed in 1999 some revisions to the 1987 Project Arrangement pertaining to the establishment in Manila of a Project Administrative Service (PAS), a German government agency tasked to support technical cooperation projects in administrative and commercial matters in Manila.

The proposal called for the inclusion of Value Added Tax exemption for materials and services, accommodation and rentals.

The DOJ Secretary held that the document is an executive agreement. Citing the case of Commissioner of Customs v. Eastern Sea Trading ${ }^{75}$ the DOJ Secretary

74 Executive Pronouncements
75 SCRA 351 (1961) 
outlined the distinctions between treaties and executive agreements. In that case the Court had held that:

\begin{abstract}
International agreements involving political issues or changes of national policy and those involving international arrangements of a permanent character usually take the form of treaties. But international agreements embodying adjustments of details carrying out well-established national policies and traditions and those involving arrangements of a more or less temporary nature usually take the form of executive agreements.
\end{abstract}

According to the High Court, treaties are formal documents which require ratification with the approval of two/thirds of the Senate but executive agreements become binding through executive action without the need of a vote by the Senate or by Congress.

It said that the right of the Executive to enter into binding agreements without the necessity of subsequent Congressional approval has been confirmed by long usage. "From the earliest days of our history we have entered into executive agreements covering such subjects as commercial and consular relations, most-favoured-nation rights, patent rights, trademark and copyright protection, postal and navigation arrangements and the settlement of claims," the Court said in the case. "The validity of these has never been seriously questioned by our courts."

Based on the Court's pronouncement, the Justice Secretary said the 1971 Technical Cooperation Agreement is an executive agreement. For one, the Agreement, which aims to intensify the technical and economic development of both parties, does not in any way involve political issues or changes of national policy, according to the DOJ Secretary. "On the contrary, the Agreement, as well as its revisions in 1987 and, as proposed, in 1999, provides for details in carrying out the purpose of supporting development cooperation between the two (2) countries." Also, the 1971 Technical Cooperation Agreement and the consequent Arrangements provide for a definite period within which they shall remain in force. "Thus, said agreements/arrangements are not of a permanent character but only temporary in nature."

Nevertheless, the DOJ secretary said the fact that the 1971 Technical Cooperation Agreement embodies provisions on tax exemptions which ordinarily should be found in a treaty does not necessarily detract from its nature as an executive agreement on the assumption that the tax exemptions granted therein are based on provisions of existing laws and that the Agreement only seeks to effectuate or implement these provisions insofar as they may apply to the situations contemplated in the Agreement.

\title{
NATIONAL LAWS ON INTERNATIONAL LAW MATTERS
}

\section{Republic Act No. 9168 "Philippine Plant Variety Protection Act."}

Signed into law by the President of the Philippines on 7 June 2002, the Philippine Plant Variety Protection Act (PVPA) of 2002 intends to provide protection to new 
plant varieties by establishing a plant variety protection (PVP) system, an administrative procedure with which an applicant must comply to secure a form of intellectual property right called the "plant breeder's right".

The new Law essentially conforms to the 1991 UPOV Convention ${ }^{76}$ (the French acronym for the Union for the Protection of New Plant Varieties) with respect to the granting of plant breeder's rights. It also creates the National Plant Variety Protection Board, mandated to promulgate guidelines for the effective implementation of the Law, and having original jurisdiction over petitions for compulsory licensing, nullification and cancellation of Certificates of Plant Variety Protection.

To support national genetic conservation activities, the Law further establishes a Gene Trust Fund for the benefit of organizations or institutions managing and operating an accredited gene bank. It also encourages farming communities and organizations to build an inventory of locally bred varieties.

The PVPA provides that the certificate of Plant Variety Protection shall be granted to varieties that are: a) new, b) distinct, c) uniform, and d) stable.

The Law provides that a variety shall be deemed new if the propagating or harvested material of the variety has not been sold, offered for sale or otherwise disposed of to others, by or with the consent of the breeder, for purposes of exploitation of the variety:

(a) In the Philippines for more than one year before the date of filing of an application for plant variety protection; or

(b) In other countries or territories in which the application has been filed, for more than four years or, in the case of vines or tress, more than six years before the date of filing of an application for Plant Variety Protection.

However, the requirement of novelty provided for in the law does not apply to varieties sold, offered for sale or disposed of to others for a period of five years before the approval of the law, provided that application for PVP is filed within one year from the approval of the law.

Under the law, a variety shall be deemed distinct if it is clearly distinguishable from any commonly known variety. Moreover, the filing of an application for the granting of a plant variety protection or for the entering of a new variety into an official register of variety in the Philippines or in any country, makes the said variety a matter of public knowledge from the date of the filing of the application, as long as the application leads to the granting of a Certificate of Plant Variety Protection

\footnotetext{
76 Entered into force 24 April 1998. The original UPOV convention was created in 1961 and provided for protection of plant varieties and created "breeders rights." The 1991 convention enlarges the monopoly privileges of "breeders." Under the 1991 Convention, UPOV member states are required to give plant breeders a right over "all production of seed or other planting material". UPOV is a part of the international conventions and treaties under the the World Intellectual Property Organization (WIPO).UPOV 1991 was negotiated at a diplomatic conference under WIPO auspices in Geneva.
} 
or the entering of the said other variety into the official register of variety, as the case may be.

The Law deems a variety uniform "if, subject to the variation that may be expected from the particular features of its propagation, it is sufficiently uniform in its relevant characteristics."

The Law deems a variety stable "if its relevant characteristics remain unchanged after repeated propagation or, in the case of a particular cycle of propagation, at the end of each such cycle." These are called the DUSN criteria, set forth by UPOV.

Under the PVP system put in place by the new Law, a plant breeder could apply for a PVP certificate over a new plant variety from the board.

A certificate and all attendant ownership rights would be given to the plant breeder if the plant variety has passed the test of distinctness, uniformity, stability, and newness.

Holders of a certificate of plant variety would have the right to authorize the production or reproduction, conditioning for the purpose of propagation, offering for sale, selling or other marketing strategies, exporting, importing and stocking of the plant variety.

However, any person who believes that the applicant is not entitled to the grant of the Certificate of Plant Variety Protection may file an opposition thereto within the period prescribed by the Board from the date of its publication and before the issuance of the Certificate of Plant Variety Protection. Opposition to the application may be made on the following grounds:

(a) that the person opposing the application is entitled to the breeder's right as against the applicant;

(b) that the variety cannot be registered under the law.

If the opposition is based on the conditions of Plant Variety Protection, such opposition shall be considered together with the examination of the application.

A holder of a certificate also has rights over:

(a) Varieties which are essentially derived from the protected variety, where the protected variety is not itself an essentially derived variety;

(b) Varieties which are not clearly distinct from the protected variety; and

(c) Varieties whose production requires the repeated use of the protected variety.

The law considers a variety as essentially derived from the initial variety when:

(a) It is predominantly derived from the initial variety, or from a variety that is itself predominantly derived from the initial variety, while retaining the expression of the essential characteristics that result from the genotype or combination of genotypes of the initial variety;

(b) It is clearly distinguishable from the initial variety; 
(c) Except for the differences which result from the act of derivation, it conforms to the initial variety in the expression of the essential characteristics that result from the genotype or combination of genotypes of the initial variety.

A provision on exemption to plant variety protection acknowledges the traditional right of the farmer to save, use, replant and sell his produce from a protected variety, provided that propagation is not being done for commercial purposes.

The law defines a "breeder" as one who "discovered ... a new plant variety". Specifically, a "breeder" may be:

1) The person who bred, or discovered and developed a new plant variety; or

2) The person who is the employer of the aforementioned person or who has commissioned the work; or

3) The successors-in-interest of the foregoing persons as the case may be; or

4) The holder of the Certificate of Plant Variety Protection.

The law penalizes infringement of a Certificate of Plant Variety Protection. An infringer is defined in the law as any person who, without being entitled to do so, performs the following acts:

(a) Sell the novel variety, or offer it or expose it for sale, deliver it, ship it, consign it, exchange it, or solicit an offer to buy it, or any other transfer of title or possession of it; or

(b) Import the novel variety into, or export it from, the Philippines; or

(c) Sexually multiply the novel variety as a step in marketing (for growing purposes) the variety; or

(d) Use the novel variety in producing (as distinguished from developing) a hybrid or different variety therefrom; or

(e) Use seed which had been marked "unauthorized propagation prohibited" or "unauthorized seed multiplication prohibited" or progeny thereof to propagate the novel variety; or

(f) Dispense the novel variety to another, in a form which can be propagated, without notice as to being a protected variety under which it was received;

(g) Fails to use a variety denomination the use of which is obligatory under Section 15 ; or

(h) Perform any of the foregoing acts even in instances in which the novel variety is multiplied other than sexually, except in pursuance of a valid Philippine plant patent; or

(i) Instigate or actively induce performance of any foregoing acts, may be sued by the holder, who may also avail of all such relief as are available in any proceeding involving infringements of other proprietary rights.

Under the law, any person who violates any of the rights of the holder may also suffer the penalty of imprisonment of not less than three years but not more than six years and/or a fine of up to three times the profit derived by virtue of the infringe- 
ment but which in no case should be less than one hundred thousand pesos (P100,000.00).

\section{Republic Act No. 9160 "An Act Defining the Crime of Money Laundering, Providing Penalties Therefor and for other Purposes"}

The new law on anti-money laundering was passed on 29 September $2001 .^{77}$ It sets out as the Philippine government's declared policy "to protect and preserve the integrity and confidentiality of bank accounts and to ensure that the Philippines shall not be used as a money laundering site for the proceeds of any unlawful activity. Consistent with its foreign policy, the State shall extend cooperation in transnational investigations and prosecutions of persons involved in money laundering activities whenever committed."

Sec. 4 of the law defines money laundering as "a crime whereby the proceeds of an unlawful activity are transacted, thereby making them appear to have originated from legitimate sources."

Under the law, money laundering is committed by the following:

(a) Any person knowing that any monetary instrument or property represents, involves, or relates to the proceeds of any unlawful activity, transacts or attempts to transact said monetary instrument or property.

(b) Any person knowing that any monetary instrument or property involves the proceeds of any unlawful activity performs or fails to perform any act as a result

77 The Paris-based Financial Action Task Force (FATF), established by the world's industrialized countries in 1989, labelled the Philippines a 'non-cooperative country' in global efforts to combat money laundering in June 2000. The Philippines has a Bank Secrecy Law, which virtually guarantees the complete privacy of the depositor. Banks are not required to make a careful check on the identity of the individual opening the account, nor are they under any obligation to report any suspicious financial transactions. Moreover, FCDUs (Foreign Currency Deposit Unit) were completely protected by another law.

The FATF action compelled the Philippine Central Bank to take initial actions against money laundering. Circular No. 251, dated 7 July 2000, outlined the framework of countermeasures. This was followed by many circulars issued in an attempt to strengthen the provisions but their failure to address the issue was only highlighted by the the impeachment proceedings held against former President Estrada who was himself accused of using false name accounts to launder money from illegal gambling. In June, 2001, the FATF once again included the Philippines on its list, warning that if the Philippines did not legislate money laundering countermeasures by the end of September, financial sanctions would be imposed.

The FATF laid down five minimum conditions for inclusion in the new law: (1) the criminalization of money laundering, (2) the establishment of a system for the reporting of suspicious transactions, (3) obligatory confirmation of the customer's identity (when opening a new account), (4) the elimination of excessive bank secrecy, and (5) international cooperation. Threatened with economic sanctions, the Philippines' legislature rushed to pass a law on anti-money laundering just a day before the 30 September 2001 deadline set by the international body. 
of which he facilitates the offence of money laundering referred to in paragraph (a) above.

(c) Any person knowing that any monetary instrument or property is required under this Act to be disclosed and filed with the Anti-Money Laundering Council (AMLC), fails to do so.

The new law covers transactions by:

(1) banks, non-banks, quasi-banks, trust entities, and all other institutions and their subsidiaries and affiliates supervised or regulated by the Bangko Sentral ng Pilipinas (BSP);

(2) Insurance companies and all other institutions supervised or regulated by the Insurance Commission; and

(3) (i) securities dealers, brokers, salesmen, investment houses and other similar entities managing securities or rendering services as investment agent, advisor, or consultant, (ii) mutual funds, close and investment companies, common trust funds, pre-need companies and other similar entities, (iii) foreign exchange corporations, money changers, money payment, remittance, and transfer companies and other similar entities, and (iv) "other entities administering or otherwise dealing in currency, commodities or financial derivatives based thereon, valuable objects, cash substitutes and other similar monetary instruments or property supervised or regulated by Securities and Exchange Commission."

Under the new law, a covered transaction is any "single, series, or combination of transactions involving a total amount in excess of four million pesos $(\mathrm{P} 4,000,000)$ or an equivalent amount in foreign currency based on the prevailing exchange rate within five (5) consecutive banking days except those between a covered institution and a person who, at the time of the transaction was a properly identified client and the amount is commensurate with the business or financial capacity of the client; or those with an underlying legal or trade obligation, purpose, origin or economic justification."

It likewise refers to a single, series or combination or pattern of unusually large and complex transactions in excess of four million pesos $(\mathrm{P} 4,000,000)$ especially cash deposits and investments having no credible purpose or origin, underlying trade obligation or contract. However, those deposits made before the law took effect are not covered by the law.

The new law 'criminalizes' money laundering by penalizing those who obtain funds through kidnapping, smuggling, drug-trafficking, illegal gambling, hijacking, graft, plunder, extortion, piracy, theft, swindling, E-commerce violations, arson and murder and securities fraud and "felonies of similar nature under the penal codes of other countries." Violators face a maximum penalty of 14 years in prison and a fine of three million pesos.

Under the new law, other than money laundering related to 14 types of illegal activity, the failure to keep the required records, submission of false reports and leaking of confidential information are all liable to punishment by fines or imprison- 
ment. Unauthorized public disclosures of AMLA proceedings are punishable by a maximum of four years in prison and five hundred thousand pesos (P500,000) in fines.

The law also made the opening of anonymous accounts or accounts with fictitious names illegal, although peso and foreign currency non-checking numbered accounts are allowed. A separate section details requirements imposed on banks, quasi-banks and other financial institutions covered by the law for record-keeping - for five years - reporting and client identification as a means of preventing money laundering. Covered institutions are now required by law to report to the AMLC all covered transactions within five working days from the date the transactions were made, unless the Supervising Authority concerned prescribes a longer period not exceeding ten working days.

The law established an Anti-Money Laundering Council (AMLC), composed of the BSP governor and the chief commissioner of the Security Exchange Commission and the head of the Insurance Commission as members. The AMLC is responsible for the execution of anti-money laundering countermeasures and is authorized to freeze deposit accounts that it deems likely to be connected to illegal activity, for up to 15 days. No court may un-freeze the accounts, except the Supreme Court and the Court of Appeals. The Council can even act at the behest of foreign governments. It may also institute forfeiture proceedings against laundered money.

The law also created an oversight committee composed of seven senators and seven congressmen supposedly to safeguard confidentiality and guard against harassment particularly during an election period, when candidates have deep pockets let alone substantial accounts. ${ }^{78}$

\section{Republic Act 9147 "An Act Providing for the Conservation and Protection of Wildlife Resources and Their Habitats, Appropriating Funds Therefor and For Other Purposes"}

Signed into law on 30 July 2001, the Wildlife Resources Conservation and Protection Act expressly acknowledges Philippine commitments to international conventions on the protection of wildlife and their habitats.

The new law covers all wildlife species found in all areas of the country, including protected areas under Republic Act No. 7586, otherwise known as the National Integrated Protected Areas System (NIPAS) Act, and critical habitats. It also applies to exotic species which are subject to trade, are cultured, maintained and/or bred in captivity or propagated in the country.

\footnotetext{
78 The new law failed to get the full agreement of the FATF, principally because of what the international body views as a serious inadequacy: it covers only accounts of more than four million pesos, a threshold figure much too high than the FATF-recommended figure of P500,000. Also, the new law still requires the order of a competent court before deposit accounts suspected of having connections to money laundering may be investigated.
} 
The new law aims to protect the country's fauna from illicit trade, abuse and destruction, through (1) conserving and protecting wildlife species and their habitats, (2) regulating the collection and trade of wildlife, (3) pursuing, with due regard to the national interest, the Philippine commitment to international conventions, protection of wildlife and their habitats, and (4) initiating or supporting scientific studies on the conservation of biological diversity.

Under the law, all designated critical habitats shall be protected, in coordination with the local government units and other concerned groups, from any form of exploitation or destruction which may be detrimental to the survival of species dependent upon these areas.

The law allocates jurisdiction to the Department of Environment and Natural Resources (DENR) over all terrestrial plant and animal species, all turtles and tortoises and wetland species, including but not limited to crocodiles, waterbirds and all amphibians and dugong. Meanwhile, the Department of Agriculture (DA) has jurisdiction over all declared aquatic critical habitats, all aquatic resources including but not limited to all fishes, aquatic plants, invertebrates and all marine mammals, except dugong. The secretaries of the DENR and the DA shall review, and by joint administrative order, revise and regularly update the list of species under their respective jurisdiction. In the Province of Palawan, jurisdiction is given to the Palawan Council for Sustainable Development pursuant to Republic Act No. 7611.

Under the law, the DENR issues wildlife farm culture permits for the breeding or propagation of wildlife for commercial purposes, subject to the condition that only progenies of wildlife raised, as well as unproductive parent stock, shall be utilized for trade and that commercial breeding operations for wildlife, whenever appropriate, shall be subject to an environmental impact study.

The DENR Secretary is mandated by law to establish, within one (1) year after it takes effect, to establish a list of economically-important species. A population assessment of such species shall be conducted within a reasonable period and shall be regularly reviewed and updated by the Secretary.

The DENR Secretary will allow the collection of certain species only when the results of official assessments show that, despite certain extent of collection, the population of such species can still remain viable and capable of recovering its numbers. For this purpose, the Secretary shall establish a schedule and volume of allowable harvests.

And whenever an economically important species become threatened, any form of collection shall be prohibited except for scientific, educational or breeding/propagation purposes. The law provides that introduction, reintroduction or re-stocking of endemic and indigenous wildlife shall be allowed only for population enhancement or recovery. Any introduction shall be subject to a scientific study. The introduction of exotic species into protected areas and critical habitats is prohibited. If and when introduction is allowed, it shall be subjected to environmental impact assessment and the informed consent from local stakeholders.

Under the law, conservation, breeding or propagation of threatened species shall be encouraged to enhance its population in its natural habitat. Breeding shall be done simultaneously with the rehabilitation and protection of the habitat where the captive- 
bred or propagated species shall be released or reintroduced. When economically important species become threatened, collection shall be limited to scientific, educational or breeding purposes.

The law penalizes the following acts:

a. killing and destroying wildlife species, except when it is done as part of the religious rituals of established tribal groups or indigenous cultural communities, when the wildlife is afflicted with an incurable communicable disease, when it is deemed necessary to put an end to the misery suffered by the wildlife, or when it is done to prevent an imminent danger to the life or limb of a human being; when the wildlife is killed or destroyed after it has been used in authorized research or experiments

b. inflicting injury which cripples and/or impairs the reproductive system of wildlife species

c. effecting any of the following acts in critical habitats: dumping of waste products detrimental to wildlife; squatting or otherwise occupying any portion of the critical habitat; mineral exploration and/or extraction; burning; logging; and quarrying

d. the introduction, reintroduction, or restocking of wildlife resources.

e. the trading of wildlife.

f. collecting, hunting or possessing wildlife, their by-products and derivatives

g. gathering or destroying of active nests, nest trees, host plants and the like

h. maltreating and/or inflicting other injuries not covered by the preceding paragraph; and

i. the transporting of wildlife.

The law imposes stiff penalties and fines: a maximum of 12 years in prison and a fine of one million pesos is imposed, if harm is inflicted or undertaken against species listed as critical.

The fines collected will go into a Management Fund, along with damages awarded, fees, charges, donations, endowments, administrative fees or grants. The fund is administered by DENR as a special account in the National Treasury. It will be primarily earmarked for the rehabilitation or restoration of habitats. The Fund will also support scientific research, enforcement and monitoring activities, as well as enhancement of capabilities of relevant agencies.

\section{Signed into law on 8 June 2001, RA 9139, otherwise known as the Administrative Naturalization Act of 2000, lays down administrative procedures for granting citizenship to aliens.}

Under the law, an alien must meet the following requirements to qualify as an applicant for naturalization through administrative proceedings:

(a) The applicant must be born in the Philippines and have been a resident since birth; 
(b) The applicant must be not less than eighteen (18) years of age, at the time of filing of his/her petition;

(c) The applicant must be of good moral character and believe in the underlying principles of the Philippine Constitution, and must have conducted himself/herself in a proper and irreproachable manner during his/her entire period of residence in the Philippines in his/her relation with the duly constituted government as well as with the community in which he/she is living;

(d) The applicant must have received his/her primary and secondary education in any public school or private educational institution duly recognized by the Department of Education, Culture and Sports, where Philippine history, government and civics are taught and prescribed as part of the school curriculum and where enrollment is not limited to any race or nationality: Provided, That should he/she have minor children of school age, he/she must have enrolled them in similar schools;

(e) The applicant must have a known trade, business, profession or lawful occupation, from which he/she derives income sufficient for his/her support and if he/she is married and/or has dependants, also that of his/her family: Provided, however, That this shall not apply to applicants who are college degree holders but are unable to practise their profession because they are disqualified to do so by reason of their citizenship;

(f) The applicant must be able to read, write and speak Filipino or any of the dialects of the Philippines; and

(g) The applicant must have mingled with the Filipinos and evinced a sincere desire to learn and embrace the customs, traditions and ideals of the Filipino people.

However, the following are not qualified to be naturalized as Filipino citizens:

(a) Those opposed to organized government or affiliated with any association of group of persons who uphold and teach doctrines opposing all organized governments;

(b) Those defending or teaching the necessity of or propriety of violence, personal assault or assassination for the success or predominance of their ideas;

(c) Polygamists or believers in the practice of polygamy;

(d) Those convicted of crimes involving moral turpitude;

(e) Those suffering from mental alienation or incurable contagious diseases;

(f) Those who, during the period of their residence in the Philippines, have not mingled socially with Filipinos, or who have not evinced a sincere desire to learn and embrace the customs, traditions and ideals of the Filipinos;

(g) Citizens or subjects with whom the Philippines is at war, during the period of such war; and

(h) Citizens or subjects of a foreign country whose laws do not grant Filipinos the right to be naturalized citizens or subjects.

Petitions for citizenship under this law are filed with the Special Committee on Naturalization, which is composed of the Solicitor General as chairman, the Secretary 
of Foreign Affairs, or his representative, and the National Security Adviser, as members, with the power to approve, deny or reject applications for naturalization. A forty thousand peso (P40,000) filing fee is charged from each applicant. If the petition is approved the Committee charges the applicant a naturalization fee of one hundred thousand pesos (P100,000) payable as follows: fifty thousand pesos (P50,000) upon the approval of the petition and fifty thousand pesos $(\mathrm{P} 50,000)$ upon the taking of the oath of allegiance to the Republic of the Philippines; forthwith, a certificate of naturalization shall be issued. Within sixty days from the issuance of the certificate, the petitioner shall take an oath of allegiance in the proper forum upon proof of payment of the required naturalization processing fee and certificate of naturalization. Should the applicant fail to take the abovementioned oath of allegiance within the said period of time, the approval of the petition shall be deemed abandoned.

Applicants under the law shall file with the Special Committee on Naturalization created under Section 6 hereof, a petition of five copies legibly typed and signed, thumb-marked and verified by him/her, with the latter's passport-sized photograph attached to each copy of the petition, and setting forth the following:

(a) The petitioner's name and surname, and any other name he/she has used or by which he/she is known;

(b) The petitioner's present and former places of residence;

(c) The petitioner's place and date of birth, the names and citizenship of his/her parents and their residences;

(d) The petitioner's trade, business, profession or occupation, and if married, also that of his/her spouse;

(e) Whether the petitioner is single or married or his/her marriage is annulled. If married, petitioner shall state the date and place of his/her marriage, and the name, date of birth, birthplace, citizenship and residence of his/her spouse; and if his marriage is annulled, the date of decree of annulment of marriage and the court which granted the same;

(f) If the petitioner has children, the name, date and birthplace and residences of his/her children;

(g) A declaration that the petitioner possesses all the qualifications and none of the disqualifications under this Act;

(h) A declaration that the petitioner shall never be a public charge; and

(i) A declaration that it is the petitioner's true and honest intention to acquire Philippine citizenship and to renounce absolutely and forever any prince, potentate, State or sovereign, and particularly the country of which the applicant is a citizen or subject.

(2) The application shall be accompanied by:

(a) Duplicate original or certified photocopies of the petitioner's birth certificate;

(b) Duplicate original or certified photocopies of the petitioner's alien certificate of registration and native born certificate of residence;

(c) Duplicate original or certified photocopies of the petitioner's marriage certified, if married, or the death certificate of his spouse, if widowed, or the court decree annulling his marriage, if such was the fact; 
(d) Duplicate original or certified photocopies of birth certificates, alien certificate of registration or native born certificate of residence if any, of the petitioner's minor children, wherever applicable;

(e) An affidavit of financial capacity by the petitioner, and sworn statements on the good moral character of the petitioner by at least two (2) Filipino citizens of good reputation in his/her place of residence stating that they have personally known the petitioner for at least a period of ten (10) years and that the said petitioner has in their own opinion all the qualifications necessary to become a citizen of the Philippines and is not in any way disqualified under the provisions of this Act;

(f) A medical certificate that petitioner is not a user of prohibited drugs or otherwise drug dependent and that he/she is not afflicted with acquired immune deficiency syndrome (AIDS);

(g) School diploma and transcript of records of the petitioner in the schools he/she attended in the Philippines. Should the petitioner have minor children, a certification that his children are enrolled in a school where Philippine history, government and civics are taught and are part of the curriculum; and

(h) If gainfully employed, the income tax returns for the past three years.

Within fifteen days from the receipt of the petition, the Committee shall determine whether the petition is complete in substance and in form. If such petition is complete, the Committee shall immediately publish pertinent portions of the petition, indicating the name, qualifications and other personal circumstances of the applicant, once a week for three consecutive weeks in a newspaper of general circulation, and have copies of the petition posted in any public or conspicuous area.

The Committee shall immediately furnish the Department of Foreign Affairs (DFA), the Bureau of Immigration (BI), the civil registrar of the petitioner's place of residence and tile National Bureau of Investigation (NBI) copies of the petition and its supporting documents. These agencies shall have copies of the petition posted in any public or conspicuous area in their buildings, offices and premises, and shall, within thirty days from the receipt of the petition, submit to the Committee a report stating whether or not the petitioner has any derogatory record on file or any such relevant and material information which might be adverse to the petitioner's application for citizenship.

If the petition is found by the Committee to be wanting in substance and form, the petition shall be dismissed without prejudice. The Committee is mandated by law to act on the petition within a sixty-day period.

Once the applicant's petition is approved, his alien wife and minor children may then file a petition for cancellation of their alien certificates of registration with the Committee subject to the payment of the filing fee of twenty thousand pesos $(\mathrm{P} 20,000)$ and naturalization fee of forty thousand pesos $(\mathrm{P} 40,000)$ payable as follows: twenty thousand pesos (P20,000) upon the approval of the petition and twenty thousand pesos (P20,000) upon the taking of the oath of allegiance to the Republic of the Philippines. 
If the applicant is a married woman, the approval of her petition for administrative naturalization will not benefit her alien husband; however, her minor children may file a petition for cancellation of their alien certificates of registration with the Bureau of Immigration, subject to the requirements of existing laws.

The Special Committee may cancel certificates of naturalization issued under this Act in the following cases:

(a) If it finds that the naturalized person or his/her duly authorized representative made any false statement or misrepresentation or committed any violation of law, rules and regulations in connection with the petition for naturalization, or if he/she otherwise obtains Philippine citizenship fraudulently or illegally, the certificate of naturalization shall be cancelled;

(b) If the naturalized person or his wife, or any of his minor children who acquire Filipino citizenship by virtue of his naturalization shall, within five years next following the grant of Philippine citizenship, establish permanent residence in a foreign country, that individual's certificate of naturalization or acquired citizenship shall be cancelled or revoked: Provided, That the fact of such person's remaining for more than one year in his country of origin, or two years in any foreign country, shall be considered prima facie evidence of intent permanently to reside therein;

(c) If the naturalized person or his wife or child with acquired citizenship allows himself or herself to be used as a dummy in violation of any constitutional or legal provision requiring Philippine citizenship as a condition for the exercise, use or enjoyment of a right, franchise or privilege, the certificate of naturalization or acquired citizenship shall be cancelled or revoked; and

(d) If the naturalized person or his wife or child with acquired citizenship commits any act inimical to national security, the certificate of naturalization or acquired citizenship shall be cancelled or revoked.

In case the naturalized person holds any hereditary title, or belongs to any order of nobility, he shall make an express renunciation of his title or membership in this order of nobility before the Special Committee or its duly authorized representative, and such renunciation shall be included in the records of his application for citizenship. 


\section{OTHER RELEVANT STATE PRACTICE}

\section{The RP-PRC Extradition Treaty and the RP-Hong Kong Mutual Legal Assist- ance Pact}

The Philippines signed a new extradition treaty with the People's Republic of China. ${ }^{79}$ The treaty, under Article 2, para. 1, contains the double criminality principle, a well-established principle of international law that requires that for an offence to be extraditable, it must be "punishable under the laws of both parties." The article carries a list of the crimes for which a person can be extradited.

However, Article 4 of the treaty acknowledges the political offence exception, which prevents a state from using extradition as a weapon to bring back political rebels and dissenters within its coercive power.

The treaty also has a Rule of Specialty. Under Article 16, when the Philippine authorities extradite a person to China for a specified offence, that person can be tried by China only for that offence, and for no other. The rule ensures that the requesting state does not defeat the "political offence exception": it requests extradition for a common crime, then amends the accusation and charges the extraditee for another offence.

Also, the treaty provides for the non-extradition of a party's own nationals under Article 3, para. 1 . The treaty moreover has a surrender provision obligating the two parties to arrest and surrender fugitives from the requesting state.

\section{The RP-HONG KONG Agreement on Mutual Assistance on Legal and Criminal Matters}

While the RP-China Treaty pertains to extradition alone, the RP-HK Agreement ${ }^{80}$ covers to a wider range of judicial cooperation - serving of documents, obtaining evidence, searches and seizures, effecting testimony of witnesses. However, it excludes extradition, and allows cooperation between the two countries to the task of "identifying and locating persons" and "effecting the temporary transfer of persons in custody to appear as witnesses."

The agreement, however, carries the same safeguards found in the RP-China Extradition Treaty: the political offence exception (Article IV, Limitations on Compliance, para. 1.b, 1.c, and 1.d), and the double criminality requirement (id., para. 1.g).

The Agreement also expressly designates the Department of Justice as the executing authority in the Philippines - a feature that is only assumed in the RP-China Extradition Treaty.

\footnotetext{
79 Signed by the two parties on 23 February 2001. The Agreement complements a memorandum of agreement signed by the two parties on 30 October 2001 on cooperation against illicit traffic and abuse of narcotic drugs, psychotropic substances and control of precursor chemicals.
} 
Negotiated by both parties as early as 1998, the agreement allows the two governments to cooperate and provide mutual assistance in the investigation and prosecution of criminal offenses and in proceedings related to criminal matters.

Under the agreement, the governments pledge to help each other in identifying and locating persons, serving documents, obtaining evidence, articles or documents, executing requests for search and seizure, and facilitating the appearance of witnesses. The agreement also enables the two parties to effect the temporary transfer of persons in custody to appear as witnesses; to obtain judicial or official records; to trace, restrain, forfeit and confiscate the proceeds and instruments of criminal activities; to recover pecuniary penalties for offenses, and to provide information, documents and records, as well as to deliver property.

\author{
SRI LANKA ${ }^{81}$
}

JUDICIAL DECISIONS

Fundamental Rights - Provincial Council elections - unlawful poll at 23 polling stations - failure to declare the poll void and to appoint a re-poll - Articles 12(1) and 14(1) of the Constitution

\title{
MEDIWAKE AND OTHERS v. DAYANANDA DISSANAYAKE, COMMISSIONER OF ELECTIONS AND OTHERS \\ [(2001) 1 SRI LANKA LAW REPORTS PAGE 177, SUPREME COURT, FERNANDO J, WADUGODAPITIYA J AND ISMAIL J]
}

The four petitioners were registered voters of the Kandy District, one of the three districts in the Central Province. They were members of a particular political party; the first petitioner was a candidate for the Kandy District and the fourth petitioner was a polling agent.

Provincial Council elections in the Province took place on 6 April 1999 under the Provincial Council Elections Act. The petitioners alleged that on the day of the elections at 25 named polling stations in the District various incidents took place which affected the validity of the election results. They pleaded that the failure of the first and second respondents to conduct a proper poll at these polling stations and the failure of the first respondent to declare the poll at those stations void and order a re-poll violated their fundamental rights under the Constitution. The Court granted them leave to proceed in respect of the alleged infringement to Articles 12(1) and 14(1)(a) of the Constitution. These Articles read as follows.

${ }^{81}$ Contributed by Camena Guneratne, Senior Lecturer, Department of Legal Studies, Open University of Sri Lanka. 
Article 12 (1) - All persons are equal before the law and are entitled to the equal protection of the law.

Article 14 (1) (a) - Every citizen is entitled to the freedom of speech and expression including publication.

On the facts of the case, the Court concluded that incidents of ballot stuffing, harassment and chasing away of polling agents of a particular political party had taken place. The Court considered the impact of these incidents on the fundamental rights of the petitioners.

The Court held that the petitioners, being registered voters of the Kandy District, had a legal right to vote in that election. In an earlier case it had been held that voting, in the exercise of that legal right, was a form of "expression" guaranteed by Article 14 (1) (a). ${ }^{82}$ The Court further held that the requirement that elections must be free, equal and by secret ballot is fundamental to any election in any nation which respects the sovereignty of the people, representative democracy and the rule of law. The Court therefore took the view that "the right to a free, equal and secret ballot is an integral part of the citizen's freedom of expression when he exercises that freedom through his right ... to vote".

However, although it was clear that many voters had been unable to exercise their right to a free, equal and secret ballot, none of the petitioners claimed that they themselves had been prevented from voting. Therefore, while the irregularities complained of directly infringed the right of others to vote, the question arose as to whether this alone constituted an infringement of the petitioners' rights under Article 12(1) and 14(1)(a).

The Court stated that in order to decide that question it was necessary to consider the true nature of a citizen's right to vote, and Article 25 of the International Covenant on Civil and Political Rights was a useful starting point. Article 25 was quoted as follows:

Every citizen shall have the right and the opportunity without any of the distinctions mentioned in Article 2 and without unreasonable restrictions:

(a) To take part in the conduct of public affairs, directly or through freely chosen representatives;

(b) To vote and to be elected at genuine periodic elections, which shall be by universal and equal suffrage and shall be held by secret ballot, guaranteeing the free expression of the will of the electors...

The Court went on to hold: ${ }^{83}$

Sri Lanka is a party to that Covenant and its sister Covenant, which together constitute the international Bill of Human Rights. It would be idle to argue that our election laws pertaining to Provincial Council elections are not founded on guarantees to every

82 Karunatilleke v. Dissanayake (1999) 1 Sri Lanka Law Reports, page 157.

83 (2001) Sri Lanka Law Reports, at page 211. 
citizen of the right to "take part" in public affairs, through representatives freely chosen by him, at a genuine election, by universal and equal suffrage, held by secret ballot, ensuring the free expression of the will of the electorate. Article 27 (15) [of the Constitution] requires the State "to endeavour to foster respect for international law and treaty obligations in dealings among nations." Accordingly, in interpreting the relevant provisions of an enactment regulating any election a Court must, unless there is compelling language, favour a construction which is consistent with the international obligations of the State, especially those imposed by the international Bill of Human Rights. I hold that those guarantees are an essential part of the freedom of expression recognised by Article 14(1)(a).

The citizen's right to vote includes the right to freely choose his representative, through a genuine election which guarantee the free expression of the will of the electors; not just his own. Therefore, not only is a citizen entitled himself to vote at a free, equal and secret poll, but he also has a right to a genuine election guaranteeing the free expression of the will of the entire electorate to which he belongs. Thus if a citizen desires that candidate $X$ should be his representative and if he is allowed to vote for $\mathrm{X}$ but other like-minded citizens are prevented from voting for $\mathrm{X}$, then his right to the free expression of the will of the elector has been denied. If $51 \%$ of the electors wish to vote for X, but ten per cent are prevented from voting - in consequence of which $\mathrm{X}$ is defeated - that is a denial of the rights not only of the ten per cent but of the $41 \%$ as well. Indeed, in such a situation, the $41 \%$ may legitimately complain that they might as well not have voted. To that extent, the freedom of expression of like-minded voters when exercised through the electoral process is a collective one, although they may not be members of any group or association.

A citizen's freedom of speech guaranteed by article 14(1)(a) is violated not only when he is not permitted to speak, but even when others are prevented from listening to him. A corollary of A's freedom of speech is A's right that those to whom he wishes to speak should be permitted to listen to him - provided of course that they want to listen to him. If a part of his audience is driven away, the effectiveness of the exercise of his freedom of speech is impaired, and thereby his right is infringed.

\section{NATIONAL LAWS ON INTERNATIONAL LAW MATTERS}

\section{Civil Aspects of International Child Abduction Act No. 10 of 2001}

This Act was passed to give effect to The Hague Convention on Civil Aspects of International Child Abduction adopted at The Hague on 25 October 1980. The Preamble to the Act refers to the Convention and states that as Sri Lanka has acceded to the Act it is necessary to make legal provision to enable Sri Lanka to fulfil its obligations under it.

The Act comes into operation on such date as the Minister certifies as the date on which the Convention enters into force in respect of Sri Lanka. The Minister may 
also specify the countries in respect of which the provisions of the Act shall apply and the date on which such provisions will start coming into force. These countries are known as specified countries.

The Act defines what is meant by the wrongful removal from or retention in Sri Lanka of a child. It designates the Secretary to the Ministry of Justice as the Central Authority for the purposes of this Act and specifies the powers and duties of such Authority. The appropriate Authority of a specified country or a person, institution or other body who claims that a child has been wrongfully removed to and retained in Sri Lanka may apply to the Central Authority for assistance in securing the return of such child. The Authority may apply to the High Court of the Western Province for an order ordering the return of such child to the specified country in which he or she habitually resided.

Where the High Court is satisfied that the child has been wrongfully removed to and retained in Sri Lanka and less than a year has elapsed between the wrongful removal and the application, it shall forthwith order the return of the child to the country where he/she habitually resides. It may also do so even where more than one year has elapsed since the removal of the child, unless it is satisfied that the child is settled in his or her new environment.

The Court may refuse to order the return of the child if the person or institution from whom the child was taken was not exercising rights of custody at the time, or had subsequently consented to or acquiesced in the removal of such child, or where there is grave risk that the child's return may expose him/her to physical or psychological harm or otherwise place him/her in an intolerable situation. The Court may also refuse the application if the child objects to being returned and if the Court is satisfied that the child has reached an age and degree of maturity where his/her views should be taken into account.

An order made by the High Court shall not be deemed to be a determination on the merits of any issue of custody of the child. Where the Central Authority has received a notice that a child has been wrongfully removed to Sri Lanka from a specified country, no court in Sri Lanka shall make such a determination until after the High Court or the Central Authority has refused an application to return a child to that country, or until six weeks have passed since the date of such notice and no application for the return of the child has been made.

The Court must dispose of an application within six weeks of its date. Where the Court fails to do so, the Central Authority may request from it reasons for the delay. The Authority may do so on its own volition or on the request of the appropriate authority in the specified country. Where an order has been made for the return of a child, the Central Authority shall facilitate such return.

Where any person, institution or other body in Sri Lanka claims that a child has been wrongfully removed from the country, and is residing in a specified country in breach of the rights of custody of that person or institution or body, such person, institution or body may apply to the Central Authority for assistance to ensure the return of the child to Sri Lanka. The Central Authority shall apply to the appropriate Authority in the specified country in which the child is residing for assistance in securing his/her return to Sri Lanka. 


\section{REGULATIONS}

\section{United Nations Regulations No. 1 of 2001 (dated 11 October 2001)}

These Regulations were made by the Minister of Foreign Affairs under the United Nations Act No. 45 of 1968. Section 2 (1) of the Act provides that

If, under Article Forty-one of the Charter of the United Nations signed at San Francisco on the twenty-sixth day of June, Nineteen hundred and forty-five, (being the Article which relates to measures not involving the use of armed force) the Security Council of the United Nations call upon the Government of Sri Lanka to apply any measures to give effect to any decision of that Council, the Minister in charge of the subject of Foreign Affairs may by regulations make such provision as appears to him necessary or expedient for enabling those measures to be effectively applied, including (without prejudice to the generality of the preceding provisions of this subsection) provision for the apprehension, trial and punishment of persons offending against the regulations.

Clause 2 of the Regulations states "The Security Council of the United Nations acting under Chapter VII of the Charter of the United Nations, unanimously adopted Resolution 1371 (2001) and has re-affirmed the principle established by the General Assembly in its declaration of October 1970 (Resolution 2625 (XXV) and reiterated by the Security Council in its Resolution 1189 of $18^{\text {th }}$ August 1998, namely, that every State has the duty to refrain from organizing, instigating, assisting or participating in a terrorist act in another State, or acquiescing in organized activities within its territory directed towards the commission of such act and has decided that all States take necessary and effective measures to give effect to such decision."

These regulations were passed to give effect to this Resolution.

The Minster is empowered to appoint a Competent Authority by name or by office for the purpose of these Regulations. The Minister may also, in consultation with the Minister in charge of Defence, issue the necessary directions to implement these regulations. On information received, he/she, in consultation with the Minister in charge of Defence, shall determine the organizations or person in respect of whom these Regulations should be enforced, inform the Competent Authority of such determinations and forward to him/her the material on which the determination was made.

The Regulations prohibit any citizen of Sri Lanka (whether living in Sri Lanka or not) or any non-citizen living in Sri Lanka from doing any act which may directly or indirectly assist in the collection of funds for any terrorist organization or which may assist in any terrorist act. The funds, financial assets or resources of any person who engages in these acts shall be frozen with immediate effect.

No person shall within Sri Lanka make available, directly or indirectly, any funds or financial or economic resources for the benefit of any person or organization engaged in or attempting to engage in any terrorist act. 
Any person who contravenes these provisions shall, on conviction by the High Court of Colombo be liable to imprisonment for a minimum period of five years and a maximum period of ten years. His/her funds, financial assets or resources shall also be forfeited to the State.

If any person knows or to has reasonable cause to believe that any person has committed an offence under these regulations or is about to do so, or has information relating to the movement or whereabouts of any such person, he/she must report it to the police. Failure to do so is an offence which carries a punishment of imprisonment of between two and seven years on conviction.

The term "terrorist act" has also been defined in the Regulations. It includes the use or threat of actions which involves:

(a) the use or threat of action which is designed to influence the government, or to intimidate the public or a section of the public;

(b) the use or threat of action which is made for the purpose of advancing a political, religious or ideological cause;

and that the action envisaged

(i) involves serious violence against a person;

(ii) involves serious damage to property;

(iii) endangers the life of another person, other than the person committing the action;

(iv) creates a serious risk to health or safety of the public or a section of the public; or

(v) is designed seriously to interfere with or seriously to disrupt an electronic system.

"Terrorist organisation" means an organisation:

(a) which does any act, or causes any act to be done; or

(b) which is directly or indirectly connected with the collection of funds, and which assists, promotes or facilitated or is intended to assist, promote or facilitate the commission of a terrorist act.

\section{NATIONAL LAWS ON INTERNATIONAL LAW MATTERS}

\section{Mutual Assistance in Criminal Matters Act No. 25 of 2002}

The long title to this Act states that it is meant to provide for the rendering of assistance in criminal matters by Sri Lanka and specified countries and for matters connected therewith or incidental thereto.

This Act applies primarily in respect of any Commonwealth country which the Minister may declare by Order published in the Gazette.

Where an agreement has been entered into between Sri Lanka and any nonCommonwealth country, (whether before or after this Act), the Minister may by Order published in the Gazette declare that the provisions of the Act shall apply to such country. The Order shall specify the limitations and conditions which the Minister 
may decide to specify in the Order, having regard to the terms of the agreement. Every such order shall specify the terms of such agreement on which it was based. The Order shall remain in force only so long as the agreement remains in force.

All Orders in relation to any country (i.e., a specified country) shall be brought before Parliament as soon as convenient.

According to Section 3, the object of the Act is to facilitate the provision and obtaining by Sri Lanka of assistance in criminal matters, including:

(a) the location and identification of witnesses and suspects;

(b) the service of documents;

(c) the examination of witnesses;

(d) the obtaining of evidence, documents or other articles;

(e) the execution of requests for search and seizure;

(f) the effecting of a temporary transfer of a person in custody to appear as a witness;

(g) the facilitation of the personal appearance of witnesses;

(h) the provision of documents and other records;

(i) the location of the proceeds of any criminal activity;

(j) the enforcement of orders for the payment of fines or for the forfeiture or freezing of property.

The Secretary to the Ministry of Justice shall be the Central Authority for the purposes of this Act.

The appropriate authority of a specified country may make an application to the Central Authority requesting assistance in elation to a criminal matter failing within the jurisdiction of a criminal court in that country. Such a request may be refused wholly or partly if the Central Authority believes that the request relates to an act or omission that falls within any of the following categories.

(a) It would not constitute an offence under Sri Lankan law;

(b) The offence is of a political character;

(c) The act or omission would constitute an offence only under the military law of Sri Lanka.

The request may also be refused if it relates to the prosecution of a person for an offence for which that person has already been acquitted or convicted under Sri Lankan law. If compliance with the request would be contrary to the Sri Lankan Constitution or be prejudicial to the national security, international relations or public policy it could also be refused. Another basis for refusal would be where compliance would facilitate the prosecution or punishment of any person on account of his/her race, religion, language, caste, sex, political opinion or place of birth,

The Act makes provision for the following:

(a) Part II - assistance in relation to location and identifying persons;

(b) Part III - assistance in relation to the service of summons and other documents; 
(c) Part IV - assistance in relation to taking of evidence and production of documents or other articles;

(d) Part V - arrangements for persons to give evidence or assist investigations;

(e) Part VI - assistance in relation to search and seizure;

(f) Part VII - tracing proceeds of crime and enforcement of orders.

\section{OTHER RELEVANT STATE PRACTICE}

\section{Recommendations of the Human Rights Commission}

\section{Voting rights of migrant workers}

The Human Rights Commission of Sri Lanka Act No. 21 of 1996 established the Human Rights Commission which consists of five members appointed by the President on the recommendation of the Constitutional Council. The Commission has a wide mandate and provides an alternative system to the judicial process in protecting human rights. The Commission's functions are to investigate complaints regarding the infringements or imminent infringements of fundamental rights, and to provide for the resolution of such complaints by conciliation and mediation.

The Commission's mandate also includes advising and assisting the government in drafting legislation as well as administrative directives and procedures, to strengthen and protect fundamental rights. It can also advise the government on necessary measures to ensure that national laws and administrative practices conform to international human rights norms and make recommendations to the Government on the need to accede to treaties and other international instruments in the field of human rights.

A significant recommendation was made by the Commission in the year under review in response to an application filed by a trade union, the National Workers' Congress, on behalf of migrant workers. ${ }^{84}$ These workers number about one million and their earnings abroad now amount to one of the three highest sources of foreign exchange for the country. One of their long-standing demands was to be granted overseas voting rights while employed abroad.

In response to the application, the Commission recommended that Sri Lankans who have left the country to take up employment overseas and who intend to return to Sri Lankan within five years be given overseas voting rights. The Commission based its recommendation on the fact that Sri Lanka is a signatory to the United Nations Convention on the Protection of the Rights of All Migrant Workers and Members of their Families, and referred to Article 41 which addresses this issue.

\footnotetext{
${ }^{84}$ Information obtained from "Human Rights" a publication of the Ministry of Justice, Law Reform and National Integration, Volume 2002, Issue No. 3.
} 


\section{TAJIKISTAN ${ }^{85}$}

\section{JUDICIAL DECISIONS ${ }^{86}$}

\section{The Constitutional Court of the Republic of Tajikistan Resolution of the Constitutional Court of the Republic of Tajikistan, 12 June $2001^{87}$}

ESTABLISHMENT OF THE ACCORDANCE OF ARTICLES 329.5 AND 339.2 OF CRIMINAL PROCEDURE CODE TO THE CONSTITUTION OF TAJIKISTAN ${ }^{88}$

The Constitutional Court having considered the report of the Judge of the Constitutional Court, and having investigated the materials of the case, established:

The Supreme Court of the Republic of Tajikistan on the basis of requirements set by Article 33 of Penal Code, and fulfilling its authority to take to its own deliberation the cases of particular complexity or cases of special social importance, in its verdict of 24 November 2000 declared S.S. Sharipov guilty of the charges provided in Articles 186.1, 249.4 clauses (b) and (c), 181.3 clause (a), and 110.3 clause (a). In the verdict of 9 April 2001 the court also declared guilty B.I. Minboev of the commission of crimes according to Articles 104 and 195.1 of the Penal Code. In relation to both, the Supreme Court imposed the exceptional form of punishment: the death penalty.

According to Article 329.5 of the Criminal Procedural Code decisions of the Supreme Court are not subject to the cassational appeal and protest; those sentenced do not have the opportunity of bringing a cassational appeal against the decisions of the Supreme Court of Tajikistan. As a consequence, the constitutionality and substantial nature of its decisions remain unmonitored. Additionally, in accordance with Article 339.2 of the Criminal Procedural Code of Tajikistan, the question of the presence of the person sentenced during the deliberation of the court in examining the case regarding a cassational order is resolved by the same court. Furthermore, according to the same Criminal Procedural Code, authorities, namely the chairman of the Supreme Court and the General Prosecutor, have the right to enter a protest against the verdict, while the individual sentenced does not possess this right.

\footnotetext{
85 Contributed by Tahmina Karimova, Intern, International Criminal Court, The Hague.

${ }^{86}$ The Tajik Judicial System stands for a well structured and complex organization. The Constitutional Court, Supreme Court and Supreme Economic Court are set at the top of the judicial hierarchy in accordance with the Constitution of Tajikistan. Each of the courts has its own place in the system and is endowed with competencies that are pertinent exclusively to it. [Article 1 of the Law "On Constitutional Court of Republic of Tajikistan”, adopted 2 November 1995 Ahbori Majlisi Olii Jumhurii Tojikiston (Registry of the Tajik Parliament) Issue 21, p. 223].

87 Article 47 of the Law on Constitutional Court states that Resolutions of Constitutional Court cannot be appealed against.

88 NB Unofficial Translation of the Case cited in the "Collection of the Legal - Normative Acts and the Decisions of Constitutional Court of Republic of Tajikistan" (Sbornik Normativno-pravovih Actov i Resheniy Konstitucionnogo Suda Respubliki Tadjikistan), Dushanbe 2002
} 
The persons sentenced have pleaded before the court that they take partial responsibility for the commission of the crimes. According to their statements the investigation was conducted unilaterally; they were accused without sufficient evidence, and despite this fact they indeed have the right through a cassational order to appeal against the verdicts. This has not been granted and therefore their constitutional rights have been violated.

The sentenced S.S. Sharipov pleaded before the Constitutional Court through his legal representative that Article 329.5 should be proclaimed unconstitutional and as one without further legal effect. Additionally, Minboev with the help of his counsel appealed to the Constitutional Court of Republic of Tajikistan and requested the determination of Articles 329.5 and 339.2 of the Criminal Procedural Code as being non-compliant with the Constitution and thus without further legal effect.

The special representative of the Majlisi Namoyandagon of Majlisi Oli (lower house of the Tajik Parliament) M.Z. Rahimov explained that the Criminal Procedural Code of Tajikistan was adopted in 1961 and some of its articles do not meet the requirement of the Constitution and international standards recognized by Tajikistan. The Constitutional Court having investigated the disputed matters had come to the resolution that according to Article 17 of the Tajik Constitution each person is equal before the law and the court.

Furthermore, in accordance with Article 19.1 each person has a guarantee of judicial defence, and has a right to claim that his case be adjudicated by a competent and impartial court. The right to appeal against the judicial decisions is one of the democratic principles of criminal procedure; relying upon this principle and according to Article 329.1 of the Criminal Procedural Code, all participants of criminal procedure have a right to freely appeal against the decisions of court in cassational order.

To appeal regarding a cassational order is one of the means of assessing the legality and substantial nature of judicial decisions. It is directed at the timely disclosure of the committed violations of law, at verification of the implementation of the presumption of innocence principle, and at application of the law in High Instances, in order to ensure that crimes do not remain unpunished and the innocent are not charged wrongly for crimes they did not commit.

Whilst examining the case in the first instance, the Supreme Court is under the duty to provide the defendant simultaneously with the opportunity to realize the democratic principles concerning cassational instance, i.e., the right freely to appeal against the sentence, verification of the legality and substantial nature of sentences, provision of new evidence, etc.

In accordance with Article 20 of the Constitution of the Republic of Tajikistan no one is recognized as being guilty of having committed a crime prior to the moment the court decision is given legal effect; i.e., in accordance with the general rules of court examination, if no appeal or protest is brought against the latter within the time limit of seven days, then it comes into legal effect. Hence, the instance of cassation represents one of the most important stages of the judicial process and must be exercised. However, Article 329.5 of the Criminal Procedure Code of Tajikistan deprives the person sentenced of his right to appeal against the court decision and 
this circumstance is contradictory to the provision of Articles 17, 19 and 20 of the Tajik Constitution.

Moreover, Article 10.3 of the Tajik Constitution provides that international legal norms recognized by Tajikistan are a part of the legal system of Tajikistan. In the case of contradiction of Tajik laws with international legal acts, the latter have priority over the former.

According to the International Covenant of Civil and Political Rights adopted by UN GA Resolution (XXI) of 16 December 1966 and on the basis of the Resolution adopted by Majlisi Oli of the Tajik Republic from 1 November 1998, this Covenant has been in force in the territory of Tajikistan since 4 April 1999. In particular Article 14.5 of the Covenant provides that "every one who is sentenced for commission of a crime has a right for the sentence to be revised by the higher judicial instance in accordance with law".

Article 339.2 of the Criminal Procedural Code provides that court of cassational instance can decide whether the sentenced can take part in the court examination. In the event that the sentenced is not given such an opportunity, he is deprived of making use of the procedural rights provided by Articles 341-342 of the Criminal Procedural Code. These procedural rights include: the right to reject, the right to speech and to provide additional materials, or the right to revise materials provided by third parties; also, the person sentenced can be deprived of the right to be informed of the conclusion of the prosecutor. Such circumstances illustrate a violation of the requirement of Article 17 of the Constitution that provides equality of everyone before the law. The state of affairs also contradicts Article 88 of the Constitution that guarantees contestation and the equality of parties.

Further, according to Article 14.3 of International Covenant on Civil and Political Rights every one has a right as minimum for the following equal guarantees when he is charged with a criminal offence:

"d) to be tried in his presence, and to defend himself in person or through legal assistance of his own choosing".

Taking into account the above and other circumstances expressed in relation to the sentenced, he has as much a right to appeal in cassational order against the decision of the Supreme Court as do the other parties.

On the basis of the abovementioned, the Constitutional Court of the Republic of Tajikistan has come to a resolution to recognize Article 329 part 5 of the Criminal Procedural Code to be contradictory to Articles 17, 19 and 20 of the Constitution and therefore of no further legal effect. Moreover, all the normative acts that were based on Articles 329.5 and 339.2 of the Criminal Procedural Code or contained the provisions of these Articles should be considered as void. 


\section{NATIONAL LAWS ON INTERNATIONAL LAW MATTERS}

\section{Law "On the Usage and Protection of the Red Cross and Red Crescent Emblems and Appellations in the Republic of Tajikistan" adopted on 12 May $2001^{89}$}

In accordance with the international obligations of the Republic of Tajikistan that flow from the Geneva Conventions on the Protection of the Victims of War of 12 August 1949 and Additional Protocols to them, and also according to the Rules of using the emblems of Red Cross or Red Crescent by national societies, ${ }^{90}$ Tajikistan has enacted relevant law that regulates the usage and protection of the emblems of the Red Cross and the Red Crescent. The law accepts the same definitions of an armed conflict, medical personnel, sanitary and transport means and emblem as provided in the Geneva Conventions and Additional Protocols.

The objects that fall under the protection of the above-mentioned law are: the emblems of the Red Cross and the Red Crescent; the appellations "Red Cross" and "Red Crescent"; and distinguishing symbols identifying medical personnel and sanitary/transport means. Article 5 of the law provides that the emblem is the symbol of alleviation of the suffering of the wounded and sick in times of armed conflicts and emergency situations.

The emblem can be used only in circumstances envisioned in the law, Geneva Conventions and Additional Protocols. The emblem is specifically used as a protection sign in times of armed conflict and is used to distinguish medical personnel, medical and sanitary transportation in peacetime.

The law further refers to the usage of the emblem of the Red Crescent by the medical services of the armed forces of Tajikistan, other armed formations, by the civil medical service and by the national societies of the Red Cross and the Red Crescent; additionally, it determines the distinguishing symbols used by medical and sanitary transportation of the Red Cross and Red Crescent societies.

The usage of the emblem in contradiction to the law is a violation and hence criminal responsibility is provided for.

\section{Law “On the Import and Export of Cultural Valuables" adopted 31 July 2001"}

The law establishes a legal framework aimed at the preservation of the cultural heritage of peoples, the protection of cultural valuables from illicit import and export, the establishment of unified procedure of import and export, and at facilitating international cooperation in the field. It is provided that in cases where the present

\footnotetext{
89 Ahbori Majlisi Olii Jumhurii Tojikiston (Registry of the Tajik Parliament for 2001) Issue \#4, 2001, pp. 202-205.

${ }^{90}$ Adopted in the International Conference of the Red Cross and the Red Crescent in 1965, with amendments from 1991.

${ }^{91}$ Ahbori Majlisi Olii Jumhurii Tojikiston (Registry of the Tajik Parliament) Issue \# 7 p. 511
} 
law contradicts international treaty provisions ratified by Tajikistan, the latter will take precedence over the former.

The following cultural objects fall within the jurisdiction of the Act:

- cultural valuables created by nationals of Tajikistan;

- $\quad$ valuables created in the territory of Tajikistan by foreign nationals or by persons without a state;

- cultural objects found in the territory of Tajikistan;

- valuables collected in museums, libraries, archives, and galleries;

- cultural objects acquired by archaeological, ethnographical, folklore and by any other scientific expeditions;

- valuables acquired as a result of voluntary exchange;

- cultural objects received as a part of an inheritance or gift, or legally acquired with the agreement of the authorized agencies of a state to which cultural valuables belong; and

- cultural valuables imported to Tajikistan by foreign corporate bodies.

The Ministry of Culture and the Customs Committee are the two state agencies authorized by the Act to deal with the cases in the sphere of import and export of cultural valuables. More specifically, the Ministry is competent to specify categories of objects that qualify as a cultural valuable and is authorized to decide matters of import and export. It is in charge of the registration of imported and exported cultural valuables and additionally takes other measures relevant to the fulfilment of the abovementioned competencies. The Customs Committee exercises control over the importation and exportation of the cultural objects.

The owner or other authorized person of the cultural valuable can export the object on the basis of a certificate granted by the Ministry of Culture. It is forbidden to export cultural valuables created more than 50 years ago, objects that are registered in the state protection books, and objects that are permanently kept in state and public museums, archives and libraries.

The law allows temporary export of cultural objects for the purposes of international exhibitions, restoration and scientific research or export of valuables related to theatrical or artistic activity, etc. Temporarily exported cultural objects cannot be used as a credit guarantee or as an object of bail.

The Tajik diplomatic corps provides protection to temporarily exported cultural valuables. Objects that are aimed at subverting the constitutional system and state sovereignty or the violation of territorial integrity, objects that propagate war, terrorism, violence, religious extremism, racism and, additionally, materials of pornographic content cannot be brought into Tajikistan in the guise of cultural objects.

The law regulates the prevention of illegal import and export of cultural valuables and sets the legal framework for the transit of cultural objects, considering additionally their postage via mail. Finally, the Act sets the rules on returning cultural objects to Tajikistan and the process of compensation to bona fide owners of the returned cultural valuables. 


\section{Law “On Informing (Informatization)” adopted on 6 August 2001"}

The Tajik authorities have endeavoured to create positive conditions in order to satisfy informational demands of corporate bodies, individuals and state agencies. Therefore, it was deemed essential to create a modern informational infrastructure that will be integrated into the international informational system. These and other reasons necessitated the adoption of a law that will regulate the legal conditions of the formation and utility of documented information and informational resources. The Act has established a legal framework for the creation of informational technology and for the determination of rights and duties of subjects taking part in the process of informing in society.

The law anticipates a new concept, i.e., "informatization" to understand the process of elaboration, creation and development of the informational technologies and resources. The so-called informatization is based on the principles of accessibility of information, and the effectiveness, completeness and precision of the presented information. Additionally, the law provides for the protection of property in the informational sphere.

The law outlines the responsibility of the state. The foremost obligation of the state in the field is to create necessary legal, economic, organizational and other conditions that will facilitate the development of informatization, at the same time bearing in mind the rights and interests of individuals.

The functions of state agencies in the sphere of informatization are confined to the creation of conditions for the comprehensive fulfilment of informational needs of the population, national informational structure facilitation, and the granting of support to the development of international and universal information network and systems, etc. The law provides that the objects of ownership in the sphere of informatization are informational resources, documented information, informational technology, a complex of programme and technical means and, in addition, informational systems and networks.

It must be noted that the law on "informatization" lays down a very comprehensive set of rules in the field of informatization and attempts to cover all significant areas in the field so as to provide a well-structured legal regime.

For instance, Chapter II of the Act is dedicated to the informational resources area. The law envisions that informational resources should primarily be used to satisfy the informational needs of society and state and should be directed at the establishment of unified informational space and its integration into the international informational community. The Chapter outlines the basics of the legal regime for informational resources and further specifies the directives on the usage of documented information.

However, the implementation of the right to receive information may not violate the civil, political, economic, social, spiritual and other rights and legal interests of other individuals and corporate bodies. Informational resources are classified according

${ }_{92}$ Ahbori Majlisi Olii Jumhurii Tojikiston (Registry of the Tajik Parliament for 2001) Issue \# 7 p. 502. 
to their level of accessibility. State informational resources are open and accessible, with the exception of information that is confined by the law to the category of "limited access".

Another significant part of the law on informatization is dedicated to infrastructure and informational systems. Particular attention is also given to the protection of informational resources and the rights of subjects in the sphere of information. The latter represents a very significant component in the development of such an area as information, since it provides protection from illegal interference in informational resources, and from unauthorized acts directed at the copying, modification, destruction, etc. of the information. However, the above-mentioned does not represent an exhaustive list of objectives to be achieved. Furthermore, protection is essential in order to preserve the precision, completeness, integrity of documented information, to protect the constitutional rights of individuals against any violation of confidentiality and private life, and additionally to preserve state secrecy, and lastly and generally, the rights of subjects participating in legal conditions concerning information.

Since information has become a significant part of international cooperation, the legislators have contemplated provisions regulating bilateral and multilateral cooperation in the area of information. Integration into international informational network is encouraged and relevant measures of precaution and protection from illicit acts are regulated.

\section{Law "On the Status of Refugees" adopted on 10 May $2002^{93}$}

As part of the implementation of its obligation in accordance with the International Convention on the Status of Refugees of 28 July $1951,{ }^{94}$ Tajikistan has adopted its second legislative act on "The Status of Refugees". ${ }^{95}$ The previous law on the same matter adopted in July 1994 was subsequently declared as being without further legal effect.

The law provides provisions envisioning the scope of the Refugee Law. The law provides the definition of a "refugee", which does not differ substantially, except for the technical differences, from the definition provided in the Convention.

The law on Refugees identifies categories of people that are excluded from the scope of refugee status. These categories include:

1. persons who have allegedly committed crimes against peace, war crimes or crimes against humanity;

\footnotetext{
93 Ahbori Majlisi Olii Jumhurii Tojikiston (Registry of the Tajik Parliament for 2002) Issue \# 4 part I, p. 305.

94 Ratified by the Government of Tajikistan in 1993.

${ }^{95}$ Rights of Refugees: International and National Standards, (compilation of international conventions and Tajik Law relating to the status of refugees) eds. UNHCR, Ministry of Labour and Social Protection of Tajikistan and "Law and Society" NGO. Dushanbe-2002 pp. 109-128.
} 
2. persons against whom there are reasons to assume that they have committed serious crimes of non-political character beyond territory of Tajikistan prior to their seeking of the status of a refugee;

3. persons who are allegedly connected to the special agencies of their country of nationality, to international terrorist organizations or to drug-dealing structures;

4. persons in relation to whom there are reasons to purport that they are guilty of misconduct contravening with the principles and goals of UN organization and OSCE.

Furthermore, the law provides the details of the procedure of recognizing a person as a refugee. The subsequent provisions of the Act reflect the rights and duties and the most important guarantees available to a refugee. The guarantees include the principle of non-refoulement.

\section{Law “On the Electronic Document” adopted on 10 May 2002 ${ }^{96}$}

The Law on the Electronic Document is the first legal act adopted in the sphere in Tajikistan. It establishes the legal basis of electronic document management, lays down the rules governing the basic requirements of such documents, and envisages the rights and duties of the parties in the context of relations resulting from the circulation of electronic documents.

According to this Act, an electronic document is allowed to be used in all the spheres involving informational and technical means that are necessary for the preparation and preservation of incoming and outgoing information. More specifically, electronic documents can be used in the conclusion of contracts, payments, carrying on correspondence and information transmission.

The law underlines the necessity for control and regulation in this sphere in order to ensure the protection of the rights and legal interests of the subjects and to ensure the protection of information as well. For this purpose the government of Tajikistan is endowed with the right to control the field of circulation of the electronic document.

A set of requirements must be met by a document in order for it to qualify as an electronic document. The first and foremost requirement is that the electronic document must be created, worked on, received and sent by technical and programming means. Further, the Act establishes the structure, and external and internal form of the electronic document.

The electronic document possesses the same legal effect as the hard format of the document. However, the reflection of the electronic document on paper, i.e., copy of electronic document must be appropriately certified in order to provide this with the legal effect. The law regulates other aspects of electronic format such as digital signatures, and lays down detailed rules dealing with the purpose and usage of personal keys to the signature.

96 Supra, n. 15, at p. 308. 
Dissemination of the electronic document that contains state, commerce or other types of secret and other information is forbidden or limited by the law. As a consequence, state agencies, corporate bodies and individuals that use the above-mentioned information are obliged to transmit such documents through certified and protected connection channels.

Furthermore, the law on electronic documents encompasses such areas as the licensing of the circulation of electronic documents and provides provisions regulating circulation of the e-documents in banking activity. Violation of the provisions of the law and dissemination of the information of limited access is penalized. The concluding part of the law envisions international cooperation in the sphere of electronic documents.

\section{Law “On Information Protection” adopted 2 December 2002}

The role of information as a significant and major determinant of modern society is indisputable. Hence, realizing the threat of the information's being leaked, misappropriated, distorted, forged, illegally blocked, copied, etc., appropriate legal frameworks have been drawn up. The law on information protection establishes the fundamental principles of protection and regulates the legal conditions that emerge in this area.

The object of the legal protection provided in the present law is the documented information in relation to which certain rules and limitations have been set by the Tajik laws for the owner or proprietor. The latter is being further specified in terms of subjects of the legal conditions mentioned: that is, state institutions, corporate bodies and individuals can act in the capacity of proprietor. Moreover, it is anticipated that the subjects of legal conditions in the area of information have rights for protection from acts resulting in the destruction, misappropriation, and modification of information.

It is established by the law that organizational, technical, physical and cryptographical means can be used as a means of protecting the information. It is emphasized by the Act that authorized state agencies need to undertake protection through the administration of a unified technical policy on information protection. The implementation of such a policy in the area should be accompanied by a number of other measures and rules specified further in the law.

\footnotetext{
${ }^{97}$ Ahbori Majlisi Olii Jumhurii Tojikiston (Registry of the Tajik Parliament for 2002) Issue \# 11, p. 696
} 


\section{OTHER RELEVANT STATE PRACTICE}

\section{Decree No. $855^{98}$}

Presidential Decree No. 855, called otherwise "humanization of the criminal law" relating to "Reformation of Criminal and executive system of Tajikistan" was issued in July 2002. Aiming at the promotion of respect for human rights and improvement of the system of criminal punishment, it was established by the decree to start a transmission of the authority over criminal cases from the Ministry of Internal Affairs to the Ministry of Justice. Such a transmission requires a detailed and comprehensive legal regulation. Therefore, the Presidential Decree has also requested legislators to ensure adoption of relevant laws in fulfilment of the decree and to assist in the facilitation of reforms in the area of criminal law.

\section{THAILAND $^{99}$}

\section{JUDICIAL DECISIONS}

\section{Extradition; Political offence exception}

\section{PUBLIC PROSECUTOR v. SOK YOUEN A.K.A. SOK YUEN}

[Black Case No. Phor. 6 / 2543; Red Case No. Phor. 7 / 2545, 28 November 2002, CRIMINAL COURT, JJ. POL ANUWATNITIKARN and TERDSAK INTARAPREECHA]

The Defendant was accused by the Cambodian authorities of committing two offences: (a) the attempted murder of Prime Minister Hun Sen of Cambodia on 24 September 1998, as a result of which some houses were damaged, one child killed and three other persons injured; and (b) the illegal possession of weapons of war. The Cambodian military court issued a warrant for his arrest. The first offence is punishable with imprisonment of ten to twenty years, while the second one is punishable with imprisonment of six months to three years. The Defendant went into hiding in Cambodia and, a year later, escaped to Thailand. The Cambodian Government sought his extradition from Thailand in a series of diplomatic notes addressed to the Thai Ministry of Foreign Affairs in 1999 and 2000.

Pursuant to Section 4 of Thailand's Extradition Act B.E. 2472 (1929 A.D.), the Royal Thai Government may at its discretion surrender to foreign States with which no extradition treaties exist persons accused or convicted of crimes committed within the jurisdiction of such States, provided that by Thai laws such crimes are punishable

${ }_{98}$ Data provided by the Ministry of Justice of the Republic of Tajikistan.

99 Contributed by Patcharapa Thawinyarti, Barrister-at-Law, Bangkok. 
with imprisonment of not less than one year. Under Section 8, unless the Royal Thai Government decides otherwise, the extradition request together with the accompanying documents shall be transmitted to the Ministry of Interior in order that the case may be brought before the Court by the Public Prosecutor. Section 12 (3) stipulates that the offence for which extradition is sought must not be of a "political character". Section 17 makes clear that appeals in extradition cases lie with the Court of Appeal whose decision on all questions both of fact and of law shall be final.

There was no extradition treaty between Thailand and Cambodia in force at the time of the extradition request. The offences allegedly committed by the Defendant are punishable under the law of Thailand with imprisonment of not less than one year.

The Defendant argued, inter alia, that the crimes for which he was being sought by Cambodia were not ordinary crimes. The target of the alleged attempted murder was the Prime Minister of Cambodia, who had been in power for twenty-one years. Any person attempting to murder the Prime Minister, contended the Defendant, must have had ulterior political motives to overthrow the Government of Cambodia. The Defendant himself was a member of an armed group that fought Prime Minister Hun Sen's group during the armed conflict in Cambodia prior to the United Nationssupervised general election in 1993. Hence, the Defendant argued, the offences were of a political character. He further contended that his extradition was being sought for him to be punished for his membership of a political party in the Opposition in which he had played a leading role. Once in the hands of the Cambodian authorities, according to the Defendant, he would be compelled to implicate the leader of that opposition party as the mastermind of the attempted murder. He also argued that extraditing him to Cambodia would violate both his right to a fair trial before an impartial tribunal under Article 10 of the Universal Declaration of Human Rights of 1948, Article 14 of the International Covenant on Civil and Political Rights of 1966, as well as his refugee status granted by the UNHCR under Article 33 of the United Nations Convention relating to the Status of Refugees of 1951.

The Criminal Court held that the Defendant was the person named in the extradition request, that his offences were extraditable offences under the Extradition Act of 1929, and that the Royal Thai Government had decided to exercise its discretion to extradite the Defendant to Cambodia.

The Criminal Court then dealt at length with the Defendant's contention that his offences were of a political character. The Criminal Court alluded to the fact that there had been armed conflicts in Cambodia up to the Paris Conference of 1991 which resulted in the United Nations-supervised general election in 1993, and that after that election political situations were far from peaceful. There were clashes among opposing parties and Prince Norodom Ranaridth, Prime Minister Hun Sen's Co-Prime Minister, and Mr. Sam Rainsy, leader of the political party to which the Defendant belonged, had to escape from Cambodia. The United Nations had to organize another general election in 1998, with Mr. Hun Sen emerging as the winner. Prime Minister Hun Sen was on his way to take an oath as the newly elected and only Prime Minister of Cambodia when he and his entourage were fired upon allegedly by the Defendant. The Criminal Court reasoned that the assassination of a head 
of government would result in a change of the person of the head of government but not in a change in a political regime under a political party system of democracy. Therefore, even assuming for the sake of argument that the Defendant had political motives in committing his crimes, by deciding that such offences were of a political character the Court would seriously endanger the safety of Heads of State. It came as no surprise that the International Law Association resolved in 1892 that ordinary offences with political motives such as murder and attempted murder shall not be deemed political offences. Moreover, the Treaty between the Kingdom of Thailand and the Kingdom of Cambodia on Extradition, signed in Bangkok on 6 May 1998, provides in Article 3 (1) that a political offence for which the Requested State shall not grant an extradition "shall not include the taking or attempted taking of the life or an attack on the person of a Head of State or a Head of Government or a member of his or her family". Although the Treaty was not then in force at the time of the extradition request in this case, it manifested the intention of the two States to adhere to the aforesaid principle in accordance with State practice, which treats this kind of offences as ordinary crimes of a terrorist nature. The Court also rejected the Defendant's contention that he would be compelled to implicate the leader of his political party. This was because the Defendant himself had conceded that two of his alleged accomplices who had been previously arrested by the Cambodian authorities were now acquitted by the Cambodian military court after the Prosecution's failure to present evidence to the military court within the requisite period of six months of their arrest, and that the two alleged accomplices had not been forced to implicate the leader of the Defendant's political party.

The next contention of the Defendant disposed of by the Criminal Court concerned the refugee status accorded to the Defendant by the UNHCR which, according to the Defendant, would protect him from being sent back to Cambodia where he had a well-founded fear of persecution. The Criminal Court, however, ruled that Thailand was not a State Party to the 1951 Refugee Convention and had no obligation to respect the provisions of the Convention.

Finally, the Criminal Court held that the Defendant's argument that he would not get a fair trial before an impartial tribunal in Cambodia was irrelevant to the extradition process. By virtue of Section 13 of the Extradition Act of 1929, the Court need not hear evidence for the accused in his defence except on the following: (1) that he is not the person wanted; (2) that the offence is not extraditable or is of a political character; (3) that his extradition is in fact being asked for with a view to punishing him for an offence of a political character; and (4) his nationality. Section 14 of the same Act provides that if there is insufficient evidence, the Court shall order that the accused be discharged. The right to a fair trial in the court of the Requesting State is therefore not a ground for the Court not to extradite the Defendant. Whether the Defendant was guilty as charged depended on the evidence before the court that tried him, and which court would try him depended on the law of Cambodia.

The Criminal Court stated, obiter, that the Defendant's fear that he would not get a fair trial might be unfounded. The Court opined that even human rights NGOs called by the Defendant as witnesses testified that the Cambodian legal and judicial 
systems had been reformed by the United Nations to comply with universal standards. The death penalty had been abolished. Judicial appointments had to be approved by the King. The Defendant would have the right to legal counsel and to appeal to a higher court. In the absence of sufficient evidence to prove his guilt, the Defendant would be set free as in the case of his two alleged accomplices. Besides, there were numerous human rights NGOs operating in Cambodia which would be ever ready to render assistance to the Defendant.

The Criminal Court was therefore satisfied that the evidence was sufficient for the Defendant's extradition, and made an order pursuant to Section 15 of the Extradition Act of 1929 authorizing him to be detained with a view to being extradited.

The Defendant subsequently lodged an appeal before the Court of Appeal. ${ }^{100}$

\section{OTHER RELEVANT STATE PRACTICE}

\section{Opinion of the Department of Treaties and Legal Affairs}

Vienna Convention on Diplomatic Relations of 1961; summons of foreign embassy personnel to appear as witnesses before a criminal court of the receiving State

In September 2001, the Criminal Court issued a summons for Mr. P., Attaché of the New Zealand Embassy in Bangkok, and Ms. B., clerk of the Embassy, to appear before the Court as witnesses. The Department of Protocol, Ministry of Foreign Affairs of Thailand, transmitted the summons to the Embassy by a diplomatic note.

The Embassy sent Diplomatic Note No. 2001/245 dated 5 October 2001 in reply. The Note stated that the Embassy, under instruction from the Ministry of Foreign Affairs and Trade Wellington, sought dispensations from the summons for the two said persons to appear before the Criminal Court. For Mr. P., dispensation was sought in his capacity as a diplomatic agent of the Embassy. For Ms. B., who is a Thai national, dispensation was sought on the grounds that such appearance as witness would be inconsistent with her role as an employee of the Embassy who takes instructions from the diplomatic agents of the Embassy. In other words, compelling Ms. B., a locally engaged staff member, to testify in court would interfere unduly with the performance of the functions of the Embassy in violation of the Vienna Convention on Diplomatic Relations of 1961.

The Department of Treaties and Legal Affairs, Ministry of Foreign Affairs of Thailand, adopted the following legal position on this matter in its Memorandum No. 0602/35/2545 dated 10 January 2002 in reply to the request for legal opinions from the Department of Protocol of the same Ministry:

Thailand and New Zealand are States Parties to the 1961 Convention. Article 1 (c) of the Convention defines "members of the mission" as "the members of the

100 The Court of Appeals rendered its judgment on 30 September 2003 upholding the judgment of the Criminal Court. 
diplomatic staff, of the administrative and technical staff and of the service staff of the mission". Therefore, both Mr. P. and Ms. B. are members of the New Zealand diplomatic mission in Thailand.

However, while the position of Mr. P. is covered by Article 37 (2) of the Convention, that of Ms. B. comes under Article 38 (2) of the same Convention.

By virtue of Article 37 (2), Mr. P., who is not a national of or permanently resident in Thailand, the receiving State, enjoys the privileges and immunities specified in Articles 29 to 35 of the Convention, including the exemption stipulated in Article 31 (2) from an obligation to give evidence as a witness.

Pursuant to Article 38 (2), Ms. B., who is a Thai national, enjoys privileges and immunities only to the extent admitted by Thailand, the receiving State, although Thailand must exercise its jurisdiction over Ms. B. in such a manner as not to interfere unduly with the performance of the functions of the New Zealand Embassy. Under Thailand's normal practice, which it considers consistent with customary international law, Thailand construes the proviso "in such a manner as not to interfere unduly with the performance of the functions of the mission" in Article 38 (2) of the Convention to mean that any measure taken by the receiving State should not affect important operations of the mission and/or should not cause serious inconvenience to the member of the mission subjected to such measure. In Ms. B.'s case, the Criminal Court summonses her to appear as a witness in her capacity as interpreter of an offender who is a New Zealand national. It is true that the New Zealand Embassy has assigned Ms. B. to be interpreter as part of the Embassy consular functions to protect the interests of New Zealand nationals. In this light, Thailand concedes that (a) Ms. B. can make a request not to testify on matters relating to official information acquired in the course of her employment at the Embassy, and that (b) if necessary, Ms. B. may request a hearing schedule to accommodate her convenience. Otherwise, Ms. B.'s appearance as a witness before the Criminal Court would not result in any undue interference with the performance of the functions of the New Zealand Embassy, but should be considered as an act of cooperation between Thailand and New Zealand in their diplomatic relations.

\section{International Agreement}

\section{Memorandum of Understanding between the Royal Thai Government and the Royal Government of Cambodia regarding the Area of their Overlapping claims to the Continental Shelf, 18 June 2001}

In 1972, Cambodia proclaimed the continental shelf boundary in the Gulf of Thailand. Thailand followed suit in 1973. Cambodia's claim overlapped those of Thailand and Vietnam.

On 9 August 1997, Thailand and Vietnam concluded the Agreement on the Delimitation of the Maritime Boundary between the Two Countries in the Gulf of Thailand, which entered into force on 27 February 1998. As a result of this Agreement, Vietnam no longer claims any maritime area which is also claimed by both 
Thailand AND Cambodia. The area under the Thai-Cambodian overlapping maritime claim is thereby narrowed down to approximately 26,000 square kilometres in all.

The most significant dispute between the two States lies in Cambodia's lateral maritime boundary line. The line is based on Cambodia's interpretation of Clause 1 of the Protocol annexed to the 1907 Franco-Siamese Treaty of 23 May 1907 which stipulates in its pertinent part: "The frontier between French Indo-China and Siam starts from the sea at a point opposite the highest point of the island of Koh Kut. From this point it follows a north-easterly direction to the ridge of Prom-Krevanh ..." Cambodia draws the boundary line starting from the terminus of the common land boundary between Thailand and Cambodia abutting the Gulf of Thailand in the direction of the highest point of Thailand's Koh Kut, located approximately 19 nautical miles offshore. The Cambodian boundary line then stops when it touches the eastern side of Koh Kut's landmass before the line continues its projection from the western side of the island's landmass in the same direction to the middle of the Gulf of Thailand where it meets the segment of Cambodia's median line drawn between the opposite Thai and Cambodian coasts in disregard of Thailand's major islands in the vicinity of the relevant Thai coasts. Thailand, on the other hand, interprets the said provision of the Protocol to mean that France and Siam (as Thailand then was) agreed on the course of the land frontier between Siam and French Indochina which started at the point opposite the highest point of Koh Kut. In other words, Koh Kut was intended as a point of reference for the land frontier which starts on the coast and then follows a north-easterly direction inland to the ridge of a mountain. Thailand also disputes Cambodia's median line drawn between the opposite coasts of the two States. Thailand considers its maritime boundary based on equidistance and median line equitable in light of the prevailing geographical circumstances of the two States. ${ }^{101}$

In 1978, Cambodia proclaimed an exclusive economic zone of 200 nautical miles measured from its baselines. Thailand followed suit in 1981. However, only Thailand proclaimed the geographical coordinates of the outer limit of the exclusive economic zone, on 16 February 1988. The coordinates coincide with those of the continental shelf proclaimed by Thailand in 1973 .

Thailand and Cambodia are States Parties to the four Geneva Conventions on the Law of the Sea of 1958. Neither of them is party to the 1982 United Nations Convention on the law of the Sea.

Article 74 (3) and Article 83 (3) of the 1982 Convention provide, inter alia, that pending agreement on the delimitation of the exclusive economic zone and the continental shelf, respectively between States with opposite or adjacent coasts,

[T] he States concerned, in a spirit of understanding and co-operation, shall make every effort to enter into provisional arrangements of a practical nature and, during this transitional period, not to jeopardize or hamper the reaching of the final agreement. Such arrangements shall be without prejudice to the final delimitation.

101 See Kriangsak Kittichaisaree, The Law of the Sea and Maritime Boundary Delimitation in SouthEast Asia (1987) pp. 37-41, 51-54, 63-66. 
Thailand and Malaysia had entered into this kind of provisional arrangements of a practical nature in their Memorandum of Understanding on the Establishment of a Joint Authority for the Exploitation and Exploitation of the Resources of the Sea-Bed in a Defined Area of the Continental Shelf of the Two Countries in the Gulf of Thailand, dated 21 February 1979. The 7,222 square kilometres of continental shelf disputed between the two States have become a joint development area (JDA) subject to the exploration and exploitation by the Joint Authority of the non-living natural resources for a period of fifty years commencing from the date of the entry into force of this Memorandum. Australia and Indonesia concluded similar arrangements in the Timor Gap in 1988, which are now superseded by the arrangements between Timor Lest and Australia.

With such precedents in mind, Cambodia proposed that Thailand and Cambodia enter into a joint development regime for the maritime area under their overlapping claims. Thailand was more circumspect, being convinced of the legal justifiability of its claim. The compromise appears in the Memorandum of Understanding between the Royal Thai Government and the Royal Government of Cambodia regarding the Area of their Overlapping Maritime Claims to the Continental Shelf, signed in Phnom Penh, Cambodia, on 18 June 2001 and in force on the date of its signature.

Under the Memorandum of Understanding ('MOU'), the Parties consider it desirable to enter into "provisional arrangements of a practical nature" in respect of the territorial sea, continental shelf and exclusive economic zone under their overlapping claims ("Overlapping Claims Area"). They intend, through accelerated negotiation, simultaneously to: (a) conclude an agreement for the joint development of the hydrocarbon resources located in the overlapping area below 11 Degrees Latitude North ("Joint Development Area"); and, as "an indivisible package", (b) agree on a mutually acceptable delimitation of the maritime area claimed by both Parties above 11 Degrees Latitude North ("Area to be Delimited"). The Area to be Delimited mostly involves the lateral delimitation between the Parties' adjacent coasts, including the maritime area in the vicinity of Thailand's Koh Kut. The MOU sets up a Joint Technical Committee, comprising officials of Thailand and Cambodia to be separately nominated, responsible for drawing up: (a) the agreed terms of the Joint Development Treaty, including a mutually acceptable basis for sharing the costs and benefits of the exploitation of hydrocarbon resources located in the Joint Development Area; and (b) an agreed delimitation of the maritime area between their respective current claims in the Area to be Delimited in accordance with applicable principles of international law. Subject to the entry into force of the delimitation of the Parties' respective maritime claims in the Area to be Delimited, this MOU and all actions taken pursuant to it are without prejudice to the maritime claims of either party.

In 2001 and 2002, the Parties met several times under the framework of the MOU, but could not reach any agreement on either the delimitation or the joint development. 


\section{Thailand and Laws to Counter International Terrorism ${ }^{102}$}

As a Member State of the United Nations, the Royal Thai Government is bound by Article 25 of the United Nations Charter, which stipulates that all Member States of the United Nations must agree to accept and carry out the decision of the Security Council in accordance with the Charter.

I. Thailand's domestic legal basis to implement the asset freeze required by UN Security Council Resolution 1267 (1999), and paragraphs 1 and 2(a) of UN Security Council Resolution 1390 (2002) as well as impediments under Thailand's domestic law in this context and steps taken to address them

- The Thai government has issued instructions to all authorities concerned to comply with UN Security Council resolutions on freezing of transfer of funds or financial resources belonging to the Taleban, Osama Bin Laden and Al-Qaeda network.

- Pursuant to the Money Laundering Act of 2000, financial institutions, government units under the Department of Lands and traders engaging in businesses involving the operation of or consultation in a transaction related to the investment or mobilization of capital are required to report any suspicious transactions to the Anti-Money Laundering Office.

- Section 3 of the Act defines "financial institution" as:

- The Bank of Thailand, a commercial bank and such banks as specifically established by law;

- Finance companies, credit financier companies and securities companies under the law on securities and stock exchange;

- The Industrial Finance Corporation of Thailand and small industrial finance corporations;

- Life insurance companies and insurance companies;

- Savings co-operatives; or

- Juristic persons carrying on such other businesses related to finance as prescribed in a Ministerial Regulation.

- Therefore, under the sixth definition, "financial institution" can be broadly interpreted to cover intermediaries outside the main financial sector.

- The penalty for non-compliance with the requirement to report suspicious transactions is a fine of up to 300,000 Baht.

102 Based on Thailand's implementation report pursuant to paragraphs 6 and 12 of UN Security Council Resolution 1455 (2003), submitted to the United Nations in June 2003. 
- However, the Money Laundering Act does not provide a legal basis for the authorities concerned, such as the Bank of Thailand or the Anti-Money Laundering Office, to freeze the transfer of funds or financial resources belonging to persons or entities suspected of committing or facilitating the commission of terrorist acts. This is because the object and purpose of the Money Laundering Act are to suppress the use of money for whatever purpose if the money is derived from certain specified unlawful activities. The Act was not intended to suppress the use of money deriving from lawful activities although such use is for unlawful purposes.

- Under the Money Exchange Control Act of 1942, all persons or legal entities that provide services for the transmission of money or valuables must be approved by the Ministry of Finance under the recommendation of the Bank of Thailand. Any persons or legal entities that provide such services in violation of the Act of 1942 shall be liable to a fine of up to 20,000 Baht or to imprisonment of up to three years or both.

- According to Notification No. 13 issued by the Bank of Thailand under the authority of the Money Exchange Controls Act of 1942, any person (except authorized banks, companies or persons) shall not buy, sell, lend, exchange or transfer foreign money or other foreign mediums of exchange without permission.

In the context of anti-terrorism, the Bank of Thailand has applied the following administrative measures to ensure that Thailand comply with the relevant Security Council Resolutions:

- Issued a circular requesting the Thai Bankers' Association, the Association of Finance Companies and the Foreign Banks' Association to distribute the UN Security Council's list of proscribed terrorists to all commercial banks and financial institutions. All commercial banks and financial institutions have been requested promptly to report their suspicions if any transactions that may be linked, or related, to terrorism, terrorist acts or terrorist organizations are carried out.

- Issued a notice to financial institutions regarding the correct practices in accepting a deposit for opening a bank account, and prohibits the use of an assumed name or alias. Financial institutions are required to follow the "Know Your Customer" Policy by having their customers identify themselves.

- In accordance with Thailand's existing exchange control law,

- The transfer of funds into or out of Thailand has to be reported to the Bank of Thailand; and

- Foreign exchange must be supported by relevant documents justifying the transactions in question. 
- Although circulars of the Bank of Thailand have no legal binding force, in practice all commercial banks and monetary institutions based in Thailand follow the guidelines in such circulars and report their actions to the Bank of Thailand.

No asset has been frozen in accordance with UN Security Council Resolution 1455 (2003). None of the financial assets or economic assets previously frozen are related to Usama Bin Laden or members of Al-Qaeda or the Taleban or associated individuals or entities, pursuant to UN Security Council Resolution 1452 (2002).

- In order to close the existing legal lacuna under Thai domestic laws, on 11 December 2001 the Council of State submitted to the Cabinet draft amendments to the Penal Code and to the Money Laundering Act.

- The draft amendment to the Penal Code defines the scope of terrorism and prescribes the act of terrorism as a serious offence under Thai criminal law. The proposed punishment ranges from a fine of between 200,000 and 1,000,000 Baht to the death sentence. Any person who threatens to commit such an offence or is an accomplice thereto would receive the same punishment as the principal perpetrator of the crime of terrorism. Persons engaging in various forms of attempted commission of the crime are subject to a lesser punishment, ranging from a fine of between 60,000 and 300,000 Baht to 3-15 years of imprisonment. Accomplices include persons or entities making funds or financial assets available to principal perpetrators. The draft amendment states that any person providing or procuring "force, arms, assets or any support for the commission of terrorism" is considered to be committing an act of terrorism. If found guilty, that person will be subject either to the death penalty, life imprisonment or imprisonment ranging from three years to 20 years, and shall also pay a fine of between 60,000 and 1,000,000 Baht.

- The thrust of the draft amendment to the Money Laundering Act is to make terrorist offences under the Penal Code as amended predicated offences under the Money Laundering Act, which will enable the Anti-Money Laundering Office to freeze the funds, financial assets and other economic resources of entities and persons who support terrorism.

- The Money Laundering Act as amended would empower the Transaction Committee, appointed by the Anti-Money Laundering Office, to examine a transaction or asset relating to the commission of an act of terrorism, as one of the predicated offences under the Act. According to Section 48, the Committee can withhold for a maximum of 90 days authorization for those transactions believed to be related to terrorism. The amended law will further enable the Committee to order the seizure or attachment of any property or asset found to be connected with the commission of any of the presently listed offences under the Money Laundering Act. 
- The two draft amendments to the Penal Code and the Anti-Money Laundering Act mentioned above have taken into account the requirements of the International Convention for the Suppression of the Financing of Terrorism of 1999, which Thailand signed on 18 December 2001.

\section{Travel Ban}

- Article 12(7) of the Immigration Act of 1979 stipulates that the competent Thai authority has the right to deny entry into the Kingdom of any person or persons whose conduct is deemed to be harmful to the peace and safety of the public or to national security, or who is/are being sought under a warrant of arrest issued by a competent authority of a foreign government.

- Intelligence and security agencies in Thailand have been on high alert since the 11 September 2001 incident. Tight measures are in place to inspect and monitor any movement of terrorists. A watch list of persons who have any connection with terrorist groups is shared among all agencies concerned so that they can cooperate to prevent suspects from entering the country.

- The immigration procedures start with the application for a visa at Thai Embassies and Consulates abroad. Thailand has reduced the number of countries eligible for visa exemption from 57 to 38 and the number of countries whose nationals may apply for a visa at the immigration checkpoint upon arrival has been reduced from 96 to 15. The Royal Thai Government has also introduced stricter visa application procedures for certain target groups. The requirement for visa application allows more time for authorities to check the identification of applicants to ensure that those who want to travel to Thailand are not on the watch list. Therefore, it is very important that the database be constantly updated.

- Terrorist suspects often travel with counterfeit documents and identification. The information received is often incomplete. Thai authorities may be informed of only the name of the suspected person without other relevant information, such as his/her last name or birth date. Incomplete information, such as lack of data on gender or passport number, makes it impossible for authorities concerned to include such information in the official watch list. In cases where there are many persons using the same name, which is not unusual for people of Arab origin, complete information is necessary to help confirm the true identification of the suspect.

- In an effort to enhance its capability to control the movement of people more effectively, the Immigration Bureau of Thailand has carried out the following actions: 
- The Bureau has installed a computerized system to monitor and collect information on incoming and outgoing passengers at all international airports.

- Black List or Watch List diskettes with names of terrorist groups proscribed by the United Nations are distributed to all 53 immigration border checkpoints as well as to the Thai Embassies and Consulates abroad to improve the efficiency of inspection of incoming and outgoing travellers. These diskettes are updated on a bi-monthly basis.

- The Bureau has installed a system linking all ports of entry with online data.

- The Bureau has also installed passport machines to check, prevent and arrest suspected terrorists and targeted persons in the Black List or Watch List, including persons who are under arrest warrants.

- Passport inspection equipment has also been installed at all international airports and key border checkpoints, such as the ones along the border with Malaysia.

\section{Legal Framework for International Cooperation}

- The Mutual Assistance in Criminal Matters Act of 1992 provides a broad framework for cooperation with other countries in criminal matters - taking testimony and statements of persons; providing documents, records and evidence for prosecution and search and seizure of assets. The thrust of the law is based on principles of double criminality and reciprocity that allow Thailand to extend assistance in criminal matters to virtually every country. The law is supplemented by the Treaties of Mutual Assistance in Criminal Matters that Thailand has concluded with five countries; namely, the United States, Canada, the United Kingdom, France and Norway.

- The Extradition Act of 1929 provides another channel of international judicial cooperation. As is the Act on Mutual Assistance in Criminal Matters, the main thrust of the Act of 1929 is also based on the two basic principles of double criminality and reciprocity. It is supplemented by 14 bilateral extradition treaties with friendly countries; namely, the United Kingdom, Belgium, Indonesia, the Philippines, the United States, the People's Republic of China, the Republic of Korea, Laos, Bangladesh, Cambodia, Malaysia, Fiji, Canada, and Australia.

- Thailand has also signed a Memorandum of Understanding on Counter Terrorism Cooperation with Australia and has acceded to the Agreement on Information Exchange and Establishment of Communication Procedures between Malaysia, Indonesia, the Philippines, and Cambodia. Besides, the Anti-Money Laundering Office has been a member of the EGMONT Group since 2000, thereby enabling the Office to have access to and exchange information with all the 57 members of the Group. 


\section{Arms Embargo}

Measures have been implemented to prevent the acquisition of conventional arms and weapons of mass destruction (WMD) by Osama Bin Laden, members of the Al-Qaeda organization and the Taleban, and other individuals, groups, undertakings and entities associated with them, along with Export Controls to prevent the above targets from obtaining the items and technology necessary for weapons development and production.

Measures to criminalize the violation of the arms embargo directed at Osama Bin Laden, members of Al-Qaeda organization and the Taleban, and other individuals, groups, undertakings and entities associated with them. Arms/arms broker licensing system/Safeguards of weapons and ammunition produced within Thailand

- The Ministry of Defence reports to the UN Register on Conventional Arms (UNSCR) through the Thai Ministry of Foreign Affairs on an annual basis on the import and export of seven kinds of conventional arms; namely, battle tanks, armoured combat vehicles, artillery systems, combat aircraft, attack helicopters, warships, missiles and missile launchers. The UNSCR controls the import and export of conventional arms that belong to its Member States.

- As a State Party to the Chemical Weapons Convention (CWC) of 1993, Thailand has complied with its obligations and is committed to the international and nondiscriminatory verification activities of the Organization for the Prohibition of Chemical Weapons (OPCW). The Royal Thai Government has already enacted legislation for the full implementation of the CWC. The Ministry of Industry has now concluded the Initial Declaration and is now expediting the process of its approval by the Cabinet, as required by the Constitution, before submitting it to the OPCW.

- $\quad$ Thailand is a State Party to the Nuclear Non-Proliferation Treaty (NPT) of 1968 and has its Safeguards Agreement with the International Atomic Energy Agency (IAEA). Thailand supports the recent proposals by the IAEA on the issue of protection against nuclear terrorism. Thailand's Office of Atom for Peace is accelerating the process to conclude the Additional Protocol with the IAEA.

- The proposed amendment to the Penal Code would punish any person who, inter alia, provides or procures arms or stockpiles weapons in order to commit a terrorist act.

- The relevant laws that regulate the domestic manufacture, sale, possession and disposition of weapons are:

- The Munitions of War Control Act of 1987, which prohibits a person from importing, procuring, manufacturing or possessing weapons except 
with the permission of the Permanent Secretary of the Department of Defence. The Act also states that permission shall not be given to any person who may cause any disturbance to the public peace.

- Under the Firearms, Ammunition, Explosive Articles and Fireworks and Imitation of Firearms Act 1974, a person shall not manufacture, purchase, possess, use, or import guns, bullets or explosives without permission from the firearms registrar. The permission shall not be given to any person who may cause any violence to the public peace.

- Furthermore, the Act on Export Control of Armaments and Materials of 1952 and the Decree on the Export Control of Armaments and Materials of 1992 subject an export or transshipment of weapons and explosives to the permission of the Minister of Defence or a person designated by the Minister, and to the following conditions of the export or transshipment:

- A foreign government shall request such export or transshipment pursuant to an agreement with the Royal Thai Government.

- The subjects of the export or transshipment shall be the Government's armaments and materials used in wartime, authorized by the Minister of Defence.

- The export or transshipment shall be undertaken publicly as a business authorized by the Minister of Defence.

- In the interest of enhancing Thailand's abilities to combat terrorism, on 19 August and 31 October 2002, the Ministry of Interior and the Ministry of Defence issued orders to various agencies to take all measures within their competence for strict compliance with the law by all handlers of firearms. These new measures include closer monitoring of sensitive materials by all provincial administrations. In addition, each province is entrusted with preparing a detailed report on the use of explosive materials on every first day of each month. The Permanent Secretary of the Interior has been authorized to approve all movements of sensitive materials across provincial borders. Armed military personnel must accompany movement of these materials.

- It is widely accepted that a large-scale terrorist attack requires extensive planning and includes the acquisition of explosive materials such as ammonium nitrate, TNT, power-gel and/or C4 as well as detonators. Taking the above into account, the Royal Thai Government has intensified its control and regulation of sensitive explosive materials and has tightened its surveillance of foreign persons that have irregular patterns of movement in Thailand.

- Imports and exports of prohibited and restricted goods are criminal offences and offenders are liable to punishment in accordance with the relevant laws governing the import and export of such goods. The Customs Act of 1926 also provides for punishment of those who submit false information on goods to be imported and exported. Offenders are liable to up to ten years' imprisonment. 
- Generally, customs officers check on spot goods to be exported and imported that are not subject to any restrictions or duties. Imports and exports of prohibited and restricted goods are subject to a thorough inspection. After 11 September 2001, Thailand has enforced more stringent measures for both imports and exports, especially those goods going to and coming from target countries, which are also thoroughly checked.

- In June 2003, Thailand and the United States signed a Declaration of Principles, paving the way for the implementation of the "Container Security Initiative" or the CSI. Under the CSI, Thai customs officers will work closely with their US counterparts to detect "suspect" containers, and stringent procedures for cargo shipment will be implemented.

- Thailand is also member of the Asia-Pacific Regional Intelligence Liaison Office, which has its headquarters in Tokyo. The Customs Services of 27 countries from Asia-Pacific and South Asia, including those of 18 Asian Regional Forum (ARF) countries, participate in this forum. It provides a good opportunity for customs officers in the region to share their experiences and intelligence. Past cooperation has focused on the issue of narcotic drugs, but it could be expanded to other issues relating to terrorism which has become a serious concern to the international community, such as illegal arms, chemicals and WMD. 